Novia Ariyanti, S.Si., M.Pd.

Nuril Lutvi Azizah, M.Si.

UMSIDA

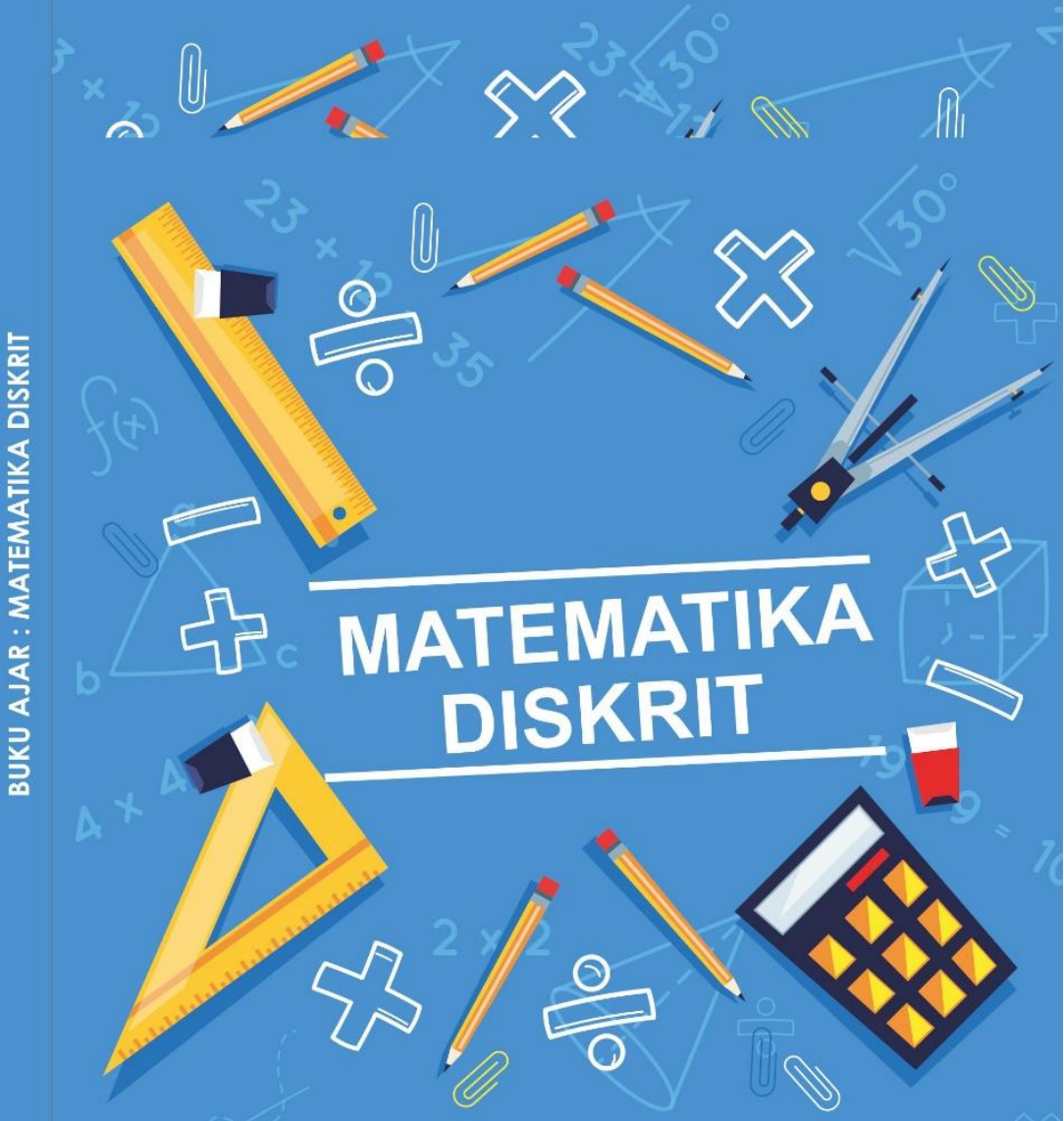

BUKU AJAR

UNIVERSITAS MUHAMMADIYAH SIDOARJO 


\title{
BUKU AJAR MATA KULIAH MATEMATIKA DISKRIT
}

\author{
Oleh \\ Novia Ariyanti, S.Si.,M.Pd. \\ Nuril Lutvi Azizah, S.Si., M.Si.
}

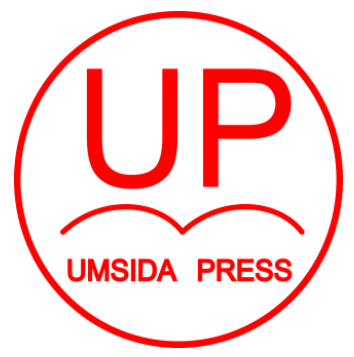

Diterbitkan oleh UMSIDA PRESS 2020 


\section{BUKU AJAR}

\section{MATEMATIKA DISKRIT}

\section{Penulis:}

Novia Ariyanti, S.Si., M.Pd.

Nuril Lutvi Azizah, S.Si., M.Pd.

\section{ISBN :}

978-623-6833-36-0

\section{Editor:}

Dr. Suprianto, S.Si, M.Si.

Mohammad Faizal Amir, M.Pd.

\section{Design Sampul dan Tata Letak:}

Mochamad Nashrulloh, S.Pd.

Amy Yoga Prajati, S.Kom.

Penerbit:

UMSIDA Press

Anggota IKAPI No. 218/Anggota Luar Biasa/JTI/2019

Anggota APPTI No.002 0181092017

Redaksi

Universitas Muhammadiyah Sidoarjo

Jl. Mojopahit No 666B

Sidoarjo, Jawa Timur

Cetakan Pertama, November 2020

CHak Cipta dilindungi undang undang

Dilarang memperbanyak karya tulis ini dengan sengaja, tanpa ijin tertulis dari penerbit. 


\section{KATA PENGANTAR}

Puji syukur kami panjatkan kehadirat Allah SWT, atas rahmat dan karunia-Nya Buku Ajar Matematika Diskrit dapat diselesaikan dengan baik dan tanpa halangan yang berarti. Shalawat dan salam selalu kami sampaikan kepada junjungan Nabi Muhammad SAW.

Tim penulis mengucapkan terimakasih kepada:

1. Dr. Hindarto, S.Kom., MT., Dekan Fakultas Sains dan Teknologi yang memberikan arahan dan motivasi kepada penulis dalam menyelesaikan buku ajar ini.

2. Arief Senja, S.Kom., M.Kom, Kaprodi Informatika yang telah memberikan dukungan untuk menyusun buku ajar ini.

3. Rekan-rekan dosen pengampu Mata Kuliah Matematika Diskrit di prodi Informatika yang telah berbagi pengalaman dalam mengampu mata kuliah tersebut.

Saran dan kritik sangat penulis harapkan untuk mewujudkan buku ajar Matematika Diskrit yang lebih baik dan tentunya sesuai dengan amanat peraturan yang berlaku. Terimakasih.

Tim Penulis 


\section{DAFTAR ISI}

HALAMAN SAMPUL.............................................. ii KATA PENGANTAR .............................................. iii

DAFTAR ISI ............................................................ iv

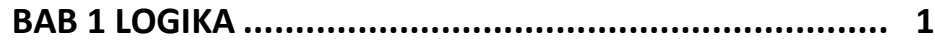

A. Proposisi ......................................................... 2

B. Tabel Kebenaran................................................. 4

C. Disjungsi Eksklusif............................................ 7

D. Hukum-hukum Logika Proposisi ........................... 8

E. Proposisi Bersyarat (Implikasi) .......................... 9

F. Varian Proposisi Bersyarat .................................10

G. Bikondisional (Bi-Implikasi) ...............................10

H. Inferensi..........................................................11

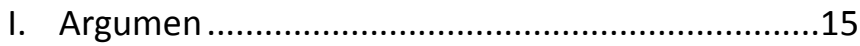

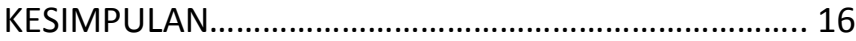

LATIHAN SOAL........................................................19

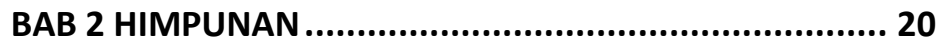

A. Definisi Himpunan .........................................21

B. Penyajian Himpunan............................................21

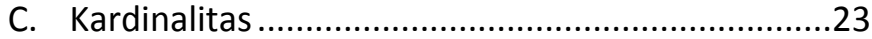

D. Himpunan Kosong ............................................24

E. Himpunan Bagian ............................................24

F. Himpunan yang Sama ........................................26

G. Himpunan yang Ekivalen ...................................26

H. Himpunan Saling Lepas....................................27

I. Himpunan Kuasa.................................................27

J. Operasi Terhadap Himpunan .............................28

K. Hukum-hukum Himpunan ..................................33

L. Prinsip Inklusi Eksklusi .........................................33

M. Pembuktian Proposisi Himpunan .........................36 


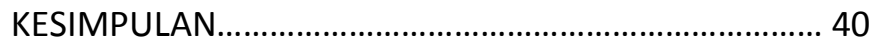

LATIHAN SOAL ..........................................................41

BAB 3 INDUKSI MATEMATIKA...................................... 43

A. Pernyataan Perihal Bilangan Bulat .......................44

B. Prinsip Induksi Sederhana .................................45

C. Prinsip Induksi Kuat .............................................51

D. Prinsip Induksi Secara Umum ...............................53

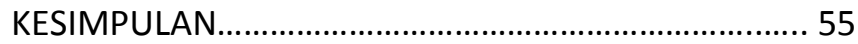

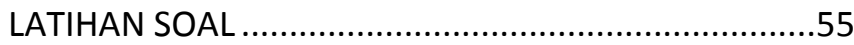

BAB 4 KOMBINATORIAL DAN PELUANG DISKRIT .......... 57

A. Kaidah Dasar Menghitung …................................59

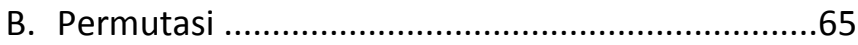

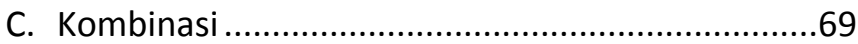

D. Kombinasi dengan Pengulangan .........................72

E. Peluang Diskrit...................................................74

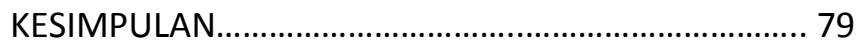

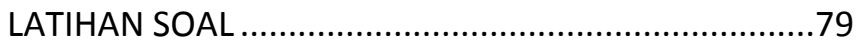

BAB 5 ALJABAR BOOLEAN .................................... 81

A. Definisi Aljabar Boolean ......................................82

B. Aljabar Boolean Dua Fungsi...............................83

C. Ekspresi Boolean ................................................85

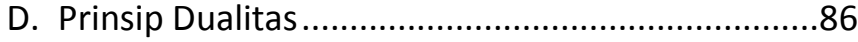

E. Hukum-hukum Aljabar Booelan ..........................87

F. Fungsi Boolean ............................................. 88

G. Penjumlahan dan Perkalian Dua Fungsi ...............89

H. Aplikasi Aljabar Boolean .....................................90

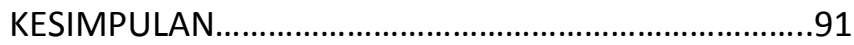

LATIHAN SOAL ..................................................92 
BAB 6 GRAPH ............................................... 93

A. Definisi Graph ................................................94

B. Jenis-Jenis Graph ...........................................95

C. Terminologi Dasar ..............................................96

D. Lintasan dan Sirkuit Euler ...................................100

E. Lintasan dan Sirkuit Hamilton ..............................100

F. Lintasan Terpendek .........................................101

G. Pewarnaan Graph..........................................101

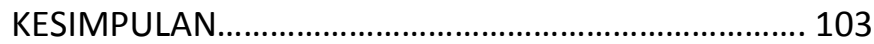

LATIHAN SOAL ......................................................105

DAFTAR PUSTAKA

BIODATA PENULIS 


\section{BATANG TUBUH DAN \\ SUB-CAPAIAN PEMBELAJARAN MATA KULIAH}

\begin{tabular}{|c|c|}
\hline BAB & Sub-Capaian Pembelajaran Mata Kuliah \\
\hline $\begin{array}{l}\text { BAB I } \\
\text { LOGIKA }\end{array}$ & $\begin{array}{l}\text { 1. Mahasiswa mampu memahami konsep logika } \\
\text { 2. Mahasiswa mampu memahami tabel-tabel } \\
\text { kebenaran proposisi } \\
\text { 3. Mahasiswa mampu mangaplikasikan logika dalam } \\
\text { bahasa pemrograman }\end{array}$ \\
\hline $\begin{array}{l}\text { BAB II } \\
\text { HIMPUNAN }\end{array}$ & $\begin{array}{l}\text { 1. Mahasiswa mampu memahami konsep teori } \\
\text { himpunan } \\
\text { 2. Mahasiswa mampu mengaplikasikan teori } \\
\text { himpunan dalam permasalahan }\end{array}$ \\
\hline $\begin{array}{l}\text { BAB III } \\
\text { INDUKSI } \\
\text { MATEMATIKA }\end{array}$ & $\begin{array}{l}\text { 1. Mahasiswa mampu memahami konsep induksi } \\
\text { matematika } \\
\text { 2. Mahasiswa mampu membuktikan suatu } \\
\begin{array}{l}\text { permasalahan dengan menggunakan induksi } \\
\text { matematika }\end{array}\end{array}$ \\
\hline $\begin{array}{l}\text { BAB IV } \\
\text { KOMBINATO } \\
\text { RIAL DAN } \\
\text { PELUANG } \\
\text { DISKRIT }\end{array}$ & $\begin{array}{l}\text { 1. Mahasiswa mampu memahami konsep peluang, } \\
\text { kombinasi dan peluang diskrit } \\
\text { 2. Mahasiswa mampu mengaplikasikan konsep } \\
\text { peluang, kombinasi dan peluang diskrit }\end{array}$ \\
\hline $\begin{array}{l}\text { BAB V } \\
\text { ALJABAR } \\
\text { BOOLEAN }\end{array}$ & $\begin{array}{l}\text { 1. Mahasiswa mampu memahami konsep aljabar } \\
\text { Boolean } \\
\text { 2. Mahasiswa mampu mengaplikasikan aljabar } \\
\text { Boolean }\end{array}$ \\
\hline $\begin{array}{l}\text { BAB VI } \\
\text { GRAPH }\end{array}$ & $\begin{array}{l}\text { 1. Mahasiswa mampu memahami konsep Graph } \\
\text { 2. Mahasiswa mampu mengaplikasikan Graph }\end{array}$ \\
\hline
\end{tabular}




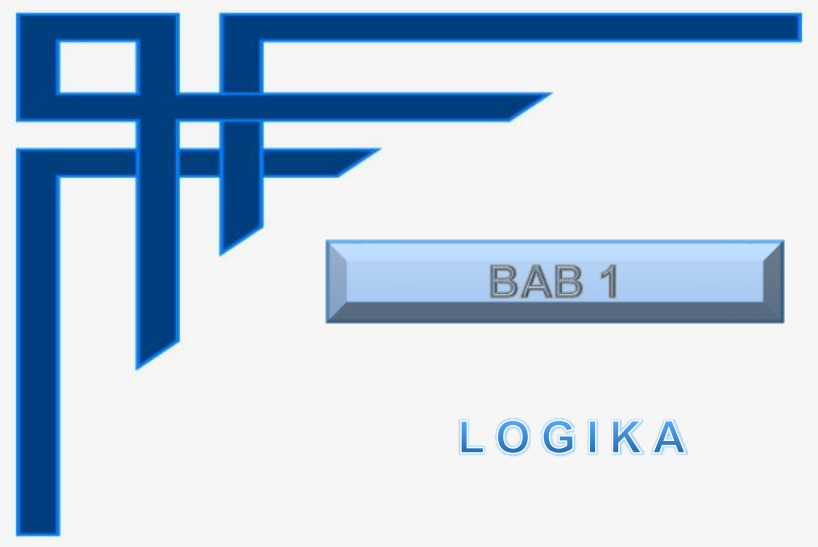

\section{CAPAIAN PEMBELAJARAN:}

1. Mahasiswa mampu memahami konsep logika

2. Mahasiswa mampu memahami tabel-tabel kebenaran proposisi

3. Mahasiswa mampu mangaplikasikan logika dalam bahasa pemrograman 
Logika Matematika atau Logika Simbol ialah logika yang menggunakan bahasa Matematika, yaitu dengan menggunakan lambang-lambang atau simbol- simbol.

\section{A. PROPOSISI}

Definisi 1.1. Proposisi adalah pernyataan yang bernilai benar (true) atau salah (false), tetapi tidak dapat bernilai keduanya. Kebenaran atau kesalahan dari sebuah pernyataan disebut nilai kebenaran.

Kalimat terbuka adalah kalimat yang belum tentu benar atau salah.

\section{Contoh 1.1:}

Perhatikan kalimat-kalimat di bawah ini:

1. Setelah bulan Januari adalah Februari

2. $2+3=5$

3. Sidoarjo adalah ibukota Indonesia

4. $5>2$

5. Gadis itu cantik

Semuanya merupakan proposisi. Proposisi 1, 2 dan 4 bernilai benar, tetapi proposisi 3 bernilai salah karena ibukota Indonesia adalah Jakarta. Sedangkan proposisi 5 adalah kalimat terbuka, tidak dapat langsung ditetapkan kebenarannya.

\section{Contoh 1.2:}

Perhatikan kalimat-kalimat di bawah ini:

1. Ambilkan buku itu!

2. Di universitas mana kamu kuliah?

3. $x+4=6$

4. $x<7$

Apakah kalimat-kalimat tersebut termasuk proposisi? Penyelesaian:

Bukan proposisi. Kalimat 1 adalah kalimat perintah, sedangkan kalimat 2 adalah kalimat tanya. Keduanya tidak bisa ditentukan kebenarannya. Kalimat 3 dan 4 adalah kalimat terbuka. 
Proposisi majemuk dibentuk dengan cara menggabungkan satu atau lebih proposisi. Proposisi yang berdiri sendiri atau tunggal disebut proposisi atomik. Proposisi majemuk dibentuk dari proposisi-proposisi atomik. Operator logika dasar yang digunakan untuk menggabungkan proposisi adalah dan (and), atau (or), dan tidak (not). Operator pertama dan kedua disebut operator biner karena menggabungkan dua proposisi, sedangkan operator ketiga disebut operator uner karena hanya membutuhkan satu proposisi.

Definisi 1.2. Misalkan $p$ dan $q$ adalah proposisi.

Konjungsi (conjunction) $p$ dan $q$ dinotasikan $p \wedge q$, adalah proposisi $\mathrm{p}$ dan $\mathrm{q}$.

Disjungsi (disjunction) p dan q dinotasikan p v q, adalah proposisi $\mathrm{p}$ atau $\mathrm{q}$.

Ingkaran (negation) dari p dinotasikan $\sim p$ adalah proposisi tidak $p$.

Contoh 1.3

Diketahui proposisi-proposisi berikut:

$p$ : Hari ini cerah

maka

q: Adek pergi ke taman

$p \wedge q \quad:$ Hari ini cerah dan adek pergi ke taman

$p \vee q$ : Hari ini cerah atau adek pergi ke taman

Contoh 1.4 $\sim p \quad$ : Hari ini tidak cerah

Diketahui proposisi-proposisi berikut:

$p$ : Gadis itu cantik

q : Gadis itu pintar

Nyatakan proposisi berikut dalam notasi simbolik:

a. Gadis itu cantik dan pintar

b. Gadis itu tidak cantik tapi pintar

c. Gadis itu tidak cantik maupun pintar 
d. Tidak benar bahwa gadis itu cantik atau tidak pintar

Penyelesaian:
a. $p \wedge q$
b. $\sim p \wedge q$ (kata "tetapi" bermakna sama dengan "dan ")
c. $\sim p \wedge \sim q$
d. $\sim(p \vee \sim q)$

\section{B. TABEL KEBENARAN}

Nilai kebenaran dari proposisi majemuk dinyatakan dari nilai kebenaran setiap proposisi anomiknya dan operator logika yang digunakan.

Definisi 1.3. Andaikan $p$ dan $q$ adalah proposisi majemuk.

a. Konjungsi $p \wedge q$ mempunyai nilai benar jika $p$ dan $q$ keduanya bernilai benar, selain itu bernilai salah

b. Disjungsi $p \vee q$ mempunyai nilai salah jika $p$ dan $q$ keduanya bernilai salah, selain itu bernilai benar

c. Negasi $p$ yaitu $\sim p$ mempunyai nilai benar jika $p$ salah, sebaliknya bernilai salah jika p benar

Tabel kebenaran adalah salah satu cara untuk menentukan nilai kebenaran suatu proposisi majemuk.. Tabel 1.1 tabel kebenaran untuk konjungsi, disjungsi dan ingkaran. Pada tabel tersebut $\mathrm{T}=$ True (benar), $\mathrm{F}=$ False (salah).

Tabel 1.1. Tabel kebenaran konjungsi, disjungsi dan ingkaran

\begin{tabular}{|c|c|c|c|c|}
\hline $\mathbf{P}$ & $\mathbf{q}$ & $\mathbf{p} \wedge \mathbf{q}$ & $\mathbf{p ~} \mathbf{V}$ & $\sim \mathbf{p}$ \\
$\mathbf{q}$ & \\
\hline $\mathrm{T}$ & $\mathrm{T}$ & $\mathbf{T}$ & $\mathbf{T}$ & $\mathbf{F}$ \\
\hline $\mathrm{T}$ & $\mathrm{F}$ & $\mathbf{F}$ & $\mathbf{T}$ & $\mathbf{F}$ \\
\hline $\mathrm{F}$ & $\mathrm{T}$ & $\mathbf{F}$ & $\mathbf{T}$ & $\mathbf{T}$ \\
\hline $\mathrm{F}$ & $\mathrm{F}$ & $\mathbf{F}$ & $\mathbf{F}$ & $\mathbf{T}$ \\
\hline
\end{tabular}

Contoh 1.5 
Jika $p, q$ dan $r$ adalah proposisi. Bentuklah tabel kebenaran dari ekspresi logika $(p \wedge q) \vee(\sim p \wedge r)$

Penyelesaian:

Ada 3 proposisi atomik dan setiap proposisi memiliki 2 kemungkinan nilai, jadi jumlah kombinasi dari semua proposisi adalah $2 \times 2 \times 2=8$.

\begin{tabular}{|c|c|c|c|c|c|c|}
\hline $\mathrm{P}$ & $\mathrm{Q}$ & $\mathrm{r}$ & $\mathrm{p} \wedge \mathrm{q}$ & $\sim \mathrm{p}$ & $\sim \mathrm{p} \wedge \mathrm{r}$ & $(\mathrm{p} \wedge \mathrm{q}) \vee(\sim \mathrm{p} \wedge \mathrm{r})$ \\
\hline $\mathrm{T}$ & $\mathrm{T}$ & $\mathrm{T}$ & $\mathrm{T}$ & $\mathrm{F}$ & $\mathrm{F}$ & $\mathrm{T}$ \\
\hline $\mathrm{T}$ & $\mathrm{T}$ & $\mathrm{F}$ & $\mathrm{T}$ & $\mathrm{F}$ & $\mathrm{F}$ & $\mathrm{T}$ \\
\hline $\mathrm{T}$ & $\mathrm{F}$ & $\mathrm{T}$ & $\mathrm{F}$ & $\mathrm{F}$ & $\mathrm{F}$ & $\mathrm{F}$ \\
\hline $\mathrm{T}$ & $\mathrm{F}$ & $\mathrm{F}$ & $\mathrm{F}$ & $\mathrm{F}$ & $\mathrm{F}$ & $\mathrm{F}$ \\
\hline $\mathrm{F}$ & $\mathrm{T}$ & $\mathrm{T}$ & $\mathrm{F}$ & $\mathrm{T}$ & $\mathrm{T}$ & $\mathrm{T}$ \\
\hline $\mathrm{F}$ & $\mathrm{T}$ & $\mathrm{F}$ & $\mathrm{F}$ & $\mathrm{T}$ & $\mathrm{F}$ & $\mathrm{F}$ \\
\hline $\mathrm{F}$ & $\mathrm{F}$ & $\mathrm{T}$ & $\mathrm{F}$ & $\mathrm{T}$ & $\mathrm{T}$ & $\mathrm{T}$ \\
\hline $\mathrm{F}$ & $\mathrm{F}$ & $\mathrm{F}$ & $\mathrm{F}$ & $\mathrm{T}$ & $\mathrm{F}$ & $\mathrm{F}$ \\
\hline
\end{tabular}

Definisi 1.4. Suatu proposisi majemuk jika proposisi tersebut bernilai benar untuk semua kasus dikatakan Tautologi, sebaliknya jika proposisi tersebut bernilai salah untuk semua kasus maka dikatakan Kontradiksi.

\section{Contoh 1.6}

Misalkan $\mathrm{p}$ dan $\mathrm{q}$ adalah poposisi. Buktikan dengan tabel kebenaran bahwa

a. $(\sim p \vee \sim q) \vee p$ adalah tautologi

b. $(p \wedge q) \wedge \sim(p \vee q)$ adalah kontradiksi

Penyelesaian:

a. $p \vee \sim(p \wedge q)$ tautologi

\begin{tabular}{|c|c|c|c|c|c|}
\hline $\mathrm{P}$ & $\mathrm{q}$ & $\sim \mathrm{p}$ & $\sim \mathrm{q}$ & $\sim \mathrm{p} \mathrm{V} \sim \mathrm{q}$ & $(\sim \mathrm{p} \mathrm{V} \sim \mathrm{q}) \mathrm{V}$ \\
\hline $\mathrm{T}$ & $\mathrm{T}$ & $\mathrm{F}$ & $\mathrm{F}$ & $\mathrm{F}$ & $\mathbf{T}$ \\
\hline $\mathrm{T}$ & $\mathrm{F}$ & $\mathrm{F}$ & $\mathrm{T}$ & $\mathrm{T}$ & $\mathbf{T}$ \\
\hline $\mathrm{F}$ & $\mathrm{T}$ & $\mathrm{T}$ & $\mathrm{F}$ & $\mathrm{T}$ & $\mathbf{T}$ \\
\hline $\mathrm{F}$ & $\mathrm{F}$ & $\mathrm{T}$ & $\mathrm{T}$ & $\mathrm{T}$ & $\mathbf{T}$ \\
\hline
\end{tabular}

b. $\sim(p \vee q) \wedge(p \wedge q)$ kontradiksi 


\begin{tabular}{|c|c|c|c|c|c|}
\hline $\mathrm{P}$ & $\mathrm{q}$ & $\begin{array}{c}\mathrm{p} \vee \\
\mathrm{q}\end{array}$ & $\begin{array}{c}\sim(\mathrm{p} \vee \\
\mathrm{q})\end{array}$ & $\mathrm{p} \wedge \mathrm{q}$ & $\sim(\mathrm{p} \vee \mathrm{q}) \wedge(\mathrm{p} \wedge$ \\
$\mathrm{q})$
\end{tabular}

Definisi 1.5. Dua buah proposisi dikatakan ekivalen jika kedua proposisi tersebut mempunyai tabel kebenaran yang sama.

\section{Contoh 1.7}

Buktikan proposisi $\sim(p \wedge q$ ) dan proposisi $\sim p \vee \sim q$ adalah ekivalen dengan menggunakan tabel kebenaran!

Penyelesaian:

\begin{tabular}{|c|c|c|c|c|c|c|}
\hline $\mathrm{p}$ & $\mathrm{q}$ & $\sim \mathrm{p}$ & $\sim \mathrm{q}$ & $\sim \mathrm{p} \mathrm{V} \sim \mathrm{q}$ & $\mathrm{p} \wedge \mathrm{q}$ & $\sim(\mathrm{p} \wedge \mathrm{q})$ \\
\hline $\mathrm{T}$ & $\mathrm{T}$ & $\mathrm{F}$ & $\mathrm{F}$ & $\mathbf{F}$ & $\mathrm{T}$ & $\mathbf{F}$ \\
\hline $\mathrm{T}$ & $\mathrm{F}$ & $\mathrm{F}$ & $\mathrm{T}$ & $\mathbf{T}$ & $\mathrm{F}$ & $\mathbf{T}$ \\
\hline $\mathrm{F}$ & $\mathrm{T}$ & $\mathrm{T}$ & $\mathrm{F}$ & $\mathbf{T}$ & $\mathrm{F}$ & $\mathbf{T}$ \\
\hline $\mathrm{F}$ & $\mathrm{F}$ & $\mathrm{T}$ & $\mathrm{T}$ & $\mathbf{T}$ & $\mathrm{F}$ & $\mathbf{T}$ \\
\hline
\end{tabular}

Terbukti.

\section{DISJUNGSI EKSKLUSIF}

Definisi 1.6. Disjungsi eksklusif proposisi $p$ dan proposisi $\mathrm{q}$ adalah proposisi bernilai benar jika hanya salah satu yang benar, selain itu bernilai salah. Disjungsi eksklusif dinotasikan $\mathrm{p} \oplus \mathrm{q}$.

Sebagai contoh, pernyataan:

$$
\text { "Juara } 1 \text { mendapat hadiah mobil atau uang" }
$$

Pernyataan itu akan menimbulkan penafsiran yang menjadi juara 1 dijanjikan mendapat hadiah. Hadiahnya adalah sebuah mobil, jika juara 1 tidak menginginkan mobil, panitia menggantinya dengan senilai uang.

Tabel 1.2. Tabel kebenaran disjungsi eksklusif

\begin{tabular}{|c|c|c|}
\hline $\mathrm{P}$ & $\mathrm{q}$ & $\begin{array}{c}\mathrm{p} \oplus \\
\mathrm{q}\end{array}$ \\
\hline $\mathrm{T}$ & $\mathrm{T}$ & $\mathbf{F}$ \\
\hline $\mathrm{T}$ & $\mathrm{F}$ & $\mathbf{T}$ \\
\hline
\end{tabular}




\begin{tabular}{|c|c|c|}
\hline $\mathrm{F}$ & $\mathrm{T}$ & $\mathbf{T}$ \\
\hline $\mathrm{F}$ & $\mathrm{F}$ & $\mathbf{F}$ \\
\hline
\end{tabular}

\section{HUKUM-HUKUM LOGIKA PROPOSISI}

Hukum Logika Proposisi adalah suatu hubungan ekivalensi logika yang memenuhi sifat-sifat dalam beberapa aturan atau hukum.

Tabel 1.3. Hukum-hukum Logika Proposisi

\begin{tabular}{|c|c|c|}
\hline 1. & Hukum Identitas & $\begin{array}{ll}\text { i. } & p \vee F \equiv p \\
\text { ii. } & p \wedge T \equiv p\end{array}$ \\
\hline 2. & Hukum Null/Dominasi & $\begin{array}{ll}\text { i. } & p \wedge F \equiv F \\
\text { ii. } & p \vee T \equiv T\end{array}$ \\
\hline 3. & Hukum Negasi & $\begin{array}{ll}\text { i. } & p \vee \sim p \equiv T \\
\text { ii. } & p \wedge \sim p \equiv F\end{array}$ \\
\hline 4. & Hukum Idempoten & $\begin{array}{cl}\text { i. } & p \vee p \equiv p \\
\text { ii. } & p \wedge p \equiv p\end{array}$ \\
\hline 5. & Hukum Involusi & $\sim(\sim p) \equiv p$ \\
\hline 6. & Hukum Penyerapan & $\begin{array}{cl}\text { i. } & p \vee(p \wedge q) \equiv p \\
\text { ii. } & p \wedge(p \vee q) \equiv p\end{array}$ \\
\hline 7. & Hukum Komutatif & $\begin{array}{ll}\text { i. } & p \vee q \equiv q \vee p \\
\text { ii. } & p \wedge q \equiv q \wedge p\end{array}$ \\
\hline 8. & Hukum Asosiatif & $\begin{array}{ll}\text { i. } & p \vee(q \vee r) \equiv(p \vee q) \vee r \\
\text { ii. } & p \wedge(q \wedge r) \equiv(p \wedge q) \wedge r\end{array}$ \\
\hline 9. & Hukum Distributif & $\begin{array}{ll}\text { i. } & p \vee(q \wedge r) \equiv(p \vee q) \wedge(p \vee \\
& q)\end{array}$ \\
\hline
\end{tabular}




\begin{tabular}{|l|l|ll|}
\hline & & ii. & $p \wedge(q \vee r) \equiv(p \wedge q) \vee(p \wedge$ \\
& & \\
& & & \\
\hline 10. & Hukum De Morgan & i. & $\sim(c) \equiv \sim p \vee \sim q$ \\
& & ii. & $\sim(p \vee q) \equiv \sim p \wedge \sim q$ \\
\hline
\end{tabular}

\section{E. IMPLIKASI (PROPOSISI BERSYARAT)}

Definisi 1.7. Proposisi bersyarat (implikasi) "jika $p$, maka q" dan dinotasikan $\mathrm{p} \rightarrow \mathrm{q}$. Proposisi $\mathrm{p}$ sebagai hipotesis (premis) dan proposisi q sebagai konklusi.

Sebagai contoh :

Jika, $\quad p$ : Kirani adalah mahasiswa yang rajin

$\mathrm{q}$ : Kirani lulus kuliah tepat waktu

$p \rightarrow q$ : Jika Kirani adalah mahasiswa yang rajin maka ia lulus kuliah tepat waktu

Jadi, bila kita tahu bahwa Kirani mahasiswa yang rajin, kita juga tahu bahwa ia lulus kuliah tepat waktu. Berdasarkan pernyataan diatas, maka untuk menunjukkan bahwa Kirani lulus kuliah tepat waktu adalah cukup dengan menunjukkan bahwa Kirani mahasiwa yang rajin atau Kirani mahasiwa yang rajin merupakan syarat cukup untuk ia lulus kuliah tepat waktu. Sedangkan untuk menunjukkan bahwa Kirani adalah mahasiswa yang rajin adalah perlu dengan menunjukkan Kirani lulus kuliah tepat waktu atau Kirani lulus kuliah tepat waktu merupakan syarat perlu bagi Kirani mahasiswa yang rajin. Karena Kirani dapat lulus kuliah tepat waktu hanya bila ia mahasiwa yang rajin.

Tabel 1.4. Tabel kebenaran implikasi

\begin{tabular}{|c|c|c|}
\hline$p$ & $q$ & $p \rightarrow q$ \\
\hline$T$ & $T$ & $T$ \\
\hline$T$ & $F$ & $\mathbf{F}$ \\
\hline$F$ & $T$ & $T$ \\
\hline$F$ & $F$ & $T$ \\
\hline
\end{tabular}




\section{F. VARIAN PROPOSISI BERSYARAT}

Varian berbeda dari proposisi bersyarat yaitu:

Konvers (kebalikan) : $q \rightarrow p$

Invers

Kontraposisi

$: \sim p \rightarrow \sim q$

$: \sim q \rightarrow \sim p$

Tabel 1.5. Tabel kebenaran implikasi, konvers, invers, dan kontraposisi

\begin{tabular}{|c|c|c|c|c|c|c|c|}
\hline $\mathrm{P}$ & $\mathrm{Q}$ & $\sim \mathrm{p}$ & $\sim \mathrm{q}$ & $\begin{array}{c}\text { Implika } \\
\mathrm{si} \\
\mathrm{p} \rightarrow \mathrm{q}\end{array}$ & $\begin{array}{c}\text { Konver } \\
\mathrm{s} \\
\mathrm{q} \rightarrow \mathrm{p}\end{array}$ & $\begin{array}{c}\text { Invers } \\
\sim \mathrm{p} \rightarrow \sim \mathrm{q}\end{array}$ & $\begin{array}{c}\text { Kontraposi } \\
\text { si } \\
\sim \mathrm{q} \rightarrow \sim \mathrm{p}\end{array}$ \\
\hline $\mathrm{T}$ & $\mathrm{T}$ & $\mathrm{F}$ & $\mathrm{F}$ & $\mathrm{T}$ & $\mathrm{T}$ & $\mathrm{T}$ & $\mathrm{T}$ \\
\hline $\mathrm{T}$ & $\mathrm{F}$ & $\mathrm{F}$ & $\mathrm{T}$ & $\mathrm{F}$ & $\mathrm{T}$ & $\mathrm{T}$ & $\mathrm{F}$ \\
\hline $\mathrm{F}$ & $\mathrm{T}$ & $\mathrm{T}$ & $\mathrm{F}$ & $\mathrm{T}$ & $\mathrm{F}$ & $\mathrm{F}$ & $\mathrm{T}$ \\
\hline $\mathrm{F}$ & $\mathrm{F}$ & $\mathrm{T}$ & $\mathrm{T}$ & $\mathrm{T}$ & $\mathrm{T}$ & $\mathrm{T}$ & $\mathrm{T}$ \\
\hline
\end{tabular}

\section{Contoh 1.8}

Ubahlah proposisi bersyarat berikut menjadi konvers, invers dan kontraposisi dari pernyataan berikut: "Jika Sarah memiliki rumah, maka ia seorang pekerja keras" Penyelesaian:

Konvers : Jika Sarah seorang pekerja keras, maka ia memiliki rumah

Invers : Jika Sarah tidak memiliki rumah, maka ia bukan pekerja keras

Kontraposisi: Jika Sarah bukan seorang pekerja keras, maka ia tidak mempunyai rumah

\section{G. BIKONDISIONAL}

Definisi 1.8. Andaikan $p$ dan $q$ adalah proposisi. Proposisi bikondisional adalah "p jika dan hanya jika q" dan dinotasikan $\mathrm{p} \leftrightarrow \mathrm{q}$.

Tabel 1.6. Tabel kebenaran bikondisional

\begin{tabular}{|c|c|c|}
\hline$p$ & $q$ & $p \leftrightarrow q$ \\
\hline$T$ & $T$ & $T$ \\
\hline$T$ & $F$ & $F$ \\
\hline
\end{tabular}




\begin{tabular}{|l|l|l|}
\hline $\mathrm{F}$ & $\mathrm{T}$ & $\mathrm{F}$ \\
\hline $\mathrm{F}$ & $\mathrm{F}$ & $\mathrm{T}$ \\
\hline
\end{tabular}

Bikondisional $p \leftrightarrow q$ dikatakan ekivalen atau memiliki tabel kebenaran yang sama dengan $(p \rightarrow q) \wedge(q \rightarrow p)$. Dengan kata lain pernyataan "p jika dan hanya jika q" dapat dibaca "Jika p maka q dan jika q maka p". Keekivalenan tersebut ditunjukkan pada Tabel 1.7.

Tabel 1.7. Tabel $(p \leftrightarrow q) \equiv(p \rightarrow q) \wedge(q \rightarrow p)$

\begin{tabular}{|c|c|c|c|c|c|}
\hline$P$ & $\mathrm{Q}$ & $\mathrm{p} \leftrightarrow \mathrm{q}$ & $\mathrm{p} \rightarrow \mathrm{q}$ & $\mathrm{q} \rightarrow \mathrm{p}$ & $(\mathrm{p} \rightarrow \mathrm{q}) \wedge(\mathrm{q} \rightarrow \mathrm{p})$ \\
\hline $\mathrm{T}$ & $\mathrm{T}$ & $\mathbf{T}$ & $\mathrm{T}$ & $\mathrm{T}$ & $\mathbf{T}$ \\
\hline $\mathrm{T}$ & $\mathrm{F}$ & $\mathbf{F}$ & $\mathrm{F}$ & $\mathrm{T}$ & $\mathbf{F}$ \\
\hline $\mathrm{F}$ & $\mathrm{T}$ & $\mathbf{F}$ & $\mathrm{T}$ & $\mathrm{F}$ & $\mathbf{F}$ \\
\hline $\mathrm{F}$ & $\mathrm{F}$ & $\mathbf{T}$ & $\mathrm{T}$ & $\mathrm{T}$ & $\mathbf{T}$ \\
\hline
\end{tabular}

\section{H. INFERENSI}

Inferensi adalah suatu proses dalam penarikan kesimpulan dari beberapa proposisi. Ada beberapa kaidah inferensi, diantaranya sebagai berikut:

1. Modus Ponen

Kaidah modus ponen

$$
\begin{aligned}
& \mathrm{p} \rightarrow \mathrm{q} \\
& \mathrm{p} \\
& \therefore \quad \mathrm{q}
\end{aligned}
$$

Contoh 1.9

Misalkan diketahui:

Premis 1: Jika bilangan itu ganjil, maka kuadratnya juga ganjil

Premis 2: 3 bilangan ganjil

Sehingga inferensinya adalah:

Jika bilangan itu ganjil, maka kuadratnya juga ganjil 3 bilangan ganjil.

$\therefore$ kuadrat dari 3 juga ganjil"

adalah benar.

\section{Modus Tollen}

Kaidah modus tollens 


$$
\begin{gathered}
p \rightarrow q \\
\quad \sim q \\
\hline \therefore \quad \sim p
\end{gathered}
$$

Contoh 1.10

Diketahui:

Premis 1: Jika $n$ bilangan genap, maka $n^{2}$ bernilai genap

Premis 2: $n^{2}$ bernilai ganjil

Sehingga inferensinya adalah:

Jika $\mathrm{n}$ bilangan genap, maka $\mathrm{n}^{2}$ bernilai genap

$\therefore \mathrm{n}$ bukan bilangan genap

$\mathrm{n}^{2}$ bernilai ganjil

adalah benar.

\section{Silogisme Hipotesis}

Kaidah silogisme

$p \rightarrow q$

$q \rightarrow r$

$$
\therefore p \rightarrow r
$$

Contoh 1.11

Diketahui:

Premis 1: Jika saya belajar sungguh-sungguh, maka nilai saya bagus

Premis 2: Jika nilai saya bagus, maka orang tua saya senang

Maka menurut silogisme hipotesis, inferensinya sebagai berikut:

bagus

Jika saya belajar sungguh-sungguh, maka nilai saya

Jika nilai saya bagus, maka orang tua saya senang

$\therefore$ Jika saya belajar sungguh-sungguh, maka orang tua saya senang

adalah benar.

\section{Silogisme Disjungtif}

Kaidah silogisme disjungtif

$\mathrm{p} \vee \mathrm{q}$

$\sim p$

$\therefore \mathrm{q}$ 
Contoh 1.12

Diketahui:

Premis 1: Sinta rajin kuliah atau ia menikah tahun ini

Premis 2: Sinta tidak rajin kuliah

Maka kaidah silogisme dijungtif dapat ditulis:

Sinta rajin kuliah atau ia menikah tahun ini

Sinta tidak rajin kuliah

$\therefore$ Sinta menikah tahun ini.

\section{Simplifikasi}

Kaidah simplifikasi

$p \wedge q$

$\therefore \mathrm{p}$

Contoh 1.13

Diketahui:

Premis 1: Doni adalah mahasiswa ITS dan UMSIDA

Penarikan kesimpulan dengan kaidah smplifikasi dapat ditulis:

Doni adalah mahasiswa ITS dan UMSIDA

$\therefore$ Doni adalah mahasiswa ITS

Simplifikasi berikut juga benar untuk:

Doni adalah mahasiswa ITS dan UMSIDA

$\therefore$ Doni adalah mahasiswa UMSIDA

Urutan proposisi dalam $\mathrm{p} \wedge \mathrm{q}$ tidak berpengaruh.

6. Penjumlahan

Kaidah penjumlahan

$\mathrm{p}$

$\therefore \mathrm{p} \vee \mathrm{q}$

Contoh 1.14

Diketahui:

Premis 1: Arya mengambil kuliah Aljabar Linier

Penarikan kesimpulan dengan kaidah penjumlahan dapat ditulis:

Arya mengambil kuliah Aljabar Linier 
$\therefore$ Arya mengambil kuliah Aljabar Linier atau mengulang kuliah Matematika Diskrit.

7. Konjungsi

Kaidah konjungsi

$\mathrm{p}$

q

$$
\therefore \mathrm{p} \wedge \mathrm{q}
$$

Contoh 1.15

Diketahui:

Premis 1: Arya mengambil kuliah Aljabar Linier

Premis 2: Arya mengulang kuliah Matematika Diskrit Penarikan kesimpulan dengan kaidah konjungsi dapat ditulis:

Arya mengambil kuliah Aljabar Linier

Arya mengulang kuliah Matematika Diskrit

$\therefore$ Arya mengambil kuliah Aljabar Linier dan mengulang kuliah Matematika Diskrit.

\section{ARGUMEN DAN METODE PENARIKAN KESIMPULAN}

Definisi 1.9. Suatu pernyataan dapat dikatakan valid jika konklusi (kesimpulan) benar apabila semua hipotesisnya benar, sebaliknya pernyataan dikatakan palsu (invalid) jika semua hipotesisnya benar tetapi ada konklusi (kesimpulan) salah.

Untuk menunjukkan kevalidan suatu argumen, yang harus dilakukan pertama kali adalah menulis argumen tersebut dalam bentuk simbol-simbol.

\section{Contoh 1.16}

Roy kuliah jurusan Informatika atau Manajemen

Roy tidak kuliah jurusan Informatika

Jadi, Roy kuliah jurusan Manajemen

Misal:

$\mathrm{p}$ : Roy kuliah jurusan Informatika

q : Roy kuliah jurusan Manajemen

maka argumen diatas mempunyai simbol sebagai berikut:

$$
\begin{aligned}
& p \vee q \\
& \sim p
\end{aligned}
$$


Langkah berikutnya mengubah argumen tersebut menjadi pernyataan kondisional yang berkoresponden yaitu dengan cara mengkonjungsikan premis-premis, lalu hasilnya diimplikasikan dengan konklusi. Sehingga menjadi:

$$
((p \vee q) \wedge \sim p) \rightarrow q
$$

Untuk menguji kevalidan pernyataan kondisional tersebut dengan menggunakan tabek kebenaran. Jika tabel kebenaran bernilai benar semua atau tautologi, maka argumen tersebut dikatakan valid. Jika tidak, maka argumen tersebut dikatakan tidak valid. Tabel kebenaran untuk argumen diatas sebagai berikut:

\begin{tabular}{|c|c|c|c|c|c|}
\hline $\mathrm{P}$ & $\mathrm{Q}$ & $\sim \mathrm{p}$ & $\mathrm{p} \vee \mathrm{q}$ & $(\mathrm{p} \vee \mathrm{q}) \wedge \sim \mathrm{p}$ & $(\mathrm{p} \vee \mathrm{q}) \wedge \sim \mathrm{p}) \rightarrow \mathrm{q}$ \\
\hline $\mathrm{T}$ & $\mathrm{T}$ & $\mathrm{F}$ & $\mathrm{T}$ & $\mathrm{F}$ & $\mathbf{T}$ \\
\hline $\mathrm{T}$ & $\mathrm{F}$ & $\mathrm{F}$ & $\mathrm{T}$ & $\mathrm{F}$ & $\mathbf{T}$ \\
\hline $\mathrm{F}$ & $\mathrm{T}$ & $\mathrm{T}$ & $\mathrm{T}$ & $\mathrm{F}$ & $\mathbf{T}$ \\
\hline $\mathrm{F}$ & $\mathrm{F}$ & $\mathrm{T}$ & $\mathrm{F}$ & $\mathrm{F}$ & $\mathbf{T}$ \\
\hline
\end{tabular}

Berdasarkan tabel kebenaran yang dihasilkan yaitu tautologl, maka argumen diatas valid.

\section{KESIMPULAN}

1. Proposisi adalah pernyataan yang bernilai benar (true) atau salah (false), tetapi tidak dapat sekaligus keduanya. Kebenaran atau kesalahan dari sebuah kalimat disebut nilai kebenaran.

2. Kalimat terbuka adalah kalimat yang belum tentu benar atau salah.

3. Konjungsi (conjunction) $\mathrm{p}$ dan $\mathrm{q}$ dinyatakan dengan notasi $\mathrm{p} \wedge$ $q$, adalah proposisi $p$ dan $q$. 
4. Disjungsi (disjunction) $\mathrm{p}$ dan $\mathrm{q}$ dinyatakn dengan notasi $\mathrm{p} \vee \mathrm{q}$, adalah proposisi $p$ atau $q$.

5. Ingkaran (negation) dari $p$ dinyatakan dengan notasi $\sim p$ adalah proposisi tidak $\mathrm{p}$.

6. Konjungsi $\mathrm{p} \wedge \mathrm{q}$ mempunyai nilai benar jika $\mathrm{p}$ dan $\mathrm{q}$ keduanya bernilai benar, selain itu bernilai salah

7. Disjungsi $p \vee q$ mempunyai nilai salah jika $p$ dan $q$ keduanya bernilai salah, selain itu bernilai benar

8. Negasi $p$ yaitu $\sim p$ mempunyai nilai benar jika $p$ salah, sebaliknya bernilai salah jika p benar

9. Suatu proposisi majemuk jika proposisi tersebut bernilai benar untuk semua kasus dikatakan Tautologi, sebaliknya jika proposisi tersebut bernilai salah untuk semua kasus maka dikatakan Kontradiksi.

10. Dua buah proposisi dikatakan ekivalen jika kedua proposisi tersebut mempunyai tabel kebenaran yang sama.

11. Disjungsi eksklusif $p$ dan $q$ adalah proposisi bernilai benar jika hanya salah satu yang benar, selain itu bernilai salah. Disjungsi eksklusif dinotasikan $\mathrm{p} \oplus \mathrm{q}$.

12. Proposisi bersyarat (implikasi) "jika $p$, maka q" dan dinotasikan dengan $\mathrm{p} \rightarrow \mathrm{q}$.

13. Konvers (kebalikan): $q \rightarrow p$

14. Invers

$$
: \sim p \rightarrow \sim q
$$

15. Kontraposisi

$$
: \sim q \rightarrow \sim p
$$

16. Proposisi bikondisional adalah "p jika dan hanya jika q" dan dinotasikan dengan $\mathrm{p} \leftrightarrow \mathrm{q}$.

17. Modus Ponen

$$
\begin{aligned}
& p \rightarrow q \\
\therefore \quad & p
\end{aligned}
$$


18. Modus Tollens

$$
\begin{aligned}
& p \rightarrow q \\
& \therefore \frac{\sim q}{\sim p}
\end{aligned}
$$

19. Silogisme

$$
\begin{aligned}
& p \rightarrow q \\
& q \rightarrow \frac{r}{\therefore \quad p \rightarrow r}
\end{aligned}
$$

20. Silogisme disjungtif

$$
\begin{aligned}
& p \vee q \\
& \therefore q p
\end{aligned}
$$

21. Simplifikasi

$$
\mathrm{p} \wedge \mathrm{q}
$$$$
\therefore \mathrm{p}
$$

22. Penjumlahan

$$
\therefore \quad p \vee q
$$

23. Konjungsi

$$
\begin{gathered}
\mathrm{q} \\
\therefore \quad p \wedge q
\end{gathered}
$$

24. Suatu argumen dapat dikatakan valid jika konklusi (kesimpulan) benar apabila semua hipotesisnya benar, sebaliknya argumen dikatakan palsu (invalid) jika semua hipotesisnya benar tetapi ada konklusi (kesimpulan) salah. 


\section{LATIHAN SOAL}

1. Mana yang proposisi dan cari nilai kebenaran dari pernyataan yang merupakan proposisi!

a. $4+17=20$

b. Untuk beberapa bilangan bulat $n, 100=n .25$

c. $m+n=n+m$ untuk setiap pasangan bilangan riil $m$ dan $n$

d. Ambil 4 buah buku di dalam lemari

2. Misalkan $p$ adalah "Joni menguasai Java”, q adalah "Joni menguasai Corel" dan $r$ adalah "Joni menguasai C++". Ubah kalimat majemuk menjadi notasi simbolik:

a. Joni menguasai Java atau Corel, atau dia tidak menguasai $\mathrm{C}_{++}$dan Java

b. Tidak benar Joni menguasai Java atau Corel

3. Tuliskan tabel kebenaran untuk setiap proposisi berikut:

a. $(p \vee q) \wedge \sim p$

b. $\sim(p \wedge q) \vee(\sim q \vee r)$

c. $(\sim p \vee \sim q) \vee p$

d. $(\sim q \rightarrow p) \rightarrow(p \rightarrow \sim q)$

4. Nyatakan ingkaran, invers dan konvers dari implikasi berikut:

a. Saya masuk kuliah bilamana ada ujian

b. Dia pergi kuliah bilamana hari ini tidak hujan atau mendung

5. Periksa kesahihan argumen berikut:

Terlambat makan lebih baik daripada tidak Tidak ada yang lebih baik daripada sakit maag

$\therefore$ Terlambat makan lebih baik daripada sakit maag 


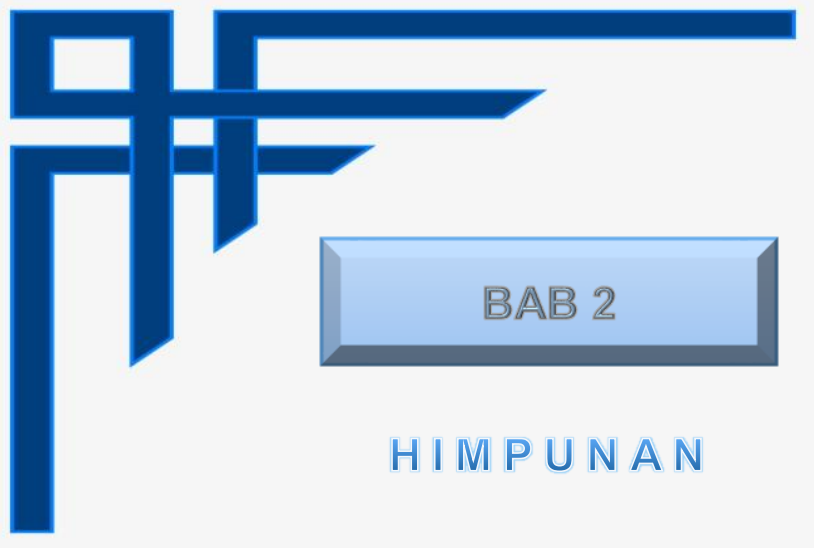

CAPAIAN PEMBELAJARAN:

1. Mahasiswa mampu memahami konsep teori himpunan

2. Mahasiswa mampu mengaplikasikan teori himpunan dalam permasalahan sehari-hari 
Berbicara tentang objek diskrit, sering dihadapkan pada situasi yang berhubungan dengan sekumpulan objek dalam suatu kelompok. Himpunan digunakan untuk mengelompokkan objek secara bersama.

\section{A. DEFINISI HIMPUNAN}

Definisi 2.1. Himpunan adalah kumpulan objek-objek yang berbeda.

Objek yang terdapat dalam himpunan disebut elemen, unsur atau anggota.

Contoh 2.1

1. A adalah himpunan nama kota di Jawa Tengah.

Anggota himpunan A adalah Purwokerto, Semarang, Kebumen, ...

2. B adalah himpunan bilangan bulat lebih dari -3 .

Anggota himpunan $B$ adalah bilangan $-2,-1,0,1,2,3, \ldots$

\section{B. PENYAJIAN HIMPUNAN}

Penyajian himpunan ada empat cara yaitu sebagai berikut:

\section{Enumerasi}

Semua anggota disebutkan dan diletakkan dia dalam sepasang kurung kurawal dan antara anggota yang satu dan yang lain dipisahkan tanda koma.

Contoh 2.2

$$
\begin{aligned}
A & =\{\text { apel, mangga, jeruk }\} \\
\mathrm{B} & =\{1,2,3,4,5,6\}
\end{aligned}
$$

\section{Simbol-simbol baku}

Penyajian himpunan dinotasikan simbol-simbol yang baku. Simbol-simbol baku yang berbentuk huruf tebal yang biasa digunakan untuk menyebut himpunan yang sering digunakan, yaitu antara lain:

$$
\begin{aligned}
& \mathbf{R}=\text { himpunan bilangan riil } \\
& \mathbf{Q}=\text { himpunan bilangan rasional }
\end{aligned}
$$




$$
\begin{aligned}
& \mathbf{Z}=\text { himpunan bilangan bulat } \\
& \mathbf{P}=\text { himpunan bilangan bulat positif } \\
& \mathbf{N}=\text { himpunan bilangan asli } \\
& \mathbf{C}=\text { himpunan bilangan kompleks }
\end{aligned}
$$

Himpunan semesta biasanya dilambangkan dengan "U" (Universal) atau "S" (Semesta) yang berarti himpunan yang memuat semua anggota yang dibicarakan atau kata lainya himpunan dari objek yang sedang dibicarakan.

\section{Notasi Pembentuk Himpunan}

Dengan cara penyajian ini, himpunan dinyatakan dengan mendeskripsikan syarat yang harus dipenuhi oleh anggotanya.

Notasi: $\{x \mid$ syarat yang harus dipenuhi oleh $x\}$ Contoh 2.3

Nyatakan dengan notasi himpunan dengan menuliskan tiap-tiap anggotanya dan sifat-sifatnya himpunan berikut ini :

A adalah himpunan bilangan asli antara 1 dan 6 Penyelesaian :

A adalah himpunan bilangan asli antara 1 dan 6

Dengan menulis tiap-tiap anggotanya $A=\{2,3,4,5\}$

Dengan menulis sifat-sifatnya $A=\{x \mid 1<x<6, x \in N\}$

\section{Diagram Venn}

Diagram Venn yaitu segi empat dimana ada himpunan semesta dan himpunan yang lain digambarkan sebagai lingkaran di dalam segi empat tersebut.

Contoh 2.4

Misalkan $U=\{1,2, \ldots, 7,8\}, A=\{2,4,5\}$ dan $B=\{2,5$, $6,8\}$. 
Sajikan himpunan-himpunan tersebut daloam diagram venn!

Penyelesaian:

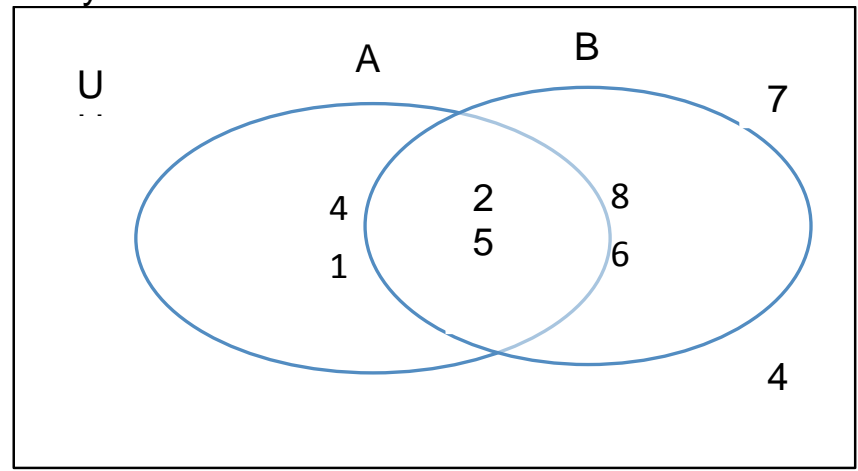

Gambar 2.1 Diagram venn

\section{KARDINALITAS}

Definisi 2.2. Kardinalitas suatu himpunan adalah banyaknya anggota himpunan tersebut yang dinyatakan dengan bilangan bulat positif.

Misalkan $A$ adalah himpunan berhingga, maka jumlah elemen berbeda di dalam $A$ disebut kardinal dari himpunan $A$. Notasi: $n(A)$ atau $|A|$

\section{Contoh 2.5}

Di bawah ini adalah contoh-contoh himpunan berhingga:

a. $A=\{x \mid x$ merupakan bilangan prima yang lebih kecil dari 10$\}$ $A=\{2,3,5,7\}$

$n(A)=4$

b. $B=\{x \mid x$ adalah huruf vocal $\}$

$B=\{a, i, u, e, o\}$

$n(B)=5$

D. HIMPUNAN KOSONG (NULLSET)

Definisi 2.3. Himpunan yang tidak memiliki anggota atau 
himpunan dengan kardinalnya 0 disebut himpunan kosong.

Himpunan kosong adalah himpunan bagian dari setiap himpunan.

Himpunan kosong tidak boleh dinyatakan dengan $\{0\}$ karena $\{0\} \neq\{\}$

\section{Contoh 2.6}

a. $A=\{x \mid x$ adalah bilangan asli kurang dari 1$\}$

$A=\{\}$

$$
n(\mathrm{~A})=0
$$

b. $B=\{$ orang laki-laki hamil $\}$

$B=\{\}$

$$
n(\mathrm{~B})=0
$$

\section{E. HIMPUNAN BAGIAN (SUBSET)}

Definisi 2.4. Himpunan A dikatakan himpunan bagian (subset) dari himpunan $B$ jika dan hanya jika setiap elemen A merupakan elemen dari B. dalam hal ini, B dikatakan superset dari $A$.

Notasi: $A \subseteq B$

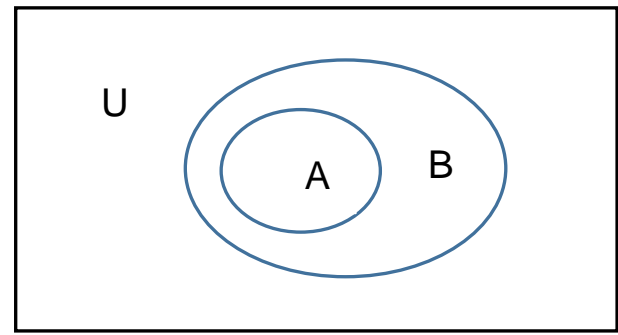

Gambar 2.2 Diagram Venn untuk $A \subseteq B$

\section{Contoh 2.7}

a. $A=\{0,2,3,7,8,9\}$ dan $B=\{0,9\}$ maka $B \subseteq A$

b. $\quad N \subseteq Z \subseteq R \subseteq C$ 
Teorema 2.1. Untuk sebarang himpunan A berlaku hal-hal sebagai berikut:

a) A adalah himpunan bagian dari $A$ itu sendiri (yaitu, $A \subseteq A$ )

b) Himpunan kosong merupakan himpunan bagian dari $A$ $(\varnothing \subseteq A)$

c) Jika $\mathrm{A} \subseteq \mathrm{B}$ dan $\mathrm{B} \subseteq \mathrm{C}$, maka $\mathrm{A} \subseteq \mathrm{C}$

Bukti:

Untuk teorema 2.1 (a) mudah ditunjukkan karena elemenelemen dari $A$ adalah anggota dari $A$.

Untuk teorema 2.1 (b), kita hanya perlu menunjukkan bahwa "Jika $x \in \varnothing$, maka $x \in A$ " selalu benar dan bagian hipotesis yaitu $x \in \varnothing$ selalu bernilai salah karena $\varnothing$ tidak memiliki anggota. Maka implikasi itu akan selalu bernilai benar tanpa tergantung kepada himpunan A.

Sedangkan untuk teorema 2.1 (c) ditunjukkan dari definisi bahwa jika setiap elemen dari himpunan $A$ adalah elemen dari himpunan $B$, dan setiap elemen dari himpunan $B$ adalah elemen dari himpunan $\mathrm{C}$, maka jelas setiap elemen dari A juga elemen dari C.

\section{F. HIMPUNAN SAMA}

Definisi 2.5. Himpunan A dikatakan sama dengan himpunan $B$ jika dan hanya jika keduanya memiliki elemen yang sama.

Dengan kata lain, A sama dengan B jika A adalah himpunan bagian dari $B$ dan $B$ adalah himpunan bagian dari A. Jika tidak demikian, maka kita katakan A tidak sama dengan $B$.

Notasi : $\mathrm{A}=\mathrm{B} \leftrightarrow \mathrm{A} \subseteq \mathrm{B}$ dan $\mathrm{B} \subseteq \mathrm{A}$

Contoh 2.8

$\mathrm{A}=\{\mathrm{c}, \mathrm{d}, \mathrm{e}\} \quad \mathrm{B}=\{\mathrm{c}, \mathrm{d}, \mathrm{e}\} \quad$ Maka $\mathrm{A}=\mathrm{B}$

Penjelasan :

Himpunan sama memiliki dua buah himpunan yang anggotanya sama misalkan anggota himpunan $A\{c, d, e\}$ maka himpunan $B$ pun akan memiliki anggota yaitu $\{c, d, e\}$. 


\section{G. HIMPUNAN EKIVALEN}

Definisi 2.6. Himpunan A dikatakan ekivalen dengan himpunan B jika dan hanya jika kardinal dari kedua himpunan tersebut sama.

Notasi: $\mathrm{A} \sim B \leftrightarrow|\mathrm{A}|=|\mathrm{B}|$

Contoh 2.9

$A=\{w, x, y, z\} \rightarrow n(A)=4$

$\mathrm{B}=\{\mathrm{r}, \mathrm{s}, \mathrm{t}, \mathrm{u}\} \rightarrow \mathrm{n}(\mathrm{B})=4$

Maka $n(A)=n(B) \rightarrow A \sim B$

Penjelasan :

Himpunan ekivalen mempunyai bilangan kardinal dari himpunan tersebut, bila himpunan A beranggotakan 4 karakter maka himpunan B pun beranggotakan 4.

H. HIMPUNAN SALING LEPAS

Definisi 2.7. Dua himpunan A dan B dikatakan saling lepas jika kedua himpunan tersebut tidak mempunyai anggota yang sama.

Dapat dikatakan himpunan saling lepas adalah suatu himpunan yang anggota-anggotanya berbeda.

Notasi: A // B

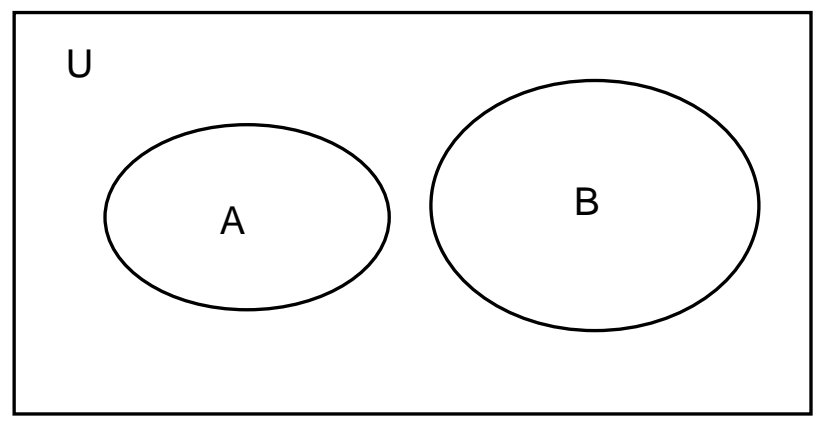

Gambar 2.3 Diagram Venn untuk A // B

Contoh 2.10 
$A=\{a, b, c, d\}$ dan $B=\{p, q, r\}$

Maka himpunan A dan himpunan B saling lepas atau dapat ditulis A // B.

I. HIMPUNAN KUASA

Definisi 2.8. Himpunan kuasa (power set) dari himpunan $A$ adalah suatu himpunan yang elemennya merupakan semua himpunan bagian dari $A$, termasuk himpunan kosong dan himpunan A sendiri.

Notasi: $P(A)$ atau $2^{A}$

Contoh 2.11

Jika $A=\{1,2\}$, maka $P(A)=\{\varnothing,\{1\},\{2\},\{1,2\}\}$

\section{J. OPERASI PADA HIMPUNAN}

Operasi pada himpunan dapat dilakukan pada dua buah himpunan atau lebih.

\section{GABUNGAN}

Definisi 2.9. Himpunan A dan B dikatakan gabungan (Union) jika himpunan yang setiap anggotanya merupakan anggota himpunan A atau himpunan B.

Notasi : $A \cup B=\{x \mid x \in A$ atau $x \in B\}$

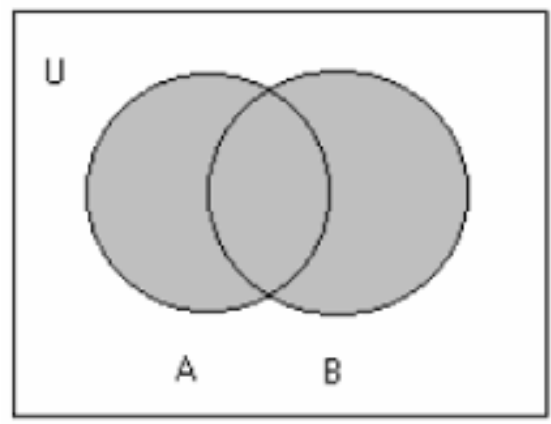

Gambar 2.4 Diagram Venn untuk $A \cup B$ 


\section{Contoh 2.12}

Perhatikan contoh di bawahini!
a. Jika $A=\{1,2,5,7\}$ dan $B=\{0,3,4,6,8\}$, maka:
$A \cup B=\{0,1,2,3,4,5,6,7,8\}$
b. $A \cup \varnothing=A$

\section{IRISAN}

Definisi 2.10. Irisan (intersection) dari himpunan A dan $B$ adalah himpunan yang setiap anggotanya merupakan anggota dari himpunan A dan anggota himpunan $B$.

Notasi : $A \cap B=\{x \mid x \in A$ dan $x \in B\}$

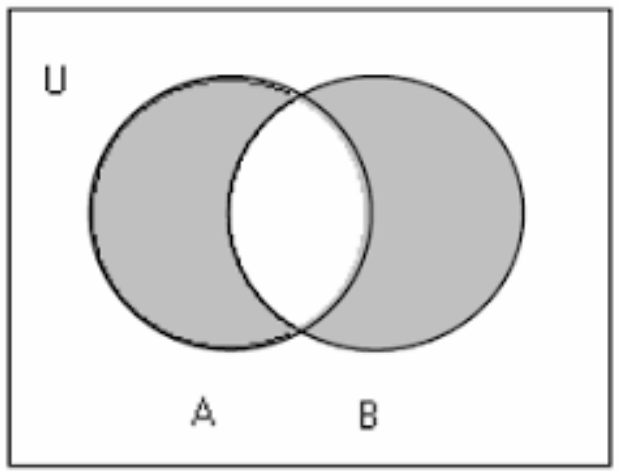

\section{Gambar 2.5 Diagram Venn untuk $A \cap B$}

\section{Contoh 2.13}

Perhatikan contoh di bawah ini!

a. Jika $A=\{$ apel, jeruk, mangga $\}$ dan $B=\{$ apel, semangka $\}$, maka:
$A \cap B=\{$ apel $\}$ 
b. Jika $C=\{$ mobil, kereta, $\operatorname{truk}\}$ dan $B=\{$ pesawat, kapal $\}$, maka $A \cap B=\varnothing$. Atau bisa juga ditulis $A / / B$

\section{KOMPLEMEN}

Definisi 2.11. Komplemen himpunan A terhadap himpunan semesta $U$ adalah himpunan yang anggotanya merupakan anggota $S$ yang bukan anggota $A$.

Notasi : $A^{c}=\{x \mid x \in S$ dan $x \in A\}$

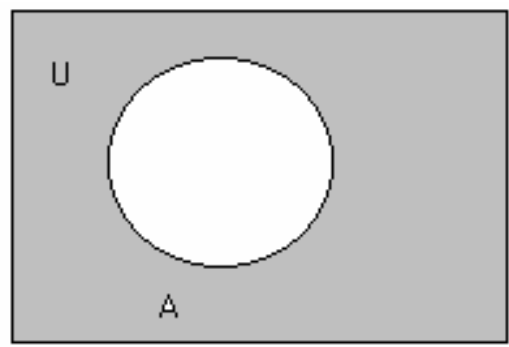

Gambar 2.6 Diagram Venn untuk $A^{c}$

\section{Contoh 2.14}

Misalkan $U=\{1,2,3, \ldots, 9\}$

a. Jika $A=\{2,4,6,8\}$, maka $A^{c}=\{1,3,5,7,9\}$

b. Jika $C=\{x \mid x<6\}$, maka $A^{c}=\{6,7,8,9\}$

\section{SELISIH}

Definisi 2.12. Selisih himpunan A dan B adalah komplemen himpunan $B$ terhadap himpunan $A$.

Notasi : $A-B=\{x \mid x \in A$ dan $x \in B\}$ 


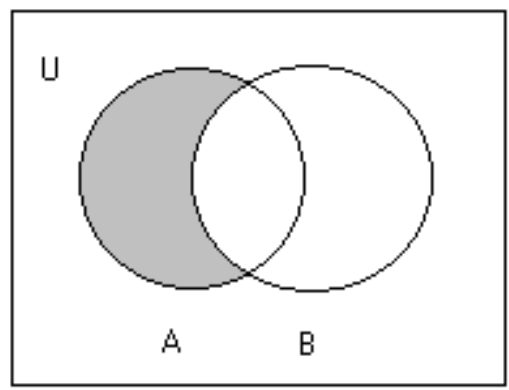

Gambar 2.7 Diagram Venn untuk A - B

\section{Contoh 2.15}

Perhatikan contoh di bawah ini!
a. Jika $A=\{a, b, c, d, e\}$ dan $B=\{b, c, d\}$, maka

$$
A-B=\{a, e\}
$$
b. $\{1,2,3\}-\{1,3,5\}=\{2\}$, tetapi $\{1,3,5\}-\{1,2,3\}=\{5\}$

\section{BEDA SETANGKUP}

Definisi 2.13. Himpunan A dan B dikatakan beda setangkup jika suatu himpunan yang elemennya ada pada himpunan $A$ atau $B$, tetapi tidak pada keduanya.

Notasi: $A \oplus B=(A \cup B)-(A \cap B)=(A-B) \cup(B-A)$

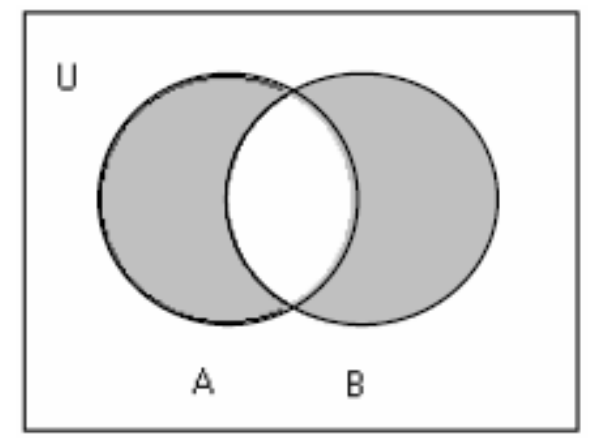

Gambar 2.8 Diagram Venn untuk $A \oplus B$

\section{Contoh 2.16}


Perhatikan contoh di bawah ini!

a. Jika $A=\{a, i, u, e, o\}$ dan $B=\{k, o, m, p, u, t, e, r\}$, maka $A \oplus B=\{a, i, k, m, p, t, r\}$

b. Misalkan :

$\mathrm{U}=$ himpunan mahasiswa

$\mathrm{P}=$ himpunan mahasiswa yang nilai UTS di atas 80

$\mathrm{Q}=$ himpunan mahasiswa yang nilai UAS di atas 80

Seorang mahasiswa mendapat nilai A jika nilai UTS dan nilai UAS keduanya di atas 80 , mendapat nilai $\mathrm{B}+$ jika salah satu ujian di atas 80 , dan mendapat nilai B- jika kedua ujian mendapat nilai di bawah 80. Sehingga, notasi himpunannya adalah sebagai berikut:
a. "Semua mahasiswa yang mendapat nilai A" adalah $P \cap Q$
b. "Semua mahasiswa yang mendapat nilai $B+$ " adalah $\mathrm{A} \oplus \mathrm{B}$
c. "Semua mahasiswa yang mendapat nilai B-" adalah $U-(A \cup B)$

\section{HASIL KALI KARTESIUS ( CARTESION PRODUCT )}

Definisi 2.14. Hasil kali kartesius dari himpunan A dan $B$ adalah himpunan pasangan berurutan $(a, b)$ dengan a anggota himpunan $A$ dan $b$ anggota himpunan $B$.

Notasi : $A \times B=\{(a, b) \mid a \in A$ dan $b \in B\}$ Contoh 2.17

Perhatikan contoh di bawah ini!

a. Misalkan $A=\{$ apel, jeruk, mangga $\}$ dan $D=\{$ manis, masam\}, maka perkalian kartesian A dan B adalah $A \times B=\{($ apel, manis), (apel, masam), (jeruk , manis), (jeruk, masam), (mangga, manis), (mangga, masam)\}

b. Misalkan: 
$C=$ himpunan makanan $=\{b=$ bakso, $s=$ soto, $m=$ mie ayam, $r=$ rujak $\}$

$D=$ himpunan minuman $=\{s=$ sirup, $j=j u s, k=k o p i\}$

Berapa banyak kombinasi dari makanan minuman yang mungkin dapat disusun?

Penyelesaian:

$|A \times B|=|A| \cdot|B|=4.3=12$ kombinasi makanan dan minuman, yaitu $\{(b, s),(b, j),(b, k),(s, s),(s, j),(s, k)$, $(m, s),(m, j),(m, k),(r, s),(r, j),(r, k)\}$.

\section{K. HUKUM ALJABAR HIMPUNAN}

Tabel 2.1 Tabel Hukum-hukum Aljabar Himpunan

\begin{tabular}{|c|c|}
\hline $\begin{array}{l}\text { 1. Hukum identitas: } \\
\text { i. } \quad A \cup \emptyset=\mathrm{A} \\
\text { ii. } \quad A \cap U=A\end{array}$ & $\begin{array}{l}\text { 2. Hukum null/dominasi: } \\
\begin{array}{l}\text { i. } \quad A \cap \varnothing=\varnothing \\
\text { ii. } \quad A \cup U=\mathrm{U}\end{array}\end{array}$ \\
\hline $\begin{array}{l}\text { 3. Hukum komplemen: } \\
\text { i. } \quad A \cup A^{c}=\mathrm{U} \\
\text { ii. } \quad A \cap A^{c}=\varnothing\end{array}$ & $\begin{array}{l}\text { 4. Hukum idempoten: } \\
\begin{array}{l}\text { i. } \quad A \cup A=A \\
\text { ii. } \quad A \cap A=A\end{array}\end{array}$ \\
\hline $\begin{array}{r}\text { 5. Hukum involusi: } \\
\qquad\left(A^{c}\right)=A\end{array}$ & $\begin{array}{l}\text { 6. Hukum penyerapan } \\
\text { (absorpsi): } \\
\begin{aligned} \text { i. } \quad & A \cup(A \cap B)=A \\
\text { ii. } \quad & A \cap(A \cup B)=A\end{aligned}\end{array}$ \\
\hline $\begin{array}{l}\text { 7. Hukum komutatif: } \\
\text { i. } \quad A \cup B=B \cup A \\
\text { ii. } A \cap B=B \cap A\end{array}$ & $\begin{array}{l}\text { 8. Hukum asosiatif: } \\
\text { i. } A(B C)=(A B) C \\
\text { ii. } A \cap(B \cap C)=(A \cap B) \cap C\end{array}$ \\
\hline $\begin{array}{l}\text { 9. Hukum distributif: } \\
\text { i. } A \cup(B \cap C)=(A \cup B) \cap(A \cup C) \\
\text { ii. } A \cap(B \cup C)=(A \cap B) \cup(A \cap C)\end{array}$ & $\begin{array}{l}\text { 10. Hukum De Morgan: } \\
\text { i. } \overline{A \cap B}=\bar{A} \cup \bar{B} \\
\text { ii. } \overline{A \cup B}=\bar{A} \cap \bar{B}\end{array}$ \\
\hline
\end{tabular}


11. Hukum $0 / 1$

$$
\begin{aligned}
\text { i. } & \bar{\emptyset}=\mathrm{U} \\
\text { ii. } & \bar{U}=\varnothing
\end{aligned}
$$

Dari tabel di atas terlihat bahwa hukum- hukum yang berlaku pada himpunan merupakan analogi dari hukumhukum logika, dengan operator $U$ sebagai dan, sedangkan operator $\cap$ sebagai atau.

\section{PRINSIP INKLUSI DAN EKSKLUSI}

Penggabunggan dua buah himpunan yaitu himpunan A dan himpunan $B$ akan didapatkan himpunan baru yang elemen-elemennya dari himpunan A dan himpunan B. Banyaknya penggabungan elemen dari himpunan $A$ dan himpunan $B$ dilambangkan $|A \cap B|$. Setiap elemen yang sama dihitung dua kali yaitu pada $|A|$ dan pada $|B|$, walaupun seharusnya hanya satu elemen di dalam $|A \cup B|$. Sehingga didapat jumlah elemen hasil penggabungan adalah jumlah elemen di setiap himpunan dikurangi dengan jumlah elemen di dalam irisannya.

Prinsip ini dikenal dengan nama prinsip inklusi -eksklusi.

$$
|A \cup B|=|A|+B|-| A \cap B \mid
$$

Adapun prinsip inklusi-eksklusi penjabarannya sebagai berikut menurut lemma dan teorema berikut:

Lemma 2.1. Misalkan A dan B adalah himpunan berhingga yang saling lepas (disjoint), maka

$$
|A \cup B|=|A|+|B|
$$

Teorema 2.2. Misalkan $A$ dan $B$ adalah himpunan berhingga maka $|A \cup B|$ berhingga sehingga

$$
|A \cup B|=|A|+|B|-|A \cap B|
$$

Dengan cara yang sama, kita dapat menghitung jumlah elemen hasil operasi beda setangkup:

\section{Contoh 2. 18}

$$
|A \oplus B|=|A|+|B|-2|A \cap B|
$$

Berapa banyaknya bilangan bulat antara 1 dan 500 yang habis dibagi 2 atau 5

Penyelesaian :

Misalkan : $\mathrm{A}=$ himpunan bilangan bulat yang habis dibagi 


$$
5 \quad B=\text { himpunan bilangan bulat yang habis dibagi }
$$

$A \cap B=$ himpunan bilangan bulat yang habis dibagi

2 dan 5 (himpunan bilangan bulat yang habis dibagi oleh KPK dari 2 dan 5 adalah 10 ).

Yang ditanyakan $|\mathrm{A} \cup \mathrm{B}|$

Langkah pertama:

$|\mathrm{A}|=[500 / 2]=250 \quad|\mathrm{~B}|=[500 / 5]=$ 100

$|A \cap B|=[500 / 10]=50$
Untuk mendapatkan $|A \cup B|=|A|+B|-| A \cap B \mid$

$$
=250+100-50=300
$$

Jadi bilangan yang habis dibagi 2 atau 5 ada 300 .

Prinsip inklusi- eksklusi dapat digunakan untuk operasi lebih dari dua buah himpunan. untuk tiga buah himpunan $A$, B, dan $C$ berlaku teorema berikut:

Teorema 2.3 Misalkan A, B , dan C adalah himpunan yang berhingga maka $|A \cup B \cup C|$ berhingga dan

$$
\begin{aligned}
& |A \cup B \cup C|=|A|+|B|+|C|-|A \cap B|-|A \cap C|-|B \cap C|+ \\
& |A \cap B \cap C|
\end{aligned}
$$

Sedangkan untuk empat buah himpunan maka

$|A \cup B \cup C \cup D|=|A|+|B|+|C|+|D|-|A \cap B|-|A \cap C|$ $-|A \cap D|-|B \cap C|-|B \cap D|-|C \cap D|+|A \cap B \cap C|+\mid A$ $\cap B \cap D|+| A \cap C \cap D|+| B \cap C \cap D|-| A \cap B \cap C \cap D \mid$

\section{Contoh 2.19}

Dari 100 jumlah mahasiswa Informatika di kelas, sebanyak 45 orang mahasiswa menyukai sepakbola, 24 orang mahasiswa menyukai basket, dan 16 orang mahasiswa menyukai volly. Sebanyak 42 orang mahasiswa menyukai sepakbola dan basket, 22 orang mahasiswa menyukai sepakbola dan volly, dan 11 orang mahasiswa menyukai basket dan volly. Berapa banyak mahasiswa yang menyukai ketiga jenis olahraga tersebut?

Penyelesaian : 
Misalkan :

$A=$ himpunan mahasiswa yang menyukai sepakbola

$B=$ himpunan mahasiswa yang menyukai basket

$C=$ himpunan mahasiswa yang menyukai volly

Maka,
$|A|=35$
$|B|=24$
$|C|=16$
$|A \cap B|=42$
$|A \cap C|=22$
$|B \cap C|=11$

dan $|A \cup B \cup C|=100$

Dengan menggunakan prinsip inklusi -eksklusi diperoleh:

$|A \cup B \cup C|=|A|+|B|+|C|-|A \cap B|-|A \cap C|-$

$|B \cap C|+|A \cap B \cap C|$

$100=45+24+16-42-22-11+|A \cap B \cap C|$

Sehingga $|A \cap B \cap C|=10$

Jadi ada 10 orang mahasiswa yang menyukai ketiga jenis olah raga yaitu sepakbola, basket dan volly.

\section{PEMBUKTIAN PROPORSI HIMPUNAN}

Ada beberapa metode pembuktikan kebenaran dari suatu proposisi himpunan yang dapat menemukan kesimpulan yang sama. Berikut metode-metode dalam pembuktian kebenaran suatu proposisi himpunan:

\section{a. Diagram venn}

Untuk membuktikan suatu proposisi himpunan dengan mengunakan diagram venn maka yang harus dilakukan adalah membuat dua diagram venn yaitu ruas kiri dan ruas kanan. Kesamaan himpunan tersebut benar jika kedua diagram venn tersebut sama.

Kelebihan metode ini yaitu pembuktian dapat dilakukan dengan cepat sedangkan kekurangannya adalah hanya dapat digunakan pada himpunan yang digambarkan sedikit jumlahnya. Metode ini jarang digunakan oleh matematikawan karena pembuktian dengan metode cenderung memberikan ilustrasi daripada menggunakan fakta. 


\section{Contoh 2.21}

Misalkan $\mathrm{R}, \mathrm{S}$, dan $\mathrm{T}$ adalah himpunan. Buktikan $\mathrm{R} \cap$ $(S \cup T)=(R \cap S) \cup(R \cap T)$ dengan diagram Venn!

\section{Penyelesaian:}

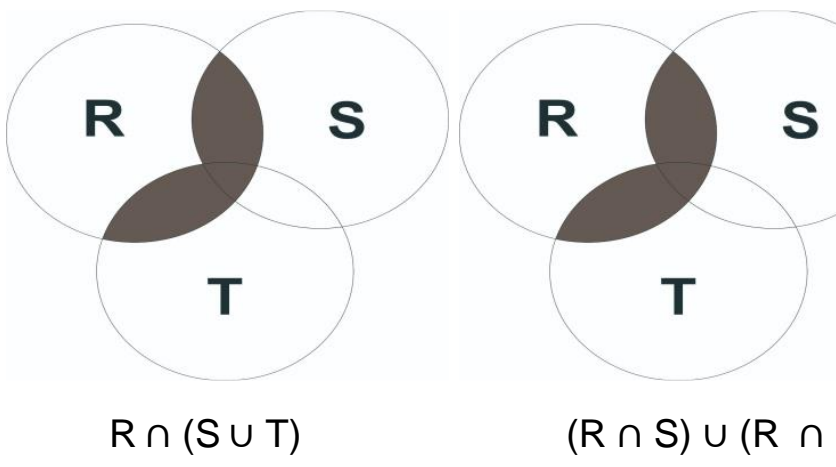

Gambar 2.9 Diagram Ventr untuk permbuktian $R \cap$ (S V

$$
T)=(R \cap S) \cup(R \cap T)
$$

Berdasarkan diagram venn di atas maka

Terbukti

$$
R \cap(S \cup T)=(R \cap S) \cup(R \cap T)
$$

\section{b. Tabel keanggotaan}

Tabel kegunaan digunakan untuk membuktikan kesamaan himpunan. Kita menggunakan angka 1 untuk menyatakan bahwa suatu elemen adalah anggota himpunan, dan 0 untuk menyatakan bukan himpunan. (nilai ini dapat diartikan dengan true dan false).

\section{Contoh 2.20}

Misalkan R, S, dan $\mathrm{T}$ adalah himpunan. Buktikan bahwa

$$
R \cap(S \cup T)=(R \cap S) \cup(R \cap T)
$$

dengan menggunkan tabel keanggotaan. Perhatikan tabel 2.2 
Tabel 2.2. Pembuktian $R \cap(S \cup T)=(R \cap S) \cup(R \cap$

$\mathrm{T})$

\begin{tabular}{|c|c|c|c|c|c|c|c|}
\hline $\mathrm{R}$ & $\mathrm{S}$ & $\mathrm{T}$ & $R \cup S$ & $R \cap(S U$ & $R \cap$ & $R \cap T$ & $(R \cap S) \cup(R \cap$ \\
& & & & $T)$ & $S$ & & $T)$ \\
\hline 0 & 0 & 0 & 0 & $\mathbf{0}$ & 0 & 0 & $\mathbf{0}$ \\
\hline 0 & 0 & 1 & 1 & $\mathbf{0}$ & 0 & 0 & $\mathbf{0}$ \\
\hline 0 & 1 & 0 & 1 & $\mathbf{0}$ & 0 & 0 & $\mathbf{0}$ \\
\hline 0 & 1 & 1 & 1 & $\mathbf{0}$ & 0 & 0 & $\mathbf{0}$ \\
\hline 1 & 0 & 0 & 0 & $\mathbf{0}$ & 0 & 0 & $\mathbf{0}$ \\
\hline 1 & 0 & 1 & 1 & $\mathbf{1}$ & 0 & 1 & $\mathbf{1}$ \\
\hline 1 & 1 & 0 & 1 & $\mathbf{1}$ & 1 & 0 & $\mathbf{1}$ \\
\hline 1 & 1 & 1 & 1 & $\mathbf{1}$ & 1 & 1 & $\mathbf{1}$ \\
\hline
\end{tabular}

Dari tabel tersebut terlihat bahwa kolom $R \cap(S U T)$ dan kolom $(R \cap S) \cup(R \cap T)$ sama maka kesamaan tersebut benar

c. Aljabar himpunan

Pembuktian dengan menggunakan hukum-hukum aljabar himpunan.

Contoh 2.21

Misalkan S dan T himpunan . buktikan bahwa

Penyelesaian :

$$
S U(T-S)=S U T
$$

$S U(T-S)=S U\left(T \cap S^{c}\right) \quad$ definisi operasi selisih

$$
\begin{array}{lr}
=(S \cup T) \cap\left(S \cup S^{c}\right) & \text { hukum distributif } \\
=(S \cup T) \cap U & \text { hukum komplemen } \\
=S U T & \text { hukum identitas }
\end{array}
$$

Terbukti

d. Definisi

Metode definisi ini digunakan untuk membuktikan proposisi yang berbentuk implikasi. Biasanya di dalam implikasi tersebut ada notasi himpunan bagian $\subseteq$. 
Contoh 2.22

Buktikan bahwa $\mathrm{X} \subseteq \mathrm{Y}$ dengan mengunakan definisi! Penyelesaian:

Cara untuk membuktikan bahwa $\mathrm{X} \subseteq \mathrm{Y}$ adalah :

- Ambil sebarang $x \subseteq X$

- Tunjukkan bahwa $\mathrm{x} \subseteq \mathrm{Y}$ dengan langkah-langkah yang tepat

Karena $\mathrm{x}$ sembarang anggota dalam $X$, maka setiap anggota $X$ merupakan anggota $Y$ atau $X \subseteq Y$. Pembuktian yang melibatkan kesamaan himpunan $(X=Y)$ haruslah melalui 2 arah sesuai dengan definisinya, yaitu $X \subseteq Y$ dan $Y \subseteq X$.

\section{KESIMPULAN}

1. Himpunan adalah kumpulan objek-objek yang berbeda.

2. Objek yang terdapat dalam himpunan disebut elemen, unsur atau anggota.

3. Penyajian himpunan ada empat cara yaitu enumerasi, simbolsimbol baku, notasi pembentuk himpunan dan diagram Venn.

4. Dua himpunan A dan B dikatakan saling lepas jika kedua himpunan tersebut tidak mempunyai anggota yang sama.

5. Himpunan kuasa (power set) dari himpunan $A$ adalah suatu himpunan yang elemennya merupakan semua himpunan bagian dari $A$, termasuk himpunan kosong dan himpunan $A$ sendiri.

6. Gabungan (union) dari himpunan A dan B adalah himpunan yang setiap anggotanya merupakan anggota himpunan $A$ atau himpunan B. Notasi : $A \cup B=\{x \mid x \in A$ atau $x \in B\}$ 
7. Irisan (intersection) dari himpunan A dan B adalah himpunan yang setiap anggotanya merupakan anggota dari himpunan $A$ dan anggota himpunan $B$. Notasi : $A \cap B=\{x \mid x \in A$ dan $x \in B\}$

8. Komplemen himpunan $A$ terhadap himpunan semesta $U$ adalah himpunan yang anggotanya merupakan anggota $S$ yang bukan anggota $A$. Notasi : $A^{c}=\{x \mid x \in S$ dan $x \in A\}$

9. Selisih himpunan $A$ dan $B$ adalah komplemen himpunan $B$ terhadap himpunan $A$. Notasi : $A-B=\{x \mid x \in A$ dan $x \in B\}$

10. Beda setangkup dari himpunan $A$ dan $B$ adalah suatu himpunan yang elemennya ada pada himpunan $A$ atau $B$, tetapi tidak pada keduanya. Notasi: $A \oplus B=(A \cup B)-(A \cap B)=(A-B) \cup(B-A)$

11. Hasil kali kartesius dari himpunan $A$ dan $B$ yaitu himpunan pasangan berurutan $(a, b)$ dengan $a$ anggota himpunan $A$ dan $b$ anggota himpunan $B$.

Notasi : $A \times B=\{(a, b) \mid a \in A$ dan $b \in B\}$

12. Prinsip inklusi eksklusi $|A \cup B|=|A|+B|-| A \cap B \mid$

\section{LATIHAN SOAL}

1. Misalkan A adalah himpunan. Periksalah apakah setiap pernyataan di bawah ini benar atau salah dan jika salah bagaimana seharusnya:
a. $A \cap P(A)=P(A)$
b. $\{A\} \cup P(A)=P(A)$
c. $\quad A-P(A)=(A)$
d. $\{A\} \in P(A)$

2. Mlsalkan $A=\{1,2,3\}$ dan $B=\{1,2,3,4,5\}$. Tentukan semua kemungkinan himpunan $C$ sedemikian hingga $A \subseteq C$ dan $C \subseteq B$, yaitu $A$ adalah himpunan bagian sebenarnya (proper subset) dari $\mathrm{C}$ dan $\mathrm{C}$ adalah himpunan bagian sebenarnya (proper subset) dari B! 
3. Diberikan $A=\{1,2\}, B=\{a, b, c\}$ dan $C=\{3,4\}$. Tentukan :

$$
|A \times B \times C| \text { dan } A \times B \times C \text { ! }
$$

4. Misalkan $P, Q$, dan $R$ adalah suatu himpunan. Buktikan secara aljabar himpunan bahwa $P-(Q \cup R)=(P-Q) \cap(P-R)$ !

5. Di antara bilangan bulat antara $101-500$ (termasuk 101 dan 500 ), berapa banya bilangan yang tidak habis dibagi oleh 4 atau 5 namum tidak keduanya? 


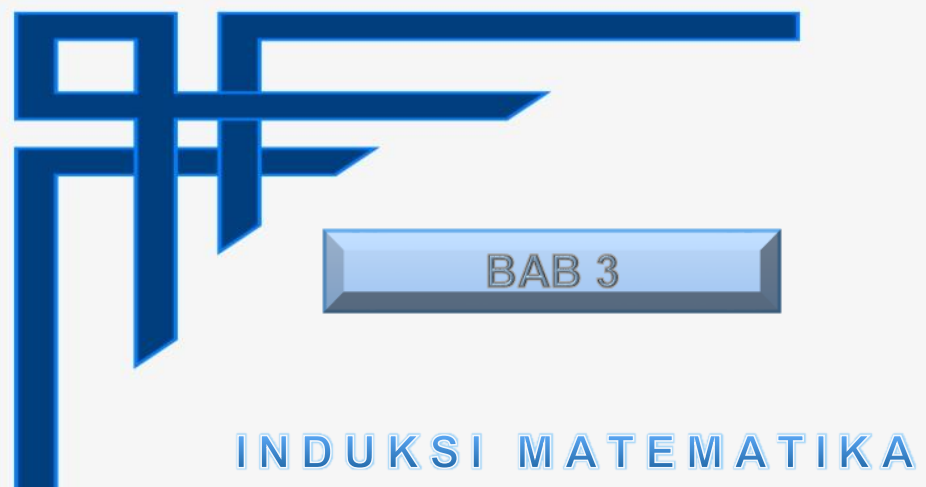

CAPAIAN PEMBELAJARAN:

1. Mahasiswa mampu memahami konsep induksi matematika

2. Mahasiswa mampu membuktikan suatu permasalahan dengan menggunakan induksi matematika 
Sebuah proposisi atau pernyataan dalam matematika tidak hanya sekedar ditulis pasti ada alasannya. Kita harus tahu dan mengerti apa yang menjadi penyebab proposisi tersebut benar yaitu dengan cara pembuktian. Bab 1 kita sudah membahas metode pembuktian untuk argumen dan dalam Bab 2 kita telah membahas mengenai pembuktian proposisi yang menyangkut himpunan. Dalam Bab 3 ini kita hanya akan membahas pembuktian pada bilangan bulat yang disebut induksi matematika.

\section{A. Pernyataan Perihal Bilangan Bulat}

Induksi matematika adalah suatu metode pembuktian dalam matematika yang bentuknya baku dengan elemennya adalah bilangan bulat.

Dengan induksi matematika langkah-langkah pembuktian dapat dikurangi dengan mengganggap semua bilangan bulat yang ada dalam suatu himpunan kebenaran .

\section{Contoh 3.1}

Jumlah bilangan bulat positif dari 1 sampai $\mathrm{n}$ adalah $n(n+1) / 2$

Bukti :

Andailkan $\mathrm{n}=8 \rightarrow \mathrm{p}(8)$ adalah "Jumlah bilangan bulat positif dari 1 sampai 8 adalah $8(8+1) / 2$ "

Maka :

$$
1+2+3+4+5+6+7+8=36 \rightarrow 8(9) / 2=72 / 2=36
$$

Sehingga proposisi (pernyataan) tersebut benar

\section{Contoh 3.2}

Jumlah $n$ buah bilangan ganjil positif pertama adalah $n^{2}$. Bukti :

Andaikan $\mathrm{n}=8$ buah $(\mathrm{n}=1,2,3,4,5,6,7,8)$ sehingga :

$\mathrm{n}=1 \rightarrow 1=1$

$\rightarrow(1)^{2}=1$

$\mathrm{n}=2 \rightarrow 1+3=4$

$\rightarrow(2)^{2}=4$

$\mathrm{n}=3 \rightarrow 1+3+5=9$

$\rightarrow(3)^{2}=9$

$\mathrm{n}=4 \rightarrow 1+3+5+7=16$

$(4)^{2}=16$ 


$$
\begin{aligned}
& \mathrm{n}=5 \rightarrow 1+3+5+7+9=25 \rightarrow(5)^{2}=25 \\
& \mathrm{n}=6 \rightarrow 1+3+5+7+9+11=36 \rightarrow(6)^{2}=36 \\
& \mathrm{n}=7 \rightarrow 1+3+5+7+9+11+13=49 \rightarrow(7)^{2}=49 \\
& \mathrm{n}=8 \rightarrow 1+3+5+7+9+11+13+15=64 \rightarrow(8)^{2}=64
\end{aligned}
$$

Sehingga proposisi (pernyataan) tersebut benar

\section{B. Prinsip induksi sederhana}

Prinsip induksi sederhana berbunyi:

Andaikan $\mathrm{p}(\mathrm{n})$ adalah proposisi bilangan bulat positif dan untuk membuktikan bahwa $p(n)$ adalah benar untuk semua bilangan bulat positif $n$. Maka langkah-langkahnya adalah tunjukkan bahwa;

1. $p(n)$ benar

Langkah ini dinamakan Basis induksi

Digunakan untuk memperlihatkan bahwa pernyataan benar bila $n$ diganti dengan 1, yang merupakan bilangan bulat positif terkecil

Buat implikasi untuk fungsi berikutnya benar untuk setiap bilangan bulat positif

2. Jika $p(n)$ benar, maka $p(n+1)$ juga benar untuk setiap $n \geq 1$. Sehingga $p(n)$ benar untuk semua bilangan bulat positif $n$.

Sedangkan langkah kedua ini dinamakan Langkah induksi

suatu pernyataan berasumsi bahwa $p(n)$ benar.

Asumsi itu disebut hipotesis induksi.

Bila kedua langkah tersebut benar maka pembuktian bahwa $\mathrm{p}(\mathrm{n})$ benar untuk semua bilangan positif $n$.

\section{Contoh 3.4}

Buktikan bahwa untuk $n \geq 1,1+2+3+\ldots+n=n(n+1) / 2$ dengan induksi matematika

Penyelesaian :

i. Basis induksi

$$
\mathrm{p}(2) \text { benar } \rightarrow \mathrm{n}=2 \text { didapat dari : }
$$

$$
1+2=2(2+1) / 2
$$




$$
\begin{aligned}
& =2(3) / 2 \\
& =6 / 2 \\
& =3
\end{aligned}
$$

ii. Langkah induksi (ii)

Misalkan $\mathrm{p}(\mathrm{n})$ benar $\rightarrow$ asumsi bahwa :

$$
1+2+3+\ldots+n=n(n+1) / 2
$$

Adalah benar (hipotesis induksi). Perlihatkan bahwa $p(n+1)$ juga benar yaitu :

$$
\begin{aligned}
1+2+3+\ldots+n+(n+1) & =(n+1)[(n+1)+1] / 2 \\
1+2+3+\ldots+n+(n+1)= & (1+2+3+\ldots+n)+(n+1) \\
= & (n(n+1) / 2)+(n+1) \\
& =\left(\left(n^{2}+n\right) / 2\right)+(n+1) \\
& =\left(\left(n^{2}+n\right) / 2\right)+((2 n+2) / 2) \\
& =\left(n^{2}+3 n+2\right) / 2 \\
& =(n+1)(n+2) / 2 \\
& =(n+1)[(n+1)+1] / 2
\end{aligned}
$$

Langkah (i) dan (ii) terbukti, maka untuk semua bilangan bulat positif $n$, terbukti bahwa untuk semua $n \geq 1$, $1+2+3+\ldots+n=n(n+1) / 2$

\section{Contoh 3.5}

Buktikan bahwa jumlah $\mathrm{n}$ buah bilangan ganjil positif pertama adalah $n^{2}$ dengan menggunakan induksi matematika.

Penyelesaian :

i. Basis induksi

$\mathrm{p}(1)$ benar $\rightarrow$ jumlah 1 buah bilangan ganjil positif pertama adalah $1^{2}=1$

ii. Langkah induksi 
Misalkan $p(n)$ benar $\rightarrow$ asumsi bahwa :

$$
1+3+5+\ldots+(2 n-1)=n^{2}
$$

Adalah benar (hipotesis induksi)

Perlihatkan bahwa $p(n+1)$ juga benar, yaitu :

$$
1+3+5+\ldots+(2 n-1)+(2 n+1)=(n+1)^{2}
$$

Hal ini dapat ditunjukkan sebagai berikut :

$$
\begin{aligned}
1+3+5+ & \ldots+(2 n-1)+(2 n+1)=[1+3+5 \\
& =n^{2}+(2 n+1) \\
& =n^{2}+2 n+1 \\
& =(n+1)^{2}
\end{aligned}
$$

Karena kedua langkah dapat dibuktikan benar, maka untuk jumlah $n$ buah bilangan ganjil positif pertama adalah $n^{2}$

Bentuk Umum Prinsip Induksi Sederhana (generalized) Andaikan $p(n)$ adalah proposisi tentang bilangan bulat $n \geq n_{0}$. Maka pembuktiannya ditunjukkan bahwa :

1. $p\left(n_{0}\right)$ benar

2. Jika $p(n)$ benar, maka $p(n+1)$ juga benar untuk setiap $n \geq n_{0}$

sehingga $p(n)$ benar untuk semua bilangan bulat $n \geq n_{0}$.

\section{Contoh 3.6}

Untuk semua bilangan bulat tidak negatif $n$, buktikan dengan induksi matematika bahwa $2^{0}+2^{1}+2^{2}+\ldots+2^{n}=2^{n+1}$ $-1$

Penyelesaian:

Misalkan $p(n)$ adalah proposisi bahwa untuk semua bilangan bulat tidak negatif $n, 2^{0}+2^{1}+2^{2}+\ldots+2^{n}=2^{n+1}-1$

i. Basis induksi

$p(0)$ benar $\rightarrow$ untuk $n=0$ (bilangan bulat tidak negatif pertama) diperoleh dari :

$$
\begin{aligned}
2^{0} & =2^{0+1}-1 \\
1 & =2^{1}-1 \\
1 & =2-1
\end{aligned}
$$


ii. Langkah induksi

$$
1=1
$$

Andaikan $\mathrm{p}(\mathrm{n})$ benar, yaitu:

$$
2^{0}+2^{1}+2^{2}+\ldots+2^{n}=2^{n+1}-1
$$

diasumsikan benar (hipotesis induksi).

Tunjukkan bahwa $p(n+1)$ juga benar, yaitu :

$2^{0}+2^{1}+2^{2}+\ldots+2^{n}+2^{n+1}=2^{(n+1)+1}-1$

Diperoleh:

$$
\begin{aligned}
2^{0}+2^{1}+2^{2}+\ldots+2^{n}+ & 2^{n+1}=\left(2^{0}+2^{1}+2^{2}+\ldots+2^{n}\right)+2^{(n+1)} \\
& =2^{(n+1)+1}-1+2^{n+1} \quad \text { (dari hipotesis } \\
& \text { induksi) } \\
& =\left(2^{n+1}+2^{n+1}\right)-1 \\
& =\left(2 \cdot 2^{n+1}\right)-1 \\
& =2^{n+2}-1 \\
& =2^{(n+1)+1}-1
\end{aligned}
$$

Karena kedua langkah dapat dibuktikan benar, maka untuk semua bilangan bulat tidak negatif $n$, terbukti bahwa $2^{0}+$ $2^{1}+2^{2}+\ldots+2^{n}=2^{n+1}-1$

\section{Contoh 3.7}

Buktikan dengan induksi matematika bahwa $3^{\text {n }}<n$ ! untuk $\mathrm{n}$ bilangan bulat positif yang lebih besar dari 6

Penyelesaian:

Andaikan $\mathrm{p}(\mathrm{n})$ adalah benar bahwa $3^{\mathrm{n}}<\mathrm{n}$ ! untuk $\mathrm{n}$ bilangan bulat positif yang lebih besar dari 6

i. Basis induksi

$$
\mathrm{p}(7) \text { benar } \rightarrow 3^{7}<7 ! \leftrightarrow 2187<5040
$$

ii. Langkah induksi

Tunjukkan juga bahwa $p(n+1)$ juga benar, yaitu $3^{n+1}<$ $(n+1)$ !

$$
\begin{aligned}
& 3^{n+1}<(n+1) ! \\
& 3 \cdot 3^{n}<(n+1) \cdot n ! \\
& 3^{n} \cdot 3 /(n+1)<n !
\end{aligned}
$$

Menurut hipotesis induksi, $3^{\mathrm{n}}<\mathrm{n}$ !, sedangkan untuk $\mathrm{n}$ $>6$, nilai $3 /(n+1)<1$, sehingga $3 /(n+1)$ akan memperkecil nilai di ruas kiri persamaan. Sehingga, $3^{n}$ . $3 /(n+1)<n$ ! benar 
Karena kedua langkah dapat dibuktikan benar, maka terbukti bahwa $3^{n}<n$ ! untuk $n$ bilangan bulat positif lebih besar dari 6

\section{Contoh 3.8}

Tunjukkan bahwa :

$$
1+2+3+\ldots+n=1 / 2 n(n+1)
$$

untuk setiap $n$ bilangan bulat positif

Penyelesaian :

i. Basis induksi

Untuk $\mathrm{n}=1$ akan diperoleh :

$$
1=1 / 21 .(1+1)->1=1
$$

ii. Langkah induksi

misalkan untuk $n=k$ asumsikan $1+2+3+\ldots+k=1 / 2$ $\mathrm{k}(\mathrm{k}+1)$

Untuk $\mathrm{n}=\mathrm{k}+1$ berlaku $1+2+3+\ldots+(\mathrm{k}+1)=1 / 2(\mathrm{k}+1)$ $(\mathrm{k}+2)$

$1+2+3+\ldots+(\mathrm{k}+1)=(\mathrm{k}+1)(\mathrm{k}+2) / 2$

$1+2+3+\ldots+k+(k+1)=(k+1)(k+2) / 2$

$\mathrm{k}(\mathrm{k}+1) / 2+(\mathrm{k}+1)=(\mathrm{k}+1)(\mathrm{k}+2) / 2$

$(k+1)[k / 2+1] \quad=(k+1)(k+2) / 2$

$(\mathrm{k}+1) 1 / 2(\mathrm{k}+2) \quad=(\mathrm{k}+1)(\mathrm{k}+2) / 2$

$(\mathrm{k}+1)(\mathrm{k}+2) / 2=(\mathrm{k}+1)(\mathrm{k}+2) / 2$

Karena kedua langkah dapat dibuktikan benar, maka terbukti bahwa $1+2+3+\ldots+n=1 / 2 n(n+1)$ untuk setiap bilangan bulat positif $n$

\section{Contoh 3.9}

Buktikan bahwa $1+3+5+\ldots+n=(2 n-1)=n^{2}$, untuk setiap $\mathrm{n}$ bilangan bulat positif.

Penyelesaian:

i. Basis induksi

Untuk $\mathrm{n}=1$ akan diperoleh :

$$
1=1^{2} \rightarrow 1=1
$$

ii. Langkah induksi :

misalkan untuk $n=k$ asumsikan $1+3+5+\ldots+(2 k-$ 
1) $=k^{2}$

$$
\begin{aligned}
& \text { Untuk } \mathrm{n}=\mathrm{k}+1 \text { berlaku: } \\
& 1+3+5+\ldots+(2(k+1)-1)=(k+1)^{2} \\
& 1+3+5+\ldots+(2 k+1)=(k+1)^{2} \\
& 1+3+5+\ldots+((2 \mathrm{k}+1)-2)+(2 \mathrm{k}+1)=(\mathrm{k}+1)^{2} \\
& 1+3+5+\ldots+(2 \mathrm{k}-1)+(2 \mathrm{k}+1)=(\mathrm{k}+1)^{2} \\
& \mathrm{k}^{2}+(2 \mathrm{~K}+1)=(\mathrm{k}+1)^{2} \\
& \mathrm{k}^{2}+2 \mathrm{~K}+1=\mathrm{k}^{2}+2 \mathrm{~K}+
\end{aligned}
$$

1

Karena kedua langkah dapat dibuktikan benar, maka terbukti bahwa $1+3+5+\ldots+n=(2 n-1)=n^{2}$, untuk setiap bilangan bulat positif $n$

\section{Prinsip Induksi Kuat}

Prinsip induksi yang lebih kuat kadang-kadang diperlukan untuk membuktikan pernyataan mengenai bilangan bulat. Prinsip induksi kuat adalah sebagai berikut:

Misalkan $p(n)$ adalah pernyataan tentang bilangan bulat dan untuk membuktikan bahwa $p(n)$ benar untuk semua bilangan bulat $n \geq n_{0}$, tunjukkan bahwa:

1. $p\left(n_{0}\right)$ benar, dan

2. Jika $p\left(n_{0}\right), p\left(n_{0}+1\right), \ldots, p(n)$ benar, maka $p(n+1)$ juga benar untuk setiap bilangan bulat $n \geq n_{0}$, sehingga $p(n)$ benar untuk semua bilangan bulat $n \geq n_{0}$.

Prinsip induksi kuat ini hampir sama dengan induksi sederhana, kecuali pada langkah 2 yaitu kita mengambil hipotesis induksi yang lebih kuat bahwa semua pernyataan $p(1), p(2), \ldots, p(n)$ adalah benar daripada hipotesis yang menyatakan bahwa $p(n)$ benar. Prinsip induksi kuat memungkinkan kita mendapatkan kesimpulan yang sama walaupun menggunakan perumpamaan yang lebih banyak.

\section{Contoh 3.10}


Bilangan bulat positif dikatakan bilangan prima jika dan hanya jika bilangan bulat tersebut habis dibagi 1 dan dirinya sendiri. Buktikan bahwa setiap bilangan bulat positif $n(n \geq 2)$ dapat dinyatakan sebagai perkalian dari (satu atau lebih) bilangan prima. Buktikan dengan prinsip induksi kuat.

Penyelesaian:

Andaikan $p(n)$ adalah proposisi dengan setiap bilangan bulat positif $n(n \geq 2)$ dapat dinyatakan sebagai perkalian dari (satu atau lebih) bilangan prima.

i. Basis induksi

$p$ (2) benar, karena 2 adalah bilangan prima dan 2 habis dibagi dengan 1 dan dirinya sendiri.

ii. Langkah induksi

Andaikan $p(n)$ benar, asumsikan bilangan $2,3, \ldots, n$ dapat dinyatakan sebagai perkalian (satu atau lebih) bilangan prima (hipotesis induksi). Maka tunjukkan bahwa $p(n+1)$ benar, yaitu $n+1$ juga dapat dinyatakan sebagai perkalian bilangan prima:

Jika $n+1$ sendiri bilangan prima, maka jelas bilangan tersebut dapat dinyatakan sebagai perkalian satu atau lebih bilangan prima. Jika $n+1$ bukan bilangan prima, maka terdapat bilangan bulat positif $a$ yang membagi habis $n+1$ tanpa sisa. Sehingga diperoleh:

$$
(n+1) / a=b \quad \text { atau } \quad(n+1)=a b
$$

Menurut hipotesis induksi, $a$ dan $b$ dapat dinyatakan sebagai perkalian satu atau lebih bilangan prima. Hal ini menunjukkan $(n+1)$ jelas dapat dinyatakan sebagai perkalian bilangan prima, karena $(n+1)=$ $a b$.

Karena kedua langkah sudah ditunjukkan benar, maka terbukti bahwa setiap bilangan bulat positif $n(n \geq 2)$ dapat dinyatakan sebagai perkalian dari (satu atau lebih) 
bilangan prima.

\section{Prinsip Induksi Secara Umum}

Definisi 4.1. Relasi biner " $<$ " pada himpunan $X$ dikatakan terurut dengan baik bila memiliki properti berikut:

i) Diberikan $x, y, z \in X$, jika $x<y$ dan $y<z$, maka $x<z$

ii) Diberikan $x, y, z \in X$. Salah satu dari kemungkinan ini benar: $x<y$ atau $y<x$ atau $x=y$.

iii) Apabila $A$ adalah himpunan bagian tidak kosong dari $X$, terdapat elemen $x \in A$ sedemikian hingga $x \leq y$ untuk semua $y \in A$. Dapat dikatakan bahwa setiap himpunan bagian tidak kosong dari $X$ memiliki "elemen terkecil".

Bentuk induksi secara umum dapat dinyatakan sebagai berikut:

Andaikan $X$ terurut oleh "<", dan $p(x)$ adalah pernyataan dari elemen $x$ dari $X$. Maka untuk membuktikan bahwa $p(x)$ benar untuk semua $x \in X$, tunjukkan bahwa:

i. $\quad p\left(x_{0}\right)$ benar, $x_{0}$ adalah elemen terkecil di dalam $X$, dan

ii. Jika $p(y)$ benar untuk $y<x$, maka $p(x)$ juga benar untuk setiap $x>x_{0}$ di dalam $X$,

sehingga $p(x)$ benar untuk semua $x \in X$.

Contoh 3.11

Perhatikan barisan bilangan di bawah ini:

$S_{m, n}=\left\{\begin{array}{cc}1 & \text { jika } m=0 \text { dan } n=0 \\ S_{m-1, n}+1 & \text { jika } n=0 \\ S_{m, n-1}+1 & \text { jika } n \neq 0\end{array}\right.$

Sebagai contoh,

$$
\begin{array}{ll}
S_{0,0}=0 & S_{1,0}=S_{0,0}+1=0+1=1 \\
S_{0,1}=S_{0,0}+1=1 & S_{1,1}=S_{1,0}+1=1+1=2 \\
S_{2,0}=S_{1,0}+1=2 & S_{2,1}=S_{2,0}+1=3, \ldots
\end{array}
$$

Buktikanlah dengan induksi matematika bahwa untuk 
pasangan tidak negatif $m$ dan $n, S_{m, n}=m+n$.

Penyelesaian:

i. Basis induksi

Karena $(0,0)$ adalah elemen terkecil di dalam $X$, maka $S_{0,0}=0+0=0$. Ini benar dari definisi $S_{0,0}$.

ii. Langkah induksi

Buktikan untuk semua $(m, n)>(0,0)$ di dalam $X$ bahwa jika $S_{m^{\prime}, n^{\prime}}=m^{\prime}+n^{\prime}$ benar untuk semua $\left(m^{\prime}, n^{\prime}\right)<$ $(m, n)$ maka $S_{m, n}=m+n$ juga benar.

Andaikan bahwa $S_{m^{\prime}, n^{\prime}}=m^{\prime}+n^{\prime}$ adalah benar untuk semua $\left(m^{\prime}, n^{\prime}\right)<(m, n)$.

Langkah selanjutnya tunjukkan bahwa $S_{m, n}=m+n$, baik untuk $n=0$ atau $n \neq 0$.

Kasus 1: Jika $n=0$,maka dari definisi $S_{m, n}=S_{m-1, n}+1$

Karena $(m-1, n)<(m, n)$, maka dari hipotesis induksi,

$$
\begin{aligned}
& S_{m-1, n}=(m-1)+n \text { sehingga } \\
& \quad S_{m, n}=S_{m-1, n}+1=(m-1)+n+1=m+
\end{aligned}
$$

$n$.

Kasus 2: Jika $n \neq 0$, maka dari definisi $S_{m, n}=S_{m, n-1}+1$ Karena $(m, n-1)<(m, n)$, maka dari hipotesis induksi,

$$
\begin{aligned}
S_{m, n-1} & =m+(n-1) \text { sehingga } \\
S_{m, n} & =S_{m, n-1}+1=m+(n-1)+1=m+
\end{aligned}
$$
$n$.

Karena kedua langkah tersebut dapat menunjukkan kebnarannya, maka terbukti bahwa untuk pasangan tidak negatif $m$ dan $n, S_{m, n}=m+n$.

\section{KESIMPULAN}

1. Induksi matematika adalah metode pembuktian suatu proposisi yang elemennya bilangan bulat yang bentuknya baku. 
2. Prinsip induksi sederhana : Andaikan $p(n)$ adalah proposisi bilangan bulat positif dan untuk membuktikan bahwa $p(n)$ adalah benar untuk semua bilangan bulat positif $n$. Maka langkah-langkahnya adalah tunjukkan bahwa $p(n)$ benar dan jika $p(n)$ benar, maka $p(n+1)$ juga benar untuk setiap $n \geq 1$.

3. Prinsip induksi kuat: Misalkan $\mathrm{p}(\mathrm{n})$ adalah pernyataan tentang bilangan bulat dan untuk membuktikan bahwa $p(n)$ benar untuk semua bilangan bulat $n \geq n_{0}$, tunjukkan bahwa: $p\left(n_{0}\right)$ benar dan jika $\mathrm{p}\left(\mathrm{n}_{0}\right), \mathrm{p}\left(\mathrm{n}_{0}+1\right), \ldots, \mathrm{p}(\mathrm{n})$ benar, maka $\mathrm{p}(\mathrm{n}+1)$ juga benar untuk setiap bilangan bulat $n \geq n_{0}$, sehingga $p(n)$ benar untuk semua bilangan bulat $\mathrm{n} \geq \mathrm{n}_{0}$.

\section{LATIHAN SOAL}

1. Buktikan dengan induksi matematika bahwa $n^{5}-n$ habis dibagi 5 untuk $n$ bilangan bulat positif!

2. Untuk biaya pos berapa saja yang dapat menggunakan perangko senilai $\$ 5$ dan $\$ 6$ ? Buktikan jawaban anda dengan induksi matematika!

3. Di dalam sebuah pesta, setiap tamu berjabat tangan dengan tamu lainnya hanya sekali saja. Buktikan dengan induksi matematika bahwa jika ada $n$ orang tamu maka jumlah jabat tangan yang terjadi adalah $(n-1) / 2$ !

4. Sebuah ATM sebuah bank hanya tersedia pecahan uang Rp.20.000,00 dan Rp. 50.000,00. Kelipatan uang berapakah yang dapat dikeluarkan oleh ATM tersebut? Buktikan jawaban anda dengan induksi matematika!

5. Ketika n pasangan tamu tiba di pesta, mereka disambut oleh tua dan nyonya rumah di pintu. Setelah saling berjabat tangan, tuan rumah bertanya kepada para tamu maupun istrinya untuk mengatakan berapa kali mereka masing-masing telah berjabat 
tangan. la memperoleh $2 \mathrm{n}+1$ jawaban yang berbeda. Jika tidak seorang pun berjabat tangan dengan istri maupun suaminya sendiri, berapa kalikah rumah telah berjabat tangan?Buktikan jawaban anda dengan induksimatematika! 


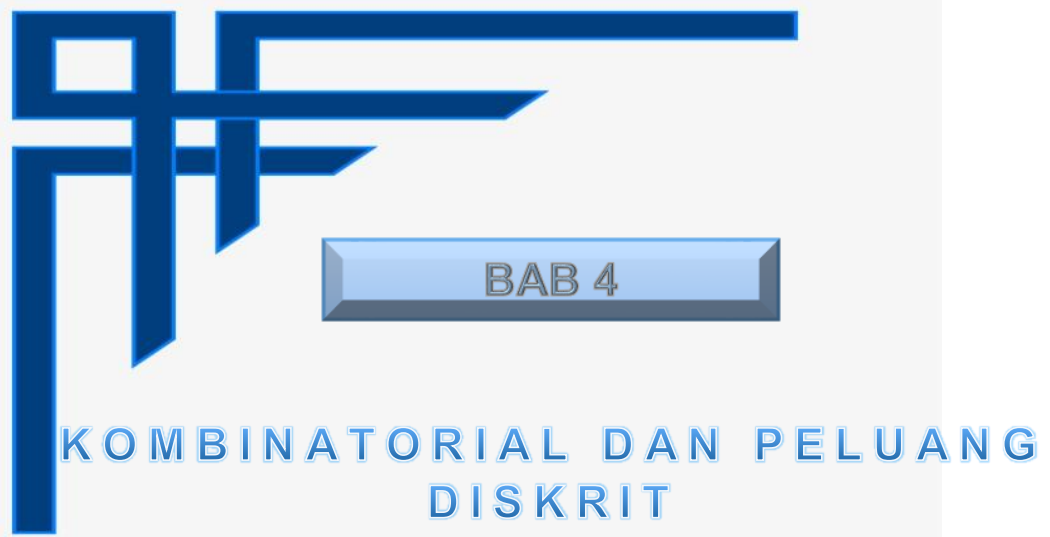

CAPAIAN PEMBELAJARAN:

1. Mahasiswa mampu memahami konsep peluang, kombinasi dan peluang diskrit

2. Mahasiswa mampu mengaplikasikan konsep peluang, kombinasi dan peluang diskrit 
Salah satu cabang matematika yang mempelajari pengaturan objek-objek adalah kombinatorial. Kombinatorial ini berguna untuk menghitung jumlah penyusunan objek-objek tanpa harus menghitung semua kemungkinan susunannya. Contoh-contoh masalah yang dapat diselesaikan dengan kombinatorial adalah sebagai berikut:

i) Dalam suatu sistem komputer terdapat sandi atau password yang terdiri dari 5 sampai 7 karakter. Ada berapa banyak sandi atau password yang bisa disusun dimana setiap karakter boleh dalam bentuk huruf dengan syarat huruf besar dan huruf kecil tidak dibedakan dan boleh dalam bentuk angka?

ii) Di suatu negara plat nomor suatu kendaraan bermotor terdiri dari 4 angka dan 2 huruf. Ada berapa banyak plat nomor kendaraan bermotor yang bisa disusun jika angka pertama tidak boleh 0 ?

Cara yang paling sederhana untuk menyelesaikan permasalahan tersebut adalah dengan mengenumerasi semua kemungkinan jawabannya. Mengenumerasi artinya menghitung satu persatu setiap kemungkinan jawaban. Mengenumerasi setiap jawaban mungkin dilakukan jika permasalahan dengan jumlah objek sedikit. Tetapi untuk permasalah dengan jumlah objek yang banyak, cara mengenumerasi setiap jawaban pasti membutuhkan waktu yang lama dan ketelitian. Maka cara kombinatorial sangat diperlukan untuk menyelesaikan permasalahan seperti contoh di atas.

\section{A. Kaidah Dasar Menghitung}

Kaidah dasar menghitung merupakan suatu cara untuk menghitung semua kemungkinan pengaturan objek. Dua kaidah 
dasar yang digunakan dalam kombinatorial untuk memecahkan persoalan menghitung adalah sebagai berikut:

\section{Kaidah perkalian}

Bila percobaan 1 mempunyai $p$ hasil percobaan yang mungkin terjadi, percobaan 2 mempunyai $q$ hasil percobaan yang mungkin terjadi, maka bila percobaan 1 dan percobaan 2 dilakukan, maka terdapat $p \times q$ hasil percobaan.

\section{Kaidah penjumlahan}

Bila percobaan 1 mempunyai $p$ hasil percobaan yang mungkin terjadi, percobaan 2 mempunyai $q$ hasil percobaan yang mungkin terjadi, maka jika hanya 1 percobaan saja yang dilakukan (percobaan 1 atau percobaan 2), terdapat $p+q$ hasil percobaan.

Perhatikan dua kata yang digaris bawahi yaitu dan serta atau. Kedua kata tersebut adalah kata kunci untuk mengidentifikasi apakah suatu persoalan menghitung tersebut dapat diselesaikan dengan kaidah perkalian atau kaidah penjumlahan.

\section{Contoh 4.1}

Dari lima orang mahasiswa baru yaitu Ana, Budi, Citra, Dina, dan Edi merupakan mahasiswa jurusan Informatika dengan pembimbing skripsi yang sama. Setiap orang harus memilih satu tema skripsi dalam satu orang pembimbing skripsi yaitu game, aplikasi, dan kecerdasan buatan. Berapa banyak pasangan mahasiswa dan tema skripsi yang dapat dipilih?

\section{Penyelesaian:}

Untuk menentukan jumlah pasangan mahasiswa dan tema skripsi yang dapat dipilih dapat menggunakan diagram pohon.

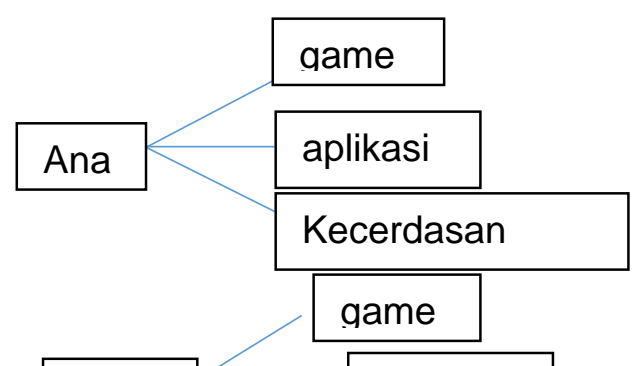


game

\section{Edi}

Berdasarkan diagram pohon di atas, kemungkinan semua pasangan mahasiswa dan tema skripsi yaitu:

buatan
Ana, game
Ana, aplikasi
Ana,kecerdasan

Budi, game

Budi, aplikasi

Budi,kecerdasan buatan

Citra, game

Citra, aplikasi

Citra, kecerdasan

buatan

Dina, game

buatan

Edi, game

Dina, aplikasi

Dina,kecerdasan

buatan

Edi, aplikasi

Edi, kecerdasan

Semuanya ada 15 pasang.

Ada 5 kemungkinan memilih mahasiswa yaitu Ana, Budi, Citra, Dina dan Edi. Ada 3 kemungkinan memilih tema skripsi yaitu game,aplikasi, dan kecerdasan buatan. Dengan menggunakan kaidah perkalian, jumlah kemungkinan pasangan mahasiswa dan tema skripsi yang dapat diilih adalah $5 \times 3=15$ pasang. 
Dalam lemari baju Rani terdapat 4 macam baju bawahan yaitu celana panjang, celana pendek, rok panjang, dan rok pendek serta 5 macam baju atasan yang berbeda warna. Ada berapa cara memilih satu baju bawahan dan satu baju atasan yang bisa dipakai Rani?

Penyelesaian:

Ada 4 kemungkinan memilih satu baju bawahan dan ada 5 kemungkinan untuk memilih satu baju atasan. Jika hanya satu pasang baju yang harus dipilih yaitu satu baju bawahan dan satu baju atasan, maka jumlah kemungkinan pasangan baju yang dapat dipakai Rani adalah $4 \times 5=20$ pasang baju.

\section{Contoh 4.3}

Jabatan ketua himpunan Informatika dapat diduduki oleh mahasiswa angkatan tahun 2018 atau angkatan tahun 2019. Jika terdapat 40 orang mahasiswa angkatan tahun 2018 dan 54 orang angkatan tahun 2019, ada berapa cara untuk memilih ketua himpunan?

Penyelesaian:

Jabatan yang ditawarkan hanya satu yaitu ketua himpunan yang dapat diduduki oleh salah seorang mahasiswa dari dua angkatan yang berbeda. Ada 40 cara memilih satu orang mahasiswa dari angkatan tahun 2018 dan ada 54 cara memilih satu orang dari angkatan tahun 2019, namun hanya satu orang dari kedua angkatan itu yang terpilih (angkatan 2018 atau angkatan 2019). Dalam permasalahan ini, hanya satu dari dua kejadian yang dilakukan, sehingga dapat diselesaikan dengan kaidah penjumlahan, jumlah cara memilih pejabat ketua himpunan tersebut sama dengan jumlah mahasiswa pada kedua angkatan yaitu $40+$ $54=94$ cara.

\section{Contoh 4.4}

Suatu travel agen memiliki beberapa pilihan destinasi wisata di Jawa Timur yang terdiri atas 5 wisata pantai yaitu Pantai Gemah, Pantai Papuma, Pantai Pulau Merah, Pantai Klayar dan Pantai Tiga Warna serta 3 wisata gunung yaitu 
Gunung Bromo, Gunung Semeru, dan Gunung Ijen. Berapa jumlah cara memilih satu destinasi wisata (tidak peduli wisata pantai atau wisata gunung)?

Penyelesaian:

Ada 5 kemungkinan memilih satu wisata pantai dan ada 3 kemungkinan memilih satu wisata gunung. Jika hanya satu destinasi wisata yang harus dipilih (pantai atau gunung), maka jumlah kemungkinan destinasi wisata yang dapat dipilih adalah

$5+3=8$.

\section{Perluasan kaidah menghitung}

Kaidah perkalian dan kaidah penjumlahan dapat terjadi hingga lebih dari dua buah percobaan. Jika $n$ buah percobaan masing-masing mempunyai $p_{1}, p_{2}, \ldots, p_{n}$ hasil percobaan yang mungkin terjadi dengan setiap $p_{i}$ tidak tergantung pada pilihan sebelumnya, maka jumlah hasil percobaan yang mungkin terjadi adalah:

i) $p_{1} x p_{2} x \quad \ldots x \quad p_{n}$ untuk kaidah perkalian

ii) $p_{1}+p_{2}+\ldots+p_{n}$ untuk kaidah penjumlahan

\section{Contoh 4.5}

Perpustakaan prodi Informatika memiliki 10 buah buku Kalkulus, 8 buah buku Matematika Diskrit, dan 6 buah buku Aljabar Linier. Masing-masing buku berbeda penulisnya. Berapa jumlah cara memilih (a) 3 buah buku, masingmasing dari tiap mata kuliah yang berbeda, dan (b) 1 buah buku (sembarang mata kuliah)?

Penyelesaian:

a. Jumlah cara memilih 3 buah buku, masing-masing dari tiap mata kuliah adalah $10 \times 8 \times 6=480$ cara

b. Jumlah cara memilih 1 buah buku (sembarang mata kuliah) = $10+8+6=24$ cara

Beberapa persoalan kombinatorial yang lebih kompleks dapat diselesaikan dengan menggunakan kaidah dasar menghitung. Tetapi ada beberapa persoalan yang tidak dapat diselesaikan dengan satu kaidah saja, tetapi harus 
menggunakan dua kaidah sekaligus seperti contoh di bawah ini.

\section{Contoh 4.6}

Dalam suatu sistem komputer terdapat sandi atau password yang terdiri dari 5 sampai 7 karakter. Ada berapa banyak sandi atau password yang bisa disusun dimana setiap karakter boleh dalam bentuk huruf dengan syarat huruf besar dan huruf kecil tidak dibedakan dan boleh dalam bentuk angka?

Penyelesaian:

Jumlah huruf alphabet ada 26 (A-Z) dan jumlah angka ada 10 (0-9). Sehingga keseluruhan karakter ada $26+10=36$ karakter. Masing-masing huruf atau angka dapat menempati dalam suatu sandi atau password.

Untuk kata sandi dengan 5 karakter, kemungkinannya adalah:

(36)(36)(36)(36)(36) $=36^{5}=60.466 .176$

Untuk kata sandi dengan 6 karakter, kemungkinannya adalah:

$(36)(36)(36)(36)(36)(36)=36^{6}=2.176 .782 .336$

Dan untuk kata sandi dengan 7 karakter, kemungkinannya adalah:

$(36)(36)(36)(36)(36)(36)(36)=36^{7}=78.364 .164 .096$

Sehingga menurut kaidah penjumlahan, diperoleh jumlah seluruh kata sandi yang dapat disusun adalah:

$60.466 .176+2.176 .782 .336+78.364 .164 .096=$ 80.601 .412 .608

\section{Contoh 4.7}

Di suatu negara plat nomor suatu kendaraan bermotor terdiri dari 4 angka dan 2 huruf. Ada berapa banyak plat nomor kendaraan bermotor yang bisa disusun jika angka pertama tidak boleh 0 ?

Penyelesaian:

Ada 6 karakter dalam susunan plat nomor kendaraan bermotor yaitu 4 angka dan 2 huruf: _. _ _ _ _. Huruf dan angka boleh 
berulang (kecuali jika ada syarat bahwa pengulangan tidak dibolehkan). Ada 9 pilihan angka untuk mengisi karakter pertama (karena 0 tidak dibolehkan). Karakter kedua, ketiga, dan keempat masing-masing ada 10 pilihan angka. Karakter kelima dapat diisi dengan 26 pilihan huruf dan karakter keenam dapat diisi dengan 26 pilihan huruf juga. Sehingga dengan menggunakan kaidah perkalian, jumlah nomor plat mobil yang dapat dibuat adalah :

$9 \times 10 \times 10 \times 10 \times 26 \times 26=6.084 .000$ plat nomor.

\section{B. Permutasi}

Sebelum kita membahas mengenai permutasi, ada baiknya untuk mengingat kembali faktorial.

Definisi 4.1. Fungsi faktorial didefinisikan sebagai:

$$
c !=\prod_{k=1}^{n} k, \text { untuk semua } n \geq 1
$$

Selain definisi tersebut, terdapat juga definisi secara rekursif, yang didefinisikan untuk $n \geq 0$

$$
n !=\left\{\begin{array}{cc}
n(n-1) ! & , \text { untuk } n \geq 1 \\
1 & , \text { untuk } n=0
\end{array}\right.
$$

Misalkan $n$ adalah bilangan bulat positif. Besaran $n$ faktorial (n!) didefinisikan sebagai hasil kali semua bilangan bulat antara $n$ hingga 1 . Untuk $n=0$ atau dengan kata lain 0 ! didefinisikan $=1$.

$$
\begin{aligned}
& n !=n .(n-1)(n-2) \ldots 1 \\
& 0 !=1
\end{aligned}
$$

Definisi 4.2. Permutasi adalah susunan yang dibentuk dari anggota suatu himpunan dengan mengambil seluruh atau sebagian anggota himpunan dan memberi arti pada urutan anggota dari susunan.

Ciri-ciri permutasi :

1. Urutan diperhatikan 
2. Perulangan tidak diperbolehkan

Definisi 4.3. Permutasi $r$ dari $n$ objek adalah banyaknya kemungkinan urutan $r$ buah objek yang dipilih dari $n$ buah objek, dengan $r \leq n$, sehingga setiap kemungkinan urutan tidak ada objek yang sama.

$$
P_{n, r}=\frac{n !}{(n-r) !}
$$

\section{Contoh 4.8}

Saat ujian akhir semester suatu kelas memiliki barisan kursi yang disusun per baris. Tiap baris ada 6 kursi. Apabila ada dua orang akan duduk bersebelahan, berapa banyak kemungkinan pengaturan tempat duduk dalam satu baris? Penyelesaian:

Orang pertama memiliki 6 pilihan kursi, dan orang kedua memiliki 5 pilihan kursi. Jadi banyak pengaturan tempat duduk adalah $6 \times 5=30$ atau

$$
P(6,2)=\frac{6 !}{(6-2) !}=\frac{6 !}{4 !}=6 \times 5=30 \text { cara }
$$

\section{Contoh 4.9}

Suatu string akan dibentuk dari 3 huruf dan 4 angka yang berbeda. Berapa banyak kemungkinan string yang dapat disusun?

Penyelesaian:

Ada 3 huruf yang disusun dari 26 huruf maka $P(26,3)$ dan ada 4 angka yang disusun dari 10 angka maka $P(10,4)$

Banyaknya kemungkinan string yang dapat disusun adalah:

$$
\begin{aligned}
P(24,3) \times P(10,4) & =\frac{24 !}{(24-3) !} \times \frac{10 !}{(10-4) !} \\
& =\frac{24 !}{21 !} \times \frac{10 !}{6 !} \\
& =61.205 .760
\end{aligned}
$$

Bila $r=n$, maka persamaan permutasinya: 


$$
P(n, n)=\frac{n !}{(n-n) !}=\frac{n !}{0 !}=\frac{n !}{1}=n !
$$

\section{Contoh 4.10}

Dari empat calon pengurus himpunan mahasiswa Informatika, berapa banyak susunan yang dapat terjadi untuk menentukan ketua, wakil ketua, sekretaris dan bendahara?

Penyelesaian :

Masalah tersebut merupakan masalah permutasi 4 objek dari 4 objek, sehingga:

$$
P(4,4)=\mathrm{n} !=4 \cdot 3 \cdot 2 \cdot 1=24
$$

Jadi ada 24 susunan calon pengurus himpunan mahasiswa Informatika.

\section{Permutasi $\mathbf{n}$ objek dari $\boldsymbol{n}$ objek dengan beberapa objek sama}

Ada $n$ objek yang beberapa diantaranya sama. Misalnya $n$ buah bola warna sama.

$$
\begin{aligned}
& n_{1} \text { bola diantaranya berwarna } 1 \\
& n_{2} \text { bola diantaranya berwarna } 2 \\
& \ldots \\
& n_{k} \text { bola diantaranya berwarna } k
\end{aligned}
$$

Sehingga $n_{1}+n_{2}+\ldots+n_{k}=n$. Bola-bola tersebut dimasukkan ke dalam $n$ buah kantong, masing-masing kantong berisi paling banyak 1 buah bola. Berapa banyak jumlah cara pengaturan $n$ buah bola ke dalam kantong-kantong tersebut?

Jika $n$ buah bola dianggap berbeda semua, maka banyak cara pengaturan $n$ buah bola ke dalam $n$ buah kantong adalah :

$$
P(n, n)=n !
$$

Karena tidak seluruh bola berbeda maka pengaturan $n$ buah 
bola:

$\mathrm{n}_{1}$ ! cara memasukkan bola berwarna 1

$\mathrm{n}_{2}$ ! cara memasukkan bola berwarna 2

$\mathrm{n}_{\mathrm{k}}$ ! cara memasukkan bola berwarna $\mathrm{k}$

Sehingga permutasi $n$ buah bola dikenal dengan permutasi bentuk umum :

$$
P\left(n: n_{1}, n_{2}, \ldots, n_{k}\right)=\frac{n !}{n_{1} ! n_{2} ! \ldots n_{k} !}
$$

\section{Contoh 4.11}

Berapa banyak susunan huruf berbeda yang dapat dibentuk dari kata MATEMATIKAWAN?

Penyelesaian :

Terdapat 13 huruf pada kata MATEMATIKAWAN, terdiri dari 2 huruf $M, 4$ huruf $A, 2$ huruf T, 1 huruf $I, 1$ huruf $E, 1$ huruf $K, 1$ huruf $W, 1$ huruf $N$

Banyak susunan huruf yang dapat dibuat adalah:

$$
P\left(n ; n_{1}, n_{2}, \ldots, n_{3}\right)=\frac{13 !}{2 ! 4 ! 2 !}=64.864 .800
$$

\section{Permutasi Melingkar}

Definisi 4.4. Permutasi melingkar dari $n$ objek adalah penyusunan objek-objek yang mengelilingi berbentuk suatu lingkaran. Jumlah susunan objek yang mengelilingi lingkaran adalah

$$
P=(\boldsymbol{n}-\mathbf{1}) !
$$




\section{Contoh 4.12}

Ada 10 orang akan melaksanakan rapat di meja yang berbentuk bundar. Berapa banyak cara mereka duduk mengelilingi meja tersebut?

Penyelesaian:

Satu orang dapat duduk di mana saja. Sembilan orang sisanya busa duduk dalam $9 \times 8 \times 7 \times 6 \times 5 \times 4 \times 3 \times 2 \times 1=9$ ! = 362.880 cara atau dengan rumus permutasi melingkar:

$$
P=(10-1) !=9 !=362.880
$$

\section{Kombinasi}

Definisi 4.5. Kombinasi $r$ elemen dari $n$ elemen adalah banyaknya pemilihan yang tidak terurut $r$ elemen yang diambil dari $n$ buah elemen.

$$
\boldsymbol{C}(\boldsymbol{n}, \boldsymbol{r})=\frac{\boldsymbol{n} !}{\boldsymbol{r} !(\boldsymbol{n}-\boldsymbol{r}) !}
$$

Istilah kombinasi dalam matematika kombinatorik berarti himpunan objek yang tidak mementingkan urutan. Kombinasi berbeda dengan permutasi yang mementingkan urutan objek.

\section{Contoh 4.13}

Ada berapa cara kita dapat memilih 3 dari 4 jenis buah $A=\{$ apel, mangga, jeruk, duku $\}$ ?

Penyelesaian:

Dari soal tersebut dapat diketahui bahwa urutan memilih 3 buah tersebut tidak dipermasalahkan, berarti ini adalah soal 
kombinasi.

Jadi jumlah cara memilih 3 dari 4 jenis buah adalah $C(4,3)=\frac{4 !}{3 !(4-3) !}=4$

Yaitu himpunan \{apel, mangga, jeruk\}, \{apel, mangga, duku\}, \{apel, jeruk, duku\} dan \{mangga, jeruk, duku\}.

\section{Contoh 4.14}

Berapa banyak cara menyusun menu nasi goreng 4 kali seminggu untuk sarapan pagi?

Penyelesaian:

Banyaknya cara pengaturan jadwal menu nasi goreng adalah $C(7,4)=\frac{7 !}{4 !(7-4) !}=35$ cara.

\section{Contoh 4.15}

Dari 10 mahasiswa Informatika angkatan 2020, berapa banyak cara membentuk sebuah tim yang mewakili perlombaan komputer yang beranggotakan 5 orang, sedemikian hingga:

a. Adi selalu masuk dalam tim

b. Adi tidak termasuk dalam tim

c. Adi selalu masuk dalam tim, tetapi Budi tidak

d. Adi dan Budi masuk dalam tim

Penyelesaian:

a. Masukkan Adi ke dalam perwakilan sehingga sekarang tersisa 9 orang mahasiswa. Dari 9 orang ini, pilih 4 orang lagi sebagai perwakilan. Jadi ada $C(9,4)=126$ cara untuk membentuk perwakilan yang beranggotakan 5 orang sedemikian hingga Adi selalu masuk di dalamnya.

b. Keluarkan Adi dari kelompok mahasiswa, sehingga sekarang tersisa 9 orang mahasiswa. Dari 9 orang ini akan dipilih 5 orang sebagai anggota perwakilan. Jadi ada $C(9,5)=126$ cara 
untuk membentuk perwakilan yang beranggotakan 5 orang sedemikian hingga Adi tidak masuk di dalamnya.

c. Keluarkan B dari kelompok mahasiswa, sehingga tersisa 9 orang. Masukkan Adi ke dalam perwakilan sehingga tersisa 8 orang. Dari 8 orang ini akan dipilih 4 orang lagi sebagai anggota perwakilan. Jadi ada $\mathrm{C}(8,4)=70$ cara untuk membentuk perwakilan yang beranggotakan 5 orang sedemikian hingga Adi termasuk di dalamnya tetapi Budi tidak.

d. Masukkan Adi dan Budi ke dalam perwakilan sehingga tersisa 8 orang mahasiswa. Dari 8 orang ini, pilih 3 orang lagi sebagai anggota perwakilan. Jadi ada $\mathrm{C}(8,3)=56$ cara untuk membentuk perwakilan yang beranggotakan 5 sedemikian hingga Adi dan Budi selalu termasuk di dalamnya.

\section{Contoh 4.16}

Sebuah klub beranggotakan 10 pria dan 8 wanita. Berapa banyak cara memilih panitia yang terdiri dari 6 orang dengan jumlah pria lebih banyak daripada wanita?

Penyelesaian:

Panitia: 6 orang, jumlah pria lebih banyak daripada jumlah wanita Panitia terdiri dari 5 pria, 1 wanita $\rightarrow \mathrm{C}(10,5) \times \mathrm{C}(8,1)$ Panitia terdiri dari 4 pria, 2 wanita $\rightarrow \mathrm{C}(10,4) \times \mathrm{C}(8,2)$ Panitia terdiri dari 6 pria, 0 wanita $\rightarrow \mathrm{C}(10,6) \times \mathrm{C}(8,0)$ Jumlah cara pembentukan panitia seluruhnya $=(C(10,5) \times C(8,1))$ $+(C(10,4) \times C(8,2))+(C(10,6) \times C(8,0))$.

\section{Kombinasi Pengulangan}


Kombinasi pengulangan adalah jumlah kombinasi yang membolehkan adanya pengulangan elemen $\rightarrow n$ buah objek akan diambil $r$ buah objek dengan pengulangan diperbolehkan.

$$
C(n+r-1, \quad r)
$$

\section{Contoh 4.17}

Berapa banyak hasil berbeda yang mungkin terjadi dari pelemparan 4 buah dadu bersamaan ?

Penyelesaian :

Diketahui :

$\mathrm{n}=6$

$$
r=4
$$

Sehingga banyaknya kemungkinan hasil berbeda yang terjadi adalah:

$$
\begin{aligned}
C(n+r-1, r) & =C(6+4-1,4) \\
& =C(9,4) \\
& =126 \text { cara }
\end{aligned}
$$

\section{Contoh 4.18}

Berapa banyak cara pembagian yang dapat dilakukan jika ada 32 permen dan 24 coklat dibagikan kepada 4 anak, tiap anak boleh mengambil lebih dari 1 buah permen atau coklat, atau tidak sama sekali?

Penyelesaian :

Diketahui :

$$
\begin{aligned}
& n=4 \text { orang anak } \\
& r_{1}=32 \text { buah permen } \\
& r_{2}=24 \text { buah coklat }
\end{aligned}
$$

32 buah permen dibagikan kepada 4 anak

$$
C(n+r-1, r)=C(4+32-1,32)=C(35,32)
$$

24 buah coklat dibagikan kepada 4 orang anak 


$$
C(n+r-1, r)=C(4+24-1,24)=C(27,24)
$$

Jika setiap anak boleh mendapat permen dan coklat maka jumlah cara pembagiannya adalah :

$$
\begin{aligned}
C(35,32) \times C(27,24) & =6.545 \times 2.691 \\
& =17.612 .595 \text { cara }
\end{aligned}
$$

\section{Kombinasi Bentuk Umum}

Jika $S$ adalah himpunan ganda dengan $n$ buah objek yang di dalamnya terdiri dari $k$ jenis objek berbeda dan tiap objek memiliki multiplisitas $n_{1}, n_{2}, \ldots, n_{k}$ (jumlah objek seluruhnya $n_{1}+n_{2}+\ldots+n_{k}=n$ ) maka jumlah cara menyusun seluruh objek adalah :

$$
C\left(n: n_{1}, n_{2}, \ldots, n_{k}\right)=\frac{n !}{n_{1} ! n_{2} ! \ldots n_{k} !}
$$

Sehingga bisa dikatakan bahwa :

$$
P\left(n: n_{1}, n_{2}, \ldots, n_{k}\right)=C\left(n: n_{1}, n_{2}, \ldots, n_{k}\right)=\frac{n !}{n_{1} ! n_{2} ! \ldots n_{k} !}
$$

\section{Contoh 4.19}

Berapa jumlah cara pengaturan lampu jika ada 12 buah lampu berwarna yang terdiri dari 6 warna hijau, 4 warna kuning, dan 7 warna merah muda akan dipasang pada 18 buah soket dalam sebuah baris (sisanya 6 buah soket dibiarkan kosong)?

Penyelesaian:

Diketahui: $\mathrm{n}=20 ; \mathrm{n}_{1}=6, \mathrm{n}_{2}=4, \mathrm{n}_{3}=7$, dan $\mathrm{n}_{4}=3$ (soket kosong)

Jumlah cara pengaturan lampu $=P(20: 6,4,7,3)=\frac{18 !}{6 ! 4 ! 7 ! 3 !}$ cara

\section{E. Peluang Diskrit}


Kombinatorial dan peluang diskrit terkait erat. Teori peluang banyak menggunakan konsep-konsep di dalam kombinatorial. Kombinatorial didasarkan pada percobaan. Hasil percobaan diamati dan jumlah semua kemungkinannya dihitung. Himpunan semua kemungkinan hasi percobaan dinamakan ruang sampel dari percobaan yang telah dilakukan. Setiap hasil percobaan di dalam ruang sampel disebut titik sampel.

Definisi 4.6. Misalkan $x_{i}$ adalah sebuah titik sampel di dalam ruang sampel $S$. Peluang bagi $x_{i}$ adalah ukuran kemungkinan terjadinya atau munculnya $x_{i}$ di antara titik-titik sampel yang lain di dalam $S$.

Peluang diskrit mempunyai sifat sebagai berikut:

1. $0 \leq p\left(x_{i}\right) \leq 1$, yaitu nilai peluang berada di antara sama dengan 0 dan sama dengan 1

2. $\sum_{i=1}^{|S|} p\left(x_{i}\right)=1$, yaitu banyaknya peluang di semua ruang Sampel adalah 1

Suatu kejadian dikatakan terjadi jika salah satu dari titik sampel di dalam kejadian tersebut terjadi. Kejadian disimbolkan dengan A. Peluang terjadinya suatu kejadian didefinisikan sebagai berikut:

Definisi 4.7. Peluang kejadian A dalam ruang sampel $S$ adalah

$$
P(A)=\frac{|A|}{|S|}
$$

\section{Contoh 4.20}

Pada pelemparan dadu, $S=\{1,2,3,4,5,6\}$. Berapa peluang munculnya bilangan prima?

Penyelesaian: 
$S=\{1,2,3,4,5,6\},|S|=6$

kejadian munculnya bilangan prima adalah

$\mathrm{A}=\{2,3,5\}, \quad|A|=3$

Peluang munculnya bilangan prima adalah $3 / 6=1 / 2$.

\section{Contoh 4.21}

Dari seperangkat kartu bridge akan diambil satu kartu berturutturut sebanyak 2 kali tanpa pengembalian. Berapa peluang terambilnya kartu As?

Penyelesaian:

Jumlah kartu bridge ada 52, $|\mathrm{S}|=52$

Jumlah kartu As ada 4, $\mid$ As $\mid=4$

Pengambilan 1: $P\left|A s_{1}\right|=\frac{4}{52}$

Pengambilan 2: $P\left|A s_{2}\right|=\frac{3}{51}$

Sehingga peluang terambilnya kartu $A s=\frac{4}{52} \times \frac{3}{51}=0,0045$

Peluang diskrit menggunakan aturan-aturan pada teori himpunan. Misalkan dua buah himpunan yaitu kejadian $A$ dan kejadian $B$ dalam ruang sampel $S$ :

1. Peluang terjadinya kejadian A dan B adalah:

$$
p(A \cap B)=\sum_{x_{i} \in A \cap B} p\left(x_{i}\right)
$$

2. Peluang terjadinya kejadian $A$ atau $B$ adalah:

$$
p(A \cup B)=\sum_{x_{i} \in A \cup B} p\left(x_{i}\right)
$$

3. Peluang terjadinya kejadian A tetapi B tidak adalah:

$$
p(A-B)=\sum_{x_{i} \in A-B} p\left(x_{i}\right)
$$

4. Peluang terjadinya salah satu kejadian dari A dan B namun bukan keduanya adalah: 


$$
p(A \oplus \mathrm{B})=\sum_{x_{i} \in A \oplus \mathrm{B}} p\left(x_{i}\right)
$$

5. Peluang kejadian $\mathrm{A}$ komplemen adalah:

\section{Contoh 4.22}

$$
p\left(A^{c}\right)=1-p(A)
$$

Suatu forum diskusi dihadiri 100 orang mahasiswa yang terdiri dari 80 orang lai-laki dan 20 orang perempuan. Mahasiswa laki-laki yang memakai jaket almamater ada 35 orang (lja) dan 45 orang tidak memakai jaket almamater (Itja). Sedangkan untuk mahasiswa perempuan terdapat 8 orang yang memakai jaket almamater (pja) dan 12 orang yang tidak memakai jaket tersebut (ptja). Berapa peluang salah seorang mahasiswa terpilih untuk menjadi notulen jika:

a. mahasiswa laki-laki yang memakai almamater

b. mahasiswa laki-laki atau mahasiswa perempuan yang memakai jaket almamater

c. mahasiswa laki-laki yang tidak memakai jaket almamater atau mahasiswa perempuan yang memakai jaket almamater

d. mahasiswa laki-laki tetapi tidak memakai jaket

Penyelesaian:

$$
\begin{array}{ll}
\mathrm{p}(\text { lja })=35 / 100=0,35 ; & \mathrm{p}(\text { Itja })=45 / 100=0,45 \\
\mathrm{p}(\text { pja })=8 / 100=0,08 ; & \mathrm{p}(\text { ptja })=12 / 100=0,12
\end{array}
$$

a. $\quad p(A \cap B)=0,35$

b. $p(A \cup B)=0,35+0,45+0,08=0,88$

c. $p(A \oplus \mathrm{B})=0,45+0,12=0,57$

d. $p(A-B)=0,45$

\section{Contoh 4.23}

Di antara 1-100, berapa peluang memilih secara acak sebuah bilangan yang habis dibagi 2 atau 5 ?

Penyelesaian:

Misalkan:

$\mathrm{A}=$ kejadian bilangan bulat yang dipilih habis dibagi 2 
$\mathrm{B}=$ kejadian bilangan bulat yang dipilih habis dibagi 5

$A \cap B$ menyatakan kejadian bilangan bulat yang dipilih habis dibagi 2 dan 5 (KPK dari 2 dan 5 adalah 10)

$A \cup B$ menyatakan kejadian bilangan bulat yang dipilih habis dibagi 2 atau 5 .

$|A|=\lfloor 100 / 2\rfloor=50$

$|B|=\lfloor 100 / 5\rfloor=20$

$|A \cap B|=\lfloor 100 / 10\rfloor=10$

Maka

$p(A \cup B)=p(A)+p(B)-p(A \cap B)=\frac{50}{100}+\frac{20}{100}-\frac{10}{100}=0,6$.

\section{KESIMPULAN}

1. Kaidah dasar menghitung merupakan suatu cara untuk menghitung semua kemungkinan pengaturan objek.

2. Jika $n$ buah percobaan masing-masing mempunyai $p_{1}, p_{2}, \ldots, p_{n}$ hasil percobaan yang mungkin terjadi dengan setiap $p_{i}$ tidak tergantung pada pilihan sebelumnya, maka jumlah hasil percobaan yang mungkin terjadi adalah:

$i p_{1} x p_{2} x \quad \ldots x p_{n}$ untuk kaidah perkalian

ii $p_{1}+p_{2}+\ldots+p_{n}$ untuk kaidah penjumlahan

3. Fungsi faktorial didefinisikan sebagai $c !=\prod_{k=1}^{n} k$, untuk semua $n \geq 1$

4. Permutasi $r$ dari $n$ objek adalah banyaknya kemungkinan urutan $r$ buah objek yang dipilih dari $n$ buah objek, dengan $r \leq n$.

$$
\boldsymbol{P}_{n, \boldsymbol{r}}=\frac{\boldsymbol{n} !}{(\boldsymbol{n}-\boldsymbol{r}) !}
$$

5. Permutasi n objek dari $n$ objek dengan beberapa objek sama $P\left(n: n_{1}, n_{2}, \ldots, n_{k}\right)=\frac{n !}{n_{1} ! n_{2} ! \ldots n_{k} !}$

6. Permutasi melingkar dari $n$ objek adalah penyusunan objekobjek yang mengelilingi berbentuk suatu lingkaran. 


$$
\boldsymbol{P}=(\boldsymbol{n}-\mathbf{1}) !
$$

7. Kombinasi $r$ elemen dari $n$ elemen adalah banyaknya pemilihan yang tidak terurut $r$ elemen yang diambil dari $n$ buah elemen. $\boldsymbol{C}(\boldsymbol{n}, \boldsymbol{r})=\frac{\boldsymbol{n} !}{\boldsymbol{r} !(\boldsymbol{n}-\boldsymbol{r}) !}$

8. Kombinasi pengulangan adalah jumlah kombinasi yang membolehkan adanya pengulangan elemen $\rightarrow n$ buah objek akan diambil $r$ buah objek dengan pengulangan diperbolehkan $C(n+$ $r-1, r)$

9. Misalkan $x_{i}$ adalah sebuah titik sampel di dalam ruang sampel $S$. Peluang bagi $x_{i}$ adalah ukuran kemungkinan terjadinya atau munculnya $x_{i}$ di antara titik-titik sampel yang lain di dalam $S$.

10. Peluang kejadian $\mathrm{A}$ dalam ruang sampel $\mathrm{S}$ adalah $\boldsymbol{P}(\boldsymbol{A})=$ $\frac{|A|}{|S|}$

\section{LATIHAN SOAL}

1. Berapa banyak cara menyusun 6 digit nomor telepon dengan syarat angka pertama tidak boleh 0 dan boleh berulang?

2. Dalam ujian akhir Kalkulus terdapat 5 soal. Berapa banyak cara pemberian nilai pada setiap soal jika jumlah nilai keseluruhan soal adalah 100 dan setiap soal mempunyai nilai paling sedikit 2? (tidak perlu dicari hasil akhirnya)

3. Tersedia 8 angka: 1, 2, 3, 4, 5, 6, 7, 8. Berapa jumlah penyusunan bilangan yang terdiri dari 4 angka jika:
a. Tidak ada angka yang diulang
b. Boleh ada angka yang diulang
c. Lebih dari 3000
d. $2000-5000$ 
4. Sebuah mobil mempunyai 4 tempat duduk. Berapa banyak cara 3 orang duduk jika diandaikan satu orang harus duduk di kursi sopir?

5. Suatu universitas akan mengirimkan 100 orang mahasiswa ke 5 desa untuk kegiatan KKN, masing-masing desa mempunyai kuota 20 orang mahasiswa. Berapa banyak cara pembagian mahasiswa tersebut?

6. Tentukan berapa banyak cara memasang 10 pesawat telepon jika:

a. Pesawat telepon sama di 12 kamar hotel

b. Pesawat telepon terdiri dari 4 warna merah, 3 warna putih dan 3 warna hijau di 12 kamar hotel

7. Fakultas Teknik akan mengadakan seminar nasional. Untuk itu akan dibentuk panitia yang terdiri dari 4 orang. Panitia tersebut akan dipilih dari 6 orang mahasiswa Informatika dan 8 orang mahasiswa Teknik Elektro. Berapa banyak cara membentuk panitia jika:

a. Jurusan tidak dibatasi

b. Semua anggota panitia harus dari jurusan Informatika

c. Semua anggota panitia harus dari jurusan Teknik Elektro

d. Semua anggota panitia harus dari jurusan yang sama

e. 2 orang mahasiswa per jurusan harus mewakili

8. Tentukan berapa cara untuk membentuk panitia yang beranggotakan 5 orang yang dipilih dari 7 orang pria dan 5 orang wanita, jika di dalam panitia tersebut paling sedikit beranggotakan 2 wanita?

9. Perpustakaan prodi Informatika memiliki 3 jenis buku yaitu Kecerdasan Buatan, Matematika Diskrit dan Statistika. Masingmasing jenis buku memiliki paling sedikit 15 buah buku. Berapa banyak cara memilih 15 buah buku? 
10. Berapa banyak cara pengambilan 5 koin dari koin 100 an, 200 an dan 1000 an? 


\section{BAB 5}

\section{ALJABAR BOOLEAN}

\section{CAPAIAN PEMBELAJARAN:}

1. Mahasiswa mampu memahami konsep aljabar Boolean

2. Mahasiswa mampu mengaplikasikan aljabar Boolean 
Aljabar Boolean merupakan salah satu cabang matematika, dimana Boolean diambil dari nama penemunya yaitu George Boole seorang matematikawan dari Inggris. Perkembangan aljabar Boolean pada saat ini adalah aljabar ini sering digunakan dalam perancangan rangkaian elektronika dan sirkuit komputer.

\section{A. Definisi Aljabar Boolean}

Definisi 5.1. Misalkan $B$ adalah himpunan yang terdefinisi pada dua operator biner yaitu + dan . serta sebuah operator uner . Misalkan 0 dan 1 adalah dua elemen yang tak sama dari $B$, maka $<B,+$, . , ', 0, 1> disebut Aljabar Boolean jika untuk setiap $p, q, r \in$ $B$ berlaku aksioma (Postulat Huntington) berikut:
1. Identitas:
(i) $p+0=a$

(ii) $p \cdot 1=a$

3. Komutatif :

(i) $p+q=q+p$

(ii) $p \cdot q=q \cdot p$

4. Distributif : $\quad$ (i) $p \cdot(q+r)=(p \cdot q)+(p \cdot r)$

(ii) $p+(q \cdot r)=(p+q) \cdot(p+r)$

5. Komplemen ${ }^{1}$ :

(i) $p+p^{\prime}=1$

(ii) $p \cdot p^{\prime}=0$

Elemen 0 dan 1 adalam dua elemen yang unik, elemen 0 disebut zero dan elemen 1 disebut unit. Dua operator biner yaitu + disebut operator penjumlahan dan . disebut operator perkalian. Sedangankan operator uner ' disebut juga dengan operator komplemen.

\section{Contoh 5.1}

Diketahui $A=\{1,2,3,4,5,6,10,12,15,20,30,60\}$ adalah faktor dari 60. Buktikan A merupakan aljabar Boolean!

Penyelesaian:

Misalkan didefinisikan:

$$
\begin{aligned}
a+b & =\operatorname{KPK}(a, b) \\
a \cdot b & =\operatorname{FPB}(a, b) \\
a^{\prime} \quad & =60 / a
\end{aligned}
$$


dengan menggunakan definisi 5.1 diperoleh:

1. Identitas berlaku:

(i)

$$
a+b=\operatorname{KPK}(a, 1)=a
$$

(ii)

$$
a \cdot b=F P B(a, 70)=a
$$

2. Komutatif berlaku :

(i)

$$
a+b=b+a=\operatorname{KPK}(a, b)
$$

(ii)

$$
a \cdot b=b \cdot a=\operatorname{FPB}(a, b)
$$

3. Distributif berlaku karena:

(i) $6 \cdot(4+10)=\operatorname{FPB}(6, \operatorname{KPK}(4,10))=\operatorname{FPB}(6,2)=2$

$(6.4)+(6.10)=\operatorname{KPK}(\operatorname{FPB}(6,4), \operatorname{FPB}(6,10))=\operatorname{KPK}(2,2)=2$

(ii) $6+(4.10)=\operatorname{KPK}(6, \operatorname{FPB}(4,10))=\operatorname{KPK}(6,2)=6$ $(6+4) \cdot(6+10)=\operatorname{FPB}(\operatorname{KPK}(6,4), \operatorname{KPK}(6,10))=\mathrm{FPB}(6,30)=6$

4. Komplemen berlaku:

(i)

$$
a+a^{\prime}=\operatorname{KPK}(a, 60 / a)=60
$$

$$
a \cdot a^{\prime}=\operatorname{FPB}(a, 60 / a)=1
$$

Ke empat aksioma Aljabar Boolean terpenuhi, maka $\mathrm{A}=$ $\{1,2,3,4,5,6,10,12,15,20,30,60\}$ yang terdefinisi pada operator + dan . serta operator komplemen' terbukti sebuah aljabar Boolean.

\section{B. Aljabar Boolean Dua Nilai}

Definisi 5.2. Ajlabar Boolean dua nilai didefinisikan pada sebuah himpunan $B$ dengan dua elemen 0 dan 1 yaitu $B=\{0,1\}$, operator biner + dan . serta operator uner '.

Tabel kebenaran aljabar Boolean dua nilai untuk operator biner dan operator uner ditunjukkan pada tabel 5.1 berikut.

Tabel 5.1 tabel kebenaran untuk operator biner dan operator uner

\begin{tabular}{|c|c|c|c|c|}
\hline$p$ & $Q$ & $p+q$ & $p \cdot q$ & $p^{\prime}$ \\
\hline 0 & 0 & 0 & 0 & 1 \\
\hline 0 & 1 & 1 & 0 & 1 \\
\hline 1 & 0 & 1 & 0 & 0 \\
\hline 1 & 1 & 1 & 1 & 0 \\
\hline
\end{tabular}


Untuk membuktikan bahwa $\mathrm{B}=\{0,1\}$ aljabar Boolean harus memenuhi empat aksioma (postulat Huntington) dengan menggunakan tabel kebenaran dua operator biner dan satu operator uner.

1. Identitas berlaku karena terlihat dalam tabel bahwa:
(i)
$0+1=1+0=1$
(ii)
$1.0=0.1=0$

2. Komutatif berlaku dapat dilihat pada tabel operator biner yang simetri

3. Distributif berlaku ditunjukan pada tabel 7.2 berikut:

Tabel 5.2

\begin{tabular}{|c|c|c|c|c|c|c|c|}
\hline$P$ & $Q$ & $R$ & $q+r$ & $p \cdot(q+r)$ & $p \cdot q$ & $p \cdot r$ & $(p . q)+(p . r)$ \\
\hline 0 & 0 & 0 & 0 & 0 & 0 & 0 & 0 \\
\hline 0 & 0 & 1 & 1 & 0 & 0 & 0 & 0 \\
\hline 0 & 1 & 0 & 1 & 0 & 0 & 0 & 0 \\
\hline 0 & 1 & 1 & 1 & 0 & 0 & 0 & 0 \\
\hline 1 & 0 & 0 & 0 & 0 & 0 & 0 & 0 \\
\hline 1 & 0 & 1 & 1 & 1 & 0 & 1 & 1 \\
\hline 1 & 1 & 0 & 1 & 1 & 1 & 0 & 1 \\
\hline 1 & 1 & 1 & 1 & 1 & 1 & 1 & 1 \\
\hline
\end{tabular}

(i) $\quad p \cdot(q+r)=(p \cdot q)+(p \cdot r)$ adalah benar

(ii) $\quad p+(q \cdot r)=(p+q) \cdot(p+r)$ benar juga

4. Komplemen berlaku karena tabel 5.2 terlihat bahwa: 
(i) $\mathrm{p}+\mathrm{p}^{\prime}=1$, karena $0+0^{\prime}=0+1=1$ dan $1+1^{\prime}=1+0=1$

(ii) $p \cdot p^{\prime}=0$, karena $0.0^{\prime}=0.1=0$ dan $1 \cdot 1^{\prime}=1 \cdot 0=0$

Karena $B=\{0,1\}$ memenuhi ke empat aksioma maka terbukti bahwa $B=\{0,1\}$ merupakan aljabar Boolean dengan operator biner + dan . serta operator komplemen.

\section{Ekspresi Boolean}

Definisi 5.3. Misalkan $(\mathrm{B},+, \cdot,, ', 0,1)$ adalah sebuah aljabar Boolean. Suatu ekspresi Boolean dalam $(B,+, \cdot$, ') dapat ditulis:

(i) Setiap elemen ada di himpunan B

(ii) setiap peubah

(iii) Jika $\mathrm{e}_{1}$ dan $\mathrm{e}_{2}$ adalah ekspresi Boolean, maka $\mathrm{e}_{1}+\mathrm{e}_{2}, \mathrm{e}_{1} \cdot \mathrm{e}_{2}$, $\mathrm{e}_{1}{ }^{\prime}$ adalah ekspresi dari Boolean

Contoh 5.2 : Tentukan hasil evaluasi ekspresi Boolean berikut:

$$
a^{\prime}+(b \cdot c)
$$

Penyelesaian:

Misalkan $\mathrm{a}=0, \mathrm{~b}=1$ dan $\mathrm{c}=0$, maka hasil evaluasi ekspresi

$$
0^{\prime}+(1.0)=1 \cdot 0=0
$$

Dua ekspresi Boolean dikatakan ekivalen (di lambangkan dengan '=') jika keduanya bernilai sama untuk setiap nilainilai pada $n$ peubah dapat ditunjukkan dengan menggunakan tabel kebenaran.

\section{Contoh 5.3 :}

Tunjukkan bahwa $p q^{\prime}+q=p+q$.

Penyelesaian:

Untuk membuktikan $p q^{\prime}+q=p+q$ dengan menggunakan tabel kebenaran berikut.

Tabel 5.3

\begin{tabular}{|l|l|l|l|l|l|}
\hline$p$ & $q$ & $q^{\prime}$ & $p q^{\prime}$ & $p q^{\prime}+q$ & $p+q$ \\
\hline
\end{tabular}




\begin{tabular}{|l|l|l|l|l|l|}
\hline 0 & 0 & 1 & 0 & 0 & 0 \\
\hline 0 & 1 & 0 & 0 & 1 & 1 \\
\hline 1 & 0 & 1 & 1 & 1 & 1 \\
\hline 1 & 1 & 0 & 0 & 1 & 1 \\
\hline
\end{tabular}

Karena nilai-nilai pada kolom $p q^{\prime}+q$ sama dengan $p+q$, maka $p q^{\prime}+q=p+q$ benar.

Tanda titik (·) dapat hilang dari penulisan ekpresi Boolean, sehingga aksioma distributif dapat ditulis:

(i) $p(q+r)=p q+p r$

(ii) $p+q r=(p+q)(p+r)$

Kecuali tidak berlaku pada penulisan di bawah ini:

(iii) $\mathrm{p} \cdot 0$, bukan $\mathrm{p} 0$

\section{Prinsip Dualitas}

Definisi 5.4. Kesamaan (identity) dalam aljabar Boolean yang melibatkan operator,$+ \cdot$, dan komplemen dimisalkan $\mathrm{S}$, maka jika pertanyaan $\mathrm{S}^{*}$ diperoleh dari $\mathrm{S}$ dengan cara mengganti

$$
\begin{aligned}
& \text { dengan + } \\
& + \text { dengan } \\
& 0 \text { dengan } 1 \\
& 1 \text { dengan } 0
\end{aligned}
$$

Serta tidak mengganti operator komplemen, maka kesamaan $S^{*}$ juga bernilai benar. Dengan kata lain $S^{*}$ sebagai dual dari S.

\section{Contoh 5.4:}

Tentukan dualitas dari:
a. $p \cdot 1=p$
b. $(p+0)+\left(p^{\prime} .1\right)=1$
c. $(p \cdot q)+(p \cdot r)=p(q+r)$
Penyelesaian:
a. $p+0=p$
b. $(p \cdot 1) \cdot\left(p^{\prime}+0\right)=0$
c. $(p+q) \cdot(p+r)=p+(q r)$ 


\section{E. Hukum-hukum Aljabar Boolean}

Hukum-hukum aljabar Boolean ini didasarkan pada hukumhukum aljabar pada himpunan.

\section{Tabel 5.4 Hukum-hukum aljabar Booelan}

\begin{tabular}{|c|c|c|}
\hline 1. & Hukum Identitas & $\begin{array}{l}\text { - } p+0=a \\
\text { - } p \cdot 1=p\end{array}$ \\
\hline 2. & Hukum Idempoten & $\begin{array}{ll}\text { i. } & p+p=p \\
\text { ii. } & p \cdot p=p\end{array}$ \\
\hline 3. & Hukum Komplemen & $\begin{array}{ll}\text { i. } & p+p^{\prime}=1 \\
\text { ii. } & p p^{\prime}=0\end{array}$ \\
\hline 4. & Hukum Dominasi & $\begin{array}{ll}\text { i. } & p \cdot 0=0 \\
\text { ii. } & p+1=1\end{array}$ \\
\hline 5. & Hukum Involusi & i. $\quad\left(p^{\prime}\right)^{\prime}=p$ \\
\hline 6. & Hukum Penyerapan & $\begin{array}{ll}\text { i. } & p+p q=p \\
\text { ii. } & p(p+q)=p\end{array}$ \\
\hline 7. & Hukum Komutatif & $\begin{array}{ll}\text { i. } & p+q=q+p \\
\text { ii. } & p q=q p\end{array}$ \\
\hline 8. & Hukum Asosiatif & $\begin{array}{ll}\text { i. } & p+(q+r)=(p+q)+r \\
\text { ii. } & p(q r)=(p q) r\end{array}$ \\
\hline 9. & Hukum Distributif & $\begin{array}{ll}\text { i. } & p+(q r)=(p+q) \cdot(p+r) \\
\text { ii. } & p(q+r)=(p q)+(p r)\end{array}$ \\
\hline 10. & Hukum De Morgan & $\begin{array}{ll}\text { i. } & (p+q)^{\prime}=p^{\prime} q^{\prime} \\
\text { ii. } & (p q)^{\prime}=p^{\prime}+q^{\prime}\end{array}$ \\
\hline 11. & Hukum 0/1 & $\begin{array}{ll}\text { i. } \quad 0^{\prime}=1 \\
\text { ii. } \quad 1^{\prime}=0\end{array}$ \\
\hline
\end{tabular}

\section{Contoh 5.5:}

Tunjukkan bahwa $a b^{\prime}+b=a+b$ dan $b\left(a+b^{\prime}\right)=$ ba adalah benar dengan menggunakan hukum-hukum aljabar 
Boolean

Penyelesaian:

(i)

$\begin{aligned} a b^{\prime}+b & =a b^{\prime}+(b a+b) & & \text { Hukum penyerapan } \\ & =\left(a b^{\prime}+b a\right)+b & & \text { Hukum asosiatif } \\ & =a\left(b^{\prime}+b\right)+b & & \text { Hukum distributif } \\ & =a \cdot 1+b & & \text { Hukum Komplemen } \\ & =a+b & & \text { Hukum Identitas } \\ b\left(a+b^{\prime}\right) & =b a+b b^{\prime} & & \text { Hukum Distributif } \\ & =b a+0 & & \text { Hukum Komplemen } \\ & =b a & & \text { Hukum identitas } \\ & =a b & & \text { Hukum asosiatif }\end{aligned}$

Terbukti

\section{F. Fungsi Boolean}

Definisi 5.5. Fungsi Boolean adalah suatu pemetaan dari $\mathrm{B}^{\mathrm{n}}$ ke $\mathrm{B}$ dengan ekspresi Boolean, dapat ditulis sebagai berikut:

$$
f: B^{n} \rightarrow B
$$

dengan $B^{n}$ adalah himpunan yang beranggotakan pasangan terurut ganda $-n$ dalam daerah asal $B$.

Setiap ekspresi Boolean merupakan fungsi Boolean

\section{Contoh 5.6 :}

Diketahui fungsi Boolean $f(x, y, z)=x y z+x^{\prime} y+y^{\prime} z$

Petakan fungsi $f$ yaitu nilai- nilai pasangan terurut ganda-3 $(x, y, z)$ ke himpunan $\{0,1\}$

Penyelesaian :

$(x, y, z)=(1,0,1)$ dengan $\mathrm{x}=1, \mathrm{y}=0, \mathrm{z}=1$ sehingga diperoleh:

$f(1,0,1)=1 \cdot 0 \cdot 1+1^{\prime} \cdot 0+0^{\prime} \cdot 1=0+0+1=1$

\section{G. Penjumlahan dan Perkalian Dua Fungsi}

Definisi5.6. Misalkan ada dua buah fungsi Boolean yaitu $f$ dan $g$ dengan $n$ peubah, maka penjumlahan $f+g$ dapat 
ditulis sebagai berikut:

$(f+g)\left(x_{1}+x_{2}+\cdots+x_{n}\right)=f\left(x_{1}+x_{2}+\cdots+x_{n}\right)+g\left(x_{1}+x_{2}+\cdots+x_{n}\right)$

Sedangkan untuk perkalian $f . g$ ditulis sebagai berikut:

$$
(f \cdot g)\left(x_{1}+x_{2}+\cdots+x_{n}\right)=f\left(x_{1}+x_{2}+\cdots+x_{n}\right) \cdot g\left(x_{1}+x_{2}+\cdots+x_{n}\right)
$$

Contoh 5.7:

Diketahui fungsi $f(x, y)=x y^{\prime}+y$ dan $g(x, y)=x^{\prime}+y^{\prime}$

Tentukan :

a. $h(x, y)=f+g$

b. $\quad i(x, y)=f \cdot g$

Penyelesaian:
a. $h(x, y)=f+g=x y^{\prime}+y+x^{\prime}+y^{\prime}$
$=x y^{\prime}+x^{\prime}+y+y^{\prime}$
$=x y^{\prime}+x^{\prime}+1$
$=x y^{\prime}+x^{\prime}$
b. $\quad i(x, y)=f \cdot g=\left(x y^{\prime}+y\right)\left(x^{\prime}+y^{\prime}\right)$

\section{H. Aplikasi Aljabar Boolean}

Aplikasi aljabar Boolean sangat luas di bidang keteknikan yaitu antara lain di bidang elektronika tentang jaringan pensaklaran dan di bidang komputer yaitu rangkaian digital.

Dua aplikasi aljabar Boolean dibahas berikut ini;:

\section{Jaringan Pensaklaran}

Saklar merupakan suatu objek yang memiliki dua buah status yaitu buka dan tutup. Pada rangkaian listrik seri misal ada dua buah saklar yaitu A dan B, lampu hanya menyala jika A dan $B$ ditutup. Ekspresi Boolean yang menggambarkan hubungan seri tersebut dinyatakan sebagai AB. Sedangkan pada rangkaian listrik paralel, lampu hanya menyala jika salah satu dari A atau B ditutup. Dalam ekspresi Boolean dinyatakan $A+B$ untuk rangkaian listrik paralel.

\section{Sirkuit Elektronik}

Komputer dan peralatan elektronika dirangkai dari sejumlah rangkaian atau sirkuit. Sirkuit ini menerima masukan dan 
keluaran yaitu berupa aliran-aliran listrik yang didefinisikan sebagai 0 dan 1 . Aljabar Boolean adalah sebagai suatu alat untuk memodelkan sirkuit elektronik. Sirkuit memiliki elemen dasar yang disebut gerbang (gate). Masing-masing gerbang mewakili sebuah ekspresi Boolean yaitu AND, OR dan NOT.

\section{KESIMPULAN}

1. Misalkan B adalah himpunan yang terdefinisi pada dua operator biner yaitu + dan . serta sebuah operator uner '. Misalkan 0 dan 1 adalah dua elemen yang tak sama dari $B$, maka $\langle B,+, .$, ' $, 0,1\rangle$ disebut Aljabar Boolean jika untuk setiap $p, q, r \in B$ berlaku aksioma (Postulat Huntington)

2. Ajlabar Boolean dua nilai didefinisikan pada sebuah himpunan $B$ dengan dua elemen 0 dan 1 yaitu $B=\{0,1\}$, operator biner + dan . serta operator uner '.

3. Misalkan $(B,+, \cdot, ', 0,1)$ adalah sebuah aljabar Boolean. Suatu ekspresi Boolean dalam $(B,+, \cdot, ')$ dapat ditulis:

(i) Setiap elemen ada di himpunan $B$

(ii) setiap peubah

(iii) Jika $e_{1}$ dan $e_{2}$ adalah ekspresi Boolean, maka $e_{1}+e_{2}, e_{1} \cdot e_{2}$, $\mathrm{e}_{1}{ }^{\prime}$ adalah ekspresi dari Boolean

4. Kesamaan (identity) dalam aljabar Boolean yang melibatkan operator + , · , dan komplemen dimisalkan $\mathrm{S}$, maka jika pertanyaan $S^{*}$ diperoleh dari $S$ dengan cara mengganti :

$$
\begin{aligned}
& \cdot \text { dengan + } \\
& + \text { dengan } \\
& 0 \text { dengan } 1 \\
& 1 \text { dengan } 0
\end{aligned}
$$

5. Hukum-hukum aljabar Boolean ini didasarkan pada hukumhukum aljabar pada himpunan. 
6. Fungsi Boolean adalah suatu pemetaan dari $B^{n}$ ke $B$ dengan ekspresi Boolean, dapat ditulis $f: B^{n} \rightarrow B$ dengan $B^{n}$ adalah himpunan yang beranggotakan pasangan terurut ganda $-n$ dalam daerah asal B.

7. Misalkan ada dua buah fungsi Boolean yaitu $f$ dan $g$ dengan $n$ peubah, maka penjumlahan $f+g$ dapat ditulis sebagai berikut: $(f+g)\left(x_{1}+x_{2}+\cdots+x_{n}\right)=f\left(x_{1}+x_{2}+\cdots+x_{n}\right)+g\left(x_{1}+x_{2}+\cdots+x_{n}\right)$

8. Perkalian $f . g$ ditulis sebagai berikut:

$$
(f \cdot g)\left(x_{1}+x_{2}+\cdots+x_{n}\right)=f\left(x_{1}+x_{2}+\cdots+x_{n}\right) \cdot g\left(x_{1}+x_{2}+\cdots+x_{n}\right)
$$

9. Aplikasi aljabar Boolean sangat luas di bidang keteknikan yaitu antara lain di bidang elektronika tentang jaringan pensaklaran dan di bidang komputer yaitu rangkaian digital.

\section{LATIHAN SOAL}

1. Diketahui $B=\{1,2,4,5,10,20,25,50,100\}$ adalah faktor dari 100. Buktikan B merupakan aljabar Boolean!

2. Buktikan dengan tabel kebenaran aljabar Boolean bahwa $a+(b+c)=(a+b)+c$ dan $a \cdot(b \cdot c)=(a \cdot b) \cdot c$

3. Diketahui fungsi:

$$
f(x, y)=x^{\prime} y^{\prime}+y+x \operatorname{dan} g(x, y)=x y+x^{\prime}
$$

Tentukan :

$$
h(x, y)=f+g \text { dan } i(x, y)=f \cdot g
$$

4. Diketahui fungsi Boolean $f(x, y, z)=x^{\prime} y+x y z^{\prime}+x^{\prime} y^{\prime} z$

Petakan fungsi $f$ yaitu nilai-nilai pasangan terurut ganda-3 $(x, y, z)$ ke himpunan $\{0,1\}$ !

5. Buktikan dengan menggunakan hukum-hukum aljabar Boolean sifat distributif:

i. $\quad p+(q r)=(p+q) \cdot(p+r)$

ii. $\quad p(q+r)=(p q)+(p r)$ 


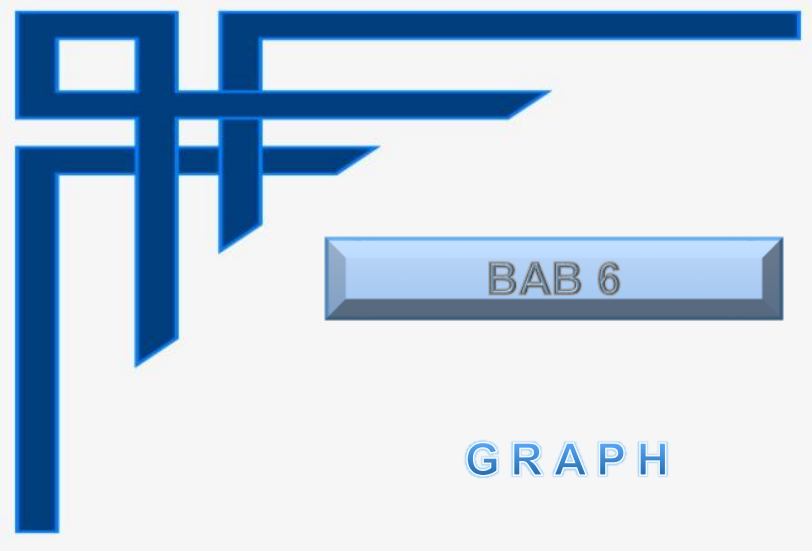

CAPAIAN PEMBELAJARAN:

1. Mahasiswa mampu memahami konsep Graph

2. Mahasiswa mampu mengaplikasikan Graph 
Teori Graph adalah salah satu cabang ilmu matematika yang pokok bahasannya tentang presentasi objek-objek diskrit dan hubungan antara objek-objek tersebut.

A. Definisi Graph

Definisi 6.1. Graph $G$ merupakan pasangan himpunan $(V$, E) dinotasikan $G=(V, E)$, dimana $V$ merupakan himpunan tak kosong dari simpul-simpul (vertices), misalkan $V=\left\{V_{1}, V_{2}, \ldots, V_{n}\right\}$ dan $E$ adalah himpunan sisisisi (edges) yang menghubungkan sepasang simpul, misalkan $E=\left\{e_{1}, e_{2}, \ldots, e_{n}\right\}$.

\section{Contoh 6.1:}

Tentukan himpunan $V$ dan himpunan sisi $E$ dari graph berikut:

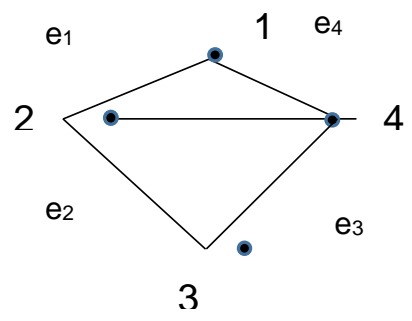

$\mathrm{G}_{1}$

\section{Gambar 6.1}

Penyelesaian:

$$
\begin{aligned}
V & =\{1,2,3,4\} \\
E & =\{(1,2),(1,3),(2,3),(2,4),(3,4)\} \\
& =\left\{e_{1}, e_{2}, e_{3}, e_{4}, e_{5}\right\}
\end{aligned}
$$

Pada contoh di atas tidak gelang atau loop yaitu sisi yang berawal dan berakhir di simpul yang sama.

B. Jenis-jenis Graph

Graph berdasarkan ada tidaknya gelang atau sisi ganda dapat dibedakan menjadi dua jenis yaitu: 
1. Graph sederhana

Graph sederhana adalah graph yang tidak memiliki gelang maupun sisi ganda.

2. Graph tak sederhana

Graph tak sederhana adalah yang memiliki sisi ganda atau gelang.

Graph berdasarkan orientasi arah pada sisi digolongkan menjadi dua jenis yaitu:

1. Graph tak berarah

Graph tak berararh adalah graph yang sisinya tidak mempunyai orientasi. Pada graph tak berarah, urutan pasangan simpul tidak diperhatikan.

2. Graph Berarah

Graph berarah adalah graph yang setiap sisinya memliki orientasi arah. Sisi yang memiliki arah disebut juga dengan busur.

\section{Contoh 6.2:}

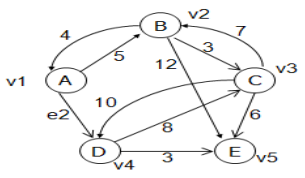

Directed graph

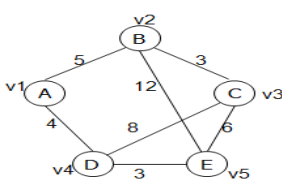

Undirected graph

Sumber:

\section{Gambar 6.2}

https://aerfanpratomo95.wordpress.com/2014/06/26/graph/

\section{Terminologi Dasar Graph}

Perhatikan gambar 


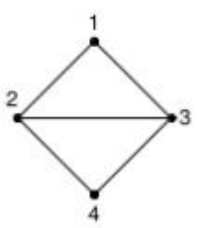

$G_{1}$

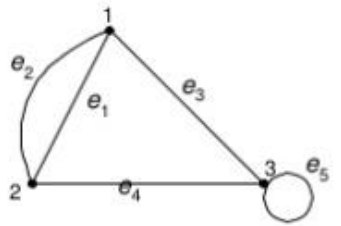

$G_{2}$

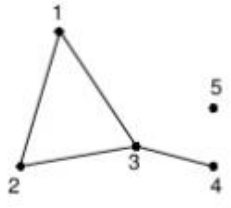

$G_{3}$

\section{Gambar 6.3}

1. Bertetangga

Definisi 6.2. Dua buah simpul pada graph tak berarah disebut bertetangga jika keduanya terhubung langsung dengan sebuah sisi.

\section{Contoh 6.3:}

Pada gambar $6.3 G_{1}$ simpul 1 bertetangga dengan simpul 2 dan 3, tetapi simpul 1 tidak bertetangga dengan simpul 4 .

2. Bersisian

Definisi 6.3. Sisi e dikatakan bersisian dengan simpul $u$ dan simpul $v$ untuk sembarang sisi $e=(u, v)$

\section{Contoh 6.4:}

Pada gambar $6.3 G_{1}$ sisi $(2,3)$ bersisian dengan simpul 2 dan simpul 3, sisi $(2,4)$ bersisian dengan simpul 2 dan 4 , tetapi sisi $(1,2)$ tidak bersisian dengan simpul 4.

3. Simpul Terpencil

Definisi 6.4. Simpul terpencil adalah simpul yang tidak memiliki sisi yang bersisian dengannya.

\section{Contoh 6.5:}

Pada gambar $6.3 G_{3}$, simpul 5 adalah simpul terpencil.

4. Graph Kosong (Null Graph)

Definisi 6.5. Graph kosong adalah graph yang himpunan sisinya merupakan himpunan kosong. 
Graph kosong dinotasikan $\mathrm{N}_{\mathrm{n}}$

\section{Contoh 6.6:}

\section{Gambar 6.4 Graph Kosong}

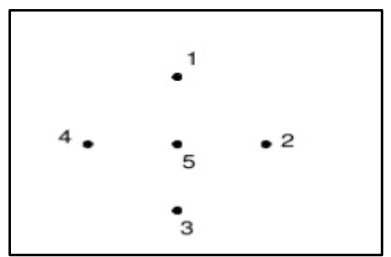

5. Derajat

Definisi 6.6. Jumlah sisi yang bersisian dengan simpul adalah derajat suatu simpul pada graph tak berarah.

Dinotasikan: $d(v)=$ derajat simpul $v$

\section{Contoh 6.7:}

Pada gambar $6.3 G_{1}$

$d(1)=d(4)=2$

$d(2)=d(3)=3$

Definisi 6.7. Pada graph berarah, derajat simpul $v$ didefinisikan dengan $d_{\text {in }}(v)$ dan $d_{\text {out }}(v)$, dimana:

$d_{\text {in }}(v) \quad=$ derajat masuk =jumlah busur yang masuk ke simpul $v$

$d_{\text {out }}(v) \quad=$ derajat keluar

$=$ jumlah busur yang keluar dari simpul $v$

dan $d(v)=d_{\text {in }}(v)+d_{\text {out }}(v)$

\section{Contoh 6.8:}




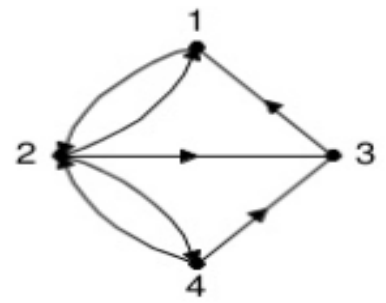

\section{Gambar 6.5}

Perhatikan graph berarah tersebut:

Derajat setiap simpul adalah

$\begin{array}{ll}d_{\text {in }}(1)=2 & d_{\text {out }}(1)=1 \\ d_{\text {in }}(2)=2 & d_{\text {out }}(2)=3 \\ d_{\text {in }}(3)=2 & d_{\text {out }}(3)=1 \\ d_{\text {in }}(4)=1 & d_{\text {out }}(4)=2\end{array}$

6. Lintasan (Path)

Definisi 6.8. Lintasan yang panjangnya n dari simpul $v_{0}$ ke $v_{n}$ dalam graph $G$ adalah barisan berselang seling simpul-simpul dan sisi-sisi yang dapat ditulis $v_{0}, e_{1}, v_{1}, e_{2}, \ldots, v_{n-1}, e_{n}, v_{n}$ sedemikian hingga $e_{1}=\left(v_{0}, v_{1}\right), e_{2}=\left(v_{1}, v_{2}\right), \ldots, e_{n}=\left(v_{n-1}, v_{n}\right)$ adalah sisi-sisi dari graph.

Lintasan jika semua simpulnya berbeda disebut lintasan sederhana.

Lintasan tertutup adalah lintasan yang berawal dan berakhir pada simpul yang sama.

Sedangkan lintasan terbuka adalah lintasan yang tidak berawal dan berakhir pada simpul yang sama.

\section{Contoh 6.9:}

Pada gambar $6.3 G_{1}$

Lintasan 1,2,4,3 : lintasan sederhana dan terbuka 
Lintasan 1,2,4,3,1 : lintasan sederhana dan tertutup Lintasan 1,2,4,3,2 : bukan lintasan sederhana tetapi terbuka

7. Sirkuit

Definisi 6.9. Lintasan yang berawal dan berakhir pada simpul yang sama disebut sirkuit.

Sirkuit dikatakan sederhana jika setiap sisi yang dilalui berbeda

Contoh 6.10:

Pada gambar 6.3 G1

1,2,3,1 adalah sirkuit sederhana sedangkan 1,2,4,3,2,1 bukan sirkuit sederhana karena sisi $(1,2)$ dilewati dua kali.

8. Cut set

Definisi 6.10. Cut-set dari suatu graf terhubung $G$ adalah himpunan sisi yang jika dibuang dari $G$ menyebabkan $G$ tidak terhubung. Jadi, cut-set selalu menghasilkan dua buah subgraf .

Pada graf di bawah, $\{(1,4),(1,5),(2,3),(2,4)\}$ adalah cutset. Terdapat banyak cut-set pada sebuah graf terhubung. Himpunan $\{(1,5),(4,5)\}$ juga adalah cut-set, $\{(1,4),(1,5)$, $(1,2)\}$ adalah cut-set, $\{(5,6)\}$ juga cut-set, tetapi $\{(1,4),(1,5)$, $(4,5)\}$ bukan cut-set sebab himpunan bagiannya, $\{(1,5)$, $(4,5)\}$ adalah cut-set.
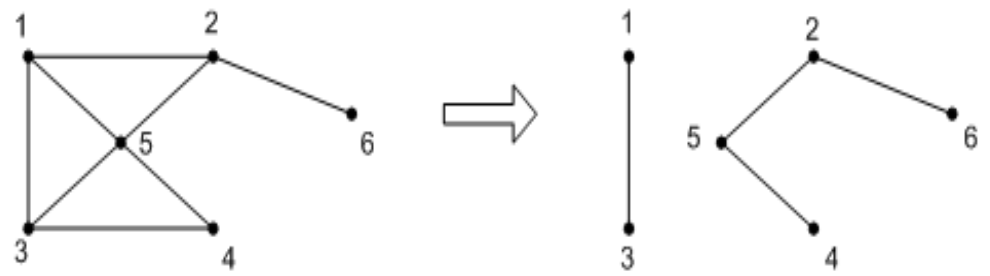

Gambar 6.6 Graph cut set 


\section{Lintasan dan Sirkuit Euler}

Definisi 6.10. Lintasan yang melalui setiap sisi di dalam graph tepat satu kali disebut lintasan Euler. Sedangkan sirkuit Euler adalah sirkuit yang melewati setiap sisi tepat satu kali.

\section{Contoh 6.11:}

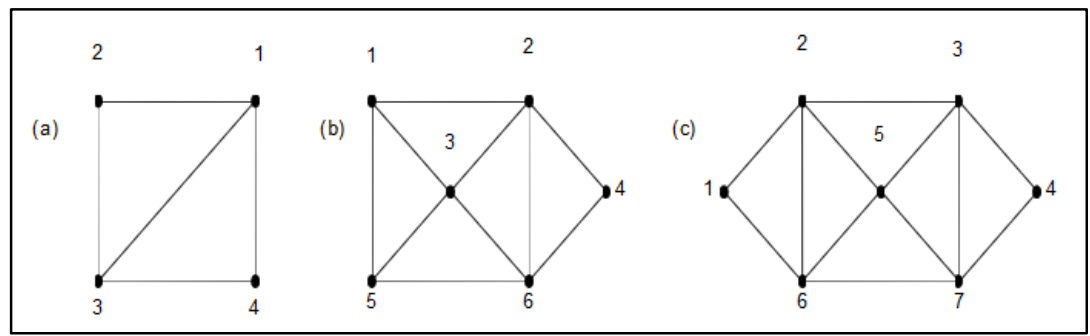

Gambar 6.7 Lintasan Euler dan Sirkuit Euler

Perhatikan gambar 6.6.

Lintasan Euler pada graph $(a)=3,1,2,3,4,1$

Lintasan Euler pada graph (b) = 1,2,4,6,2,3,6,5,1,3

Sirkuit Euler pada graph (c) $=1,2,3,4,7,3,5,7,6,5,2,6,1$

\section{E. Lintasan dan Sirkuit Hamilton}

Definisi 6.11. Lintasan Hamilton adalah lintasan yang melewati tiap simpul di dalam graph tepat satu kali. Sedangkan sirkuit Hamilton adalah sirkuit yang melewati tiap simpul di dalam graph tepat satu kali, kecuali simpul asal yang dilewati dua kali.

\section{F. Lintasan Terpendek}

Lintasan terpendek menggunakan graph berbobot yaitu graph yang setiap diberi nilai atau bobot. Bobot pada sisi graph menunjukkan jarak antar kota, waktu pengiriman pesan, biaya perjalanan dan sebagainya.

Algoritma lintasan terpendek yang sering digunakan adalah algoritma Dijkstra. Penerapan algoritma ini digunakan pada 
jaringan komputer. Jaringan komputer dapat direpresentasikan sebagai sebuah graph terhubung dengan setiap simpul yang disebut router.

\section{G. Pewarnaan Graph}

Definisi 6.12. Pewarnaan simpul adalah pemberian warna pada simpul-simpul di dalam graph sedemikian hingga setiap dua simpul bertetangga memiliki warna yang berbeda.

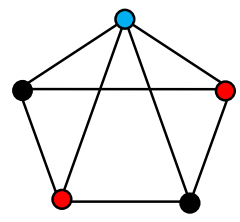

(a)

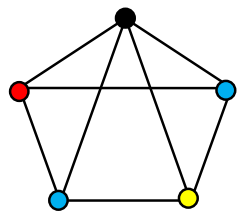

(b)

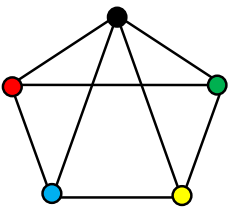

(c)

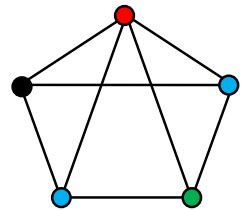

(d)

Gambar 6.8 Pewarnaan simpul pada graph

Bilangan kromatik graf pada Gambar 1 ada sejumlah 4 warna. Bilangan kromatik dari graf $G$ dinyatakan dengan $\lambda(G)$ adalah jumlah warna minimal yang digunakan untuk mewarnai simpul yang bertetangga (adjacent) diwarnai dengan warna yang berbeda. Sehingga pada gambar diatas $\lambda(G)=4$.

Graph memberikan kontribusi yang besar terhadap pemecahan permasalahan pewarnaan graph dalam menentukan jumlah minimum warna yang dibutuhkan untuk mewarnai sembarang peta.

Definisi 6.13. Pewarnaan sisi didefinisikan misal $G$ adalah graf sederhana, pewarnaan sisi- $k$ untuk $G$ adalah pemberian $k$ warna pada sisi sisi $G$ sedemikian hingga setiap dua sisi yang bertemu pada simpul yang sama mendapatkan warna yang berbeda (Wilson, 1990). 
Definisi 6.14. Pewarnaan wilayah (region) adalah memberikan warna pada bidang sehingga tidak ada bidang yang bertetangga mempunyai warna yang sama.

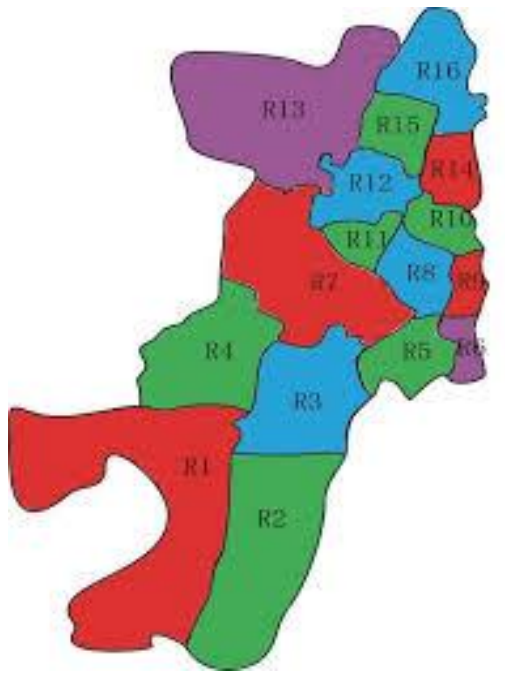

Gambar 6.9. Pewarnaan Wilayah

Definisi 6.15. Jumlah warna minimum yang diperlukan untuk mewarnai suatu simpul dalam suatu graf $G$ disebut dengan bilangan kromatik dari graf $G$, yang dinotasikan dengan $\chi(G)$. Suatu graf $G$ yang mempunyai bilangan kromatik $k$ dilambangkan dengan $\chi(G)=k$. (Gross, 2006).

\section{Prinsip Untuk Menghitung Bilangan Kromatik}

Beberapa prinsip dasar dalam perhitungan bilangan kromatik yaitu menemukan nilai batas atas dan batas bawah. Terdapat pendekatan langsung yang meliputi dua langkah (Gross, 2006), yaitu

- Batas atas (Upper Bound) dinotasikan $\chi(G) \leq k$, dengan $k$ menunjukkan $k$-warna dari $G$.

- Batas bawah (Lower Bound) dinotasikan $\chi(G) \geq k$, dengan menemukan subgraf yang memenuhi $k$-warna dari $G$. 


\section{KESIMPULAN}

1. Graph $G$ merupakan pasangan himpunan $(V, E)$ dinotasikan $G=$ $(V, E)$, dimana $V$ merupakan himpunan tak kosong dari simpul-simpul (vertices), misalkan $V=\left\{v_{1}, v_{2}, \ldots, v_{n}\right\}$ dan $E$ adalah himpunan sisi-sisi (edges) yang menghubungkan sepasang simpul, misalkan $E=\left\{e_{1}, e_{2}, \ldots, e_{n}\right\}$.

2. Graph berdasarkan ada tidaknya gelang atau sisi ganda dapat dibedakan menjadi dua jenis yaitu graph sederhana dan graph tak sederhana.

3. Graph berdasarkan orientasi arah pada sisi digolongkan menjadi dua jenis yaitu graph tak berarah dan graph berarah

4. Dua buah simpul pada graph tak berarah disebut bertetangga jika keduanya terhubung langsung dengan sebuah sisi.

5. Graph kosong adalah graph yang himpunan sisinya merupakan himpunan kosong.

6. Jumlah sisi yang bersisian dengan simpul adalah derajat suatu simpul pada graph tak berarah.

7. Pada graph berarah, derajat simpul $v$ didefinisikan dengan $d_{i n}(v)$ dan $d_{\text {out }}(v)$

8. Lintasan jika semua simpulnya berbeda disebut lintasan sederhana.

9. Sirkuit dikatakan sederhana jika setiap sisi yang dilalui berbeda

10. Cut-set dari suatu graf terhubung $G$ adalah himpunan sisi yang jika dibuang dari $G$ menyebabkan $G$ tidak terhubung.

11. Lintasan terpendek menggunakan graph berbobot yaitu graph yang setiap diberi nilai atau bobot.

12. Pewarnaan simpul adalah pemberian warna pada simpul-simpul di dalam graph sedemikian hingga setiap dua simpul bertetangga memiliki warna yang berbeda.

13. Pewarnaan sisi didefinisikan misal $G$ adalah graf sederhana, pewarnaan sisi- $k$ untuk $G$ adalah pemberian $k$ warna pada sisi 
sisi $G$ sedemikian hingga setiap dua sisi yang bertemu pada simpul yang sama mendapatkan warna yang berbeda

14. Pewarnaan wilayah (region) adalah memberikan warna pada bidang sehingga tidak ada bidang yang bertetangga mempunyai warna yang sama.

15. Jumlah warna minimum yang diperlukan untuk mewarnai suatu simpul dalam suatu graf $G$ disebut dengan bilangan kromatik dari graf $G$, yang dinotasikan dengan $\chi(G)$. 


\section{LATIHAN SOAL}

1. Pada suatu pesta, terdapat 8 orang saling berjabat tangan. Setiap orang berjabat tangan hanya satu kali dengan orang lain. Tentukan jumlah jabat tangan yang terjadi dengan memodelkan dalam graph!

2. Sebuah graph akan dibentuk dari 20 sebuah sisi. Berapa jumlah maksimum simpul yang dapat dibentuk dari 20 sisi tersebut dalam graph sederhana?

3. Berapa jumlah minimum kabel yang dibutuhkan jika ada $n$ buah komputer yang akan dihubungkan dengan sejumlah kabel baik langsung maupun terhubung melalui komputer lainnya?

4. Pada kejuaran sepakbola piala Presiden, terdapat 8 tim sepakbola yang mengikuti. Pertandingan menggunakan sistem setiap tim hanya bertemu satu kali dengan tim lainnya. Misalkan ke 8 tim tersebut dinamai $A, B, C, D, E, F, G, H$. Gambarkan graph berarah yang mempresentasikan satu set pertandingan!

5. Tentukan jumlah simpul pada graph sederhana jika memilki 15 buah sisi dan tiap sampul berderajat 2 ! 


\section{DAFTAR PUSTAKA}

Budayasa, I Ketut. 2008. Matematika Diskrit. Surabaya: Unesa University Press.

Jong, Jek Siang. 2009. Matematika Diskrit dan Aplikasinya pada IImu Komputer. Yogyakarta: Andi.

Munir, Rinaldi. 2005. Matematika Diskrit Revisi Kelima. Bandung: Informatika. 


\section{BIODATA PENULIS}

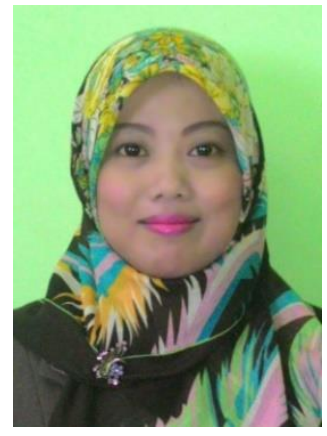

Novia Ariyanti, S.Si., M.Pd. lahir di Surabaya, 10 Nopember 1983. Lulus Sarjana Matematika Universitas Negeri Surabaya tahun 2007 dengan gelar S.Si. Penulis melanjutkan studi S2 di Prodi Pendidikan Matematika Program Pascasarjana Universitas Negeri Surabaya lulus tahun 2014 dengan gelar M.Pd. Karir pendidikan dan pengajaran dimulai tahun 2015 di fakultas

Teknik Prodi Informatika Universitas Muhammadiyah Sidoarjo. Selain pengajaran, penulis juga ikut berperan serta dalam kegiatan penelitian dan pengabdian. Penulis juga aktif dalam mengikuti kegiatan-kegiatan penunjang akademik seperti seminar, workshop/ lokakarya, pelatihan dan kegiatan akademik lainnya.

Nuril Lutvi Azizah, S.Si., M.Si. dilahirkan di Lumajang, 29 April 1989. Pada tahun 2011, penulis mendapatkan gelar Sarjana Sains Matematika dari Institut Teknologi Sepuluh Nopember Surabaya. Penulis melanjutkan studi S2 pada tahun yang sama yaitu tahun 2011 di Program Pascasarjana Matematika melalui beasiswa Freshgraduate dari Institut Teknologi Sepuluh Nopember Surabaya. Tahun 2013, penulis secara resmi mendapatkan gelar M.Si. Penulis mengawali karirnya sebagai Dosen tetap pada tahun 2015 di fakultas Teknik prodi Informatika Universitas Muhammadiyah Sidoarjo. Selain pendidikan dan pengajaran, penulis juga terlibat dalam penelitian dan pengabdian kepada masyarakat. Beberapa yang pernah dilakukan oleh penulis adalah tentang aplikasi matematika dalam bidang teknik dan penerapannya. 